\title{
Detrital zircon age and provenance constraints on late Paleozoic ice-sheet growth and dynamics in western and central Australia
}

Joe R. Martin ${ }^{1}$ $\S$, Jonathan Redfern ${ }^{1}$, Matthew S.A. Horstwood ${ }^{2}$, Arthur J. Mory ${ }^{3}$, Brian P.J. Williams ${ }^{4}$

${ }^{1}$ Basin Studies and Petroleum Geoscience, School of Earth, Atmospheric and Environmental Sciences, University of Manchester, M13 9PL, United Kingdom.

${ }^{2}$ NERC Isotope Geosciences Laboratory, British Geological Survey, Keyworth, NG12 5GG, United Kingdom.

${ }^{3}$ Department of Industry Regulation and Safety, Government of Western Australia, Mineral House, 100 Plain Street, East Perth, WA 6004, Australia.

${ }^{4}$ Department of Geology \& Petroleum Geology, University of Aberdeen, AB24 3UE, United Kingdom.

* Corresponding author: joe.martin@shell.com

$\S$ Current address: Shell Malaysia Ltd., Menara Shell, Jalan Tun Sambanthan 211, Kuala Lumpur, 50470, Malaysia. 


\begin{abstract}
$\mathrm{U}-\mathrm{Pb}$ dating and $\mathrm{Hf}$ isotope provenance analysis of detrital zircons from the glaciogenic Lower Permian Grant Group of the Canning Basin indicates sources principally from basement terranes in central Australia, with subordinate components from terranes to the south and north. Integrating this data with field outcrop and subsurface evidence for ice-sheets, including glacial valleys and striated pavements along the southern and northern margins of the basin, suggests that continental ice sheets extended over several Precambrian upland areas of western and central Australia during the late Paleozoic ice age (LPIA). The youngest zircons constrain the maximum age for contemporaneous ice sheet development to the Late Carboniferous (Kasimovian), whereas palynology provides a minimum age of Early Permian (Asselian-Sakmarian). Considering the palynological age of the Grant Group within the context of regional and global climate proxies, the main phase of continental ice sheet growth was possibly in the Ghzelian-Asselian. The presence of ice sheets older than Kasimovian in western and central Australia remains difficult to prove given a regional gap in deposition possibly covering the mid-Bashkirian to early Ghzelian within the main depocentres and even larger along basin margins, and the poor evidence for older Carboniferous glacial facies. There is also no evidence for extensive glacial facies younger than mid-Sakmarian in this region as opposed to eastern Australia where the youngest regional glacial phase was Guadalupian.
\end{abstract}

Keywords: late Paleozoic ice age; Canning Basin; Grant Group; Permian; zircon provenance; $\mathrm{U}-\mathrm{Pb}-\mathrm{Hf}$ 


\section{INTRODUCTION}

The record of the late Paleozoic ice age (LPIA) in Australia is extensive, with glaciogenic strata preserved in many basins across the continent (Crowell \& Frakes, 1975; Hambrey and Harland, 1981; Eyles, 1993; Jones and Fielding, 2004; Birgenheier et al., 2007; Mory et al., 2008; Isbell et al., 2012; Montanez \& Poulsen, 2013). The application of biostratigraphy, paleontology and SHRIMP U-Pb dating provide important constraints on the age and timing of events during the LPIA, thereby allowing significant advances in our understanding of this ice age (e.g. Foster and Waterhouse, 1998; Archbold, 1995, 1999; Archbold and Shi, 1995; Roberts et al., 1995, 1996; Fielding et al., 2008; Waterhouse \& Shi, 2013). Sedimentological studies also demonstrate that parts of the continent experienced intermittent glacial conditions from the mid-Carboniferous through to the Late Permian. At c. $65 \mathrm{Myr}$, this is possibly the longest-lived record of the LPIA in Gondwana (Jones et al., 2006; Eyles et al., 2006;

Birgenheier et al., 2007; Fielding et al., 2008). Stratigraphic data suggests the LPIA was most extensive during the Early Permian, with glaciogenic sediments of this age preserved in most Phanerozoic basins across the continent (e.g. Williams et al., 1987; Jones and Fielding, 2004; Fielding et al., 2008).

The majority of studies on the LPIA in Australia are on glacial successions that outcrop in eastern Australia whereas stratigraphic constraints on the evolution of the LPIA in western and central Australia are tenuous by comparison. This is despite, for example, the marine basins of Western Australia containing amongst the thickest glaciogenic successions in Gondwana (up to several km; Eyles et al., 2002, 2006; Mory et al., 2008). Within the context of these recent advances in the understanding of the LPIA in wider Australia, this paper presents new radiometric age constraints for the LPIA in western and central Australia based on uranium-lead (U-Pb) dating and lutetium-hafnium ( $\mathrm{Lu}-\mathrm{Hf})$ isotope geochemistry of detri- 
tal zircons from the Grant Group of the Canning Basin (Western Australia). This analysis links the glaciation's depositional and erosional records to sedimentological and stratigraphic interpretations of field outcrops and equivalent subsurface successions (Redfern, 1990; Martin, 2008; Mory et al., 2008; Al-Hinaai \& Redfern, 2015) to critically assess regional glaciation models for the LPIA in western and central Australia.

\section{GEOLOGICAL SETTING AND CANNING BASIN LPIA STRATIGRAPHIC OVER-} VIEW

During the LPIA, Australia was situated at mid to high latitudes in eastern Gondwana, with subduction of the paleo-Pacific along its eastern margin and rifting predating the break-up with India and Himalayan terranes along its western margin (Veevers and Tewari, 1995; Metcalfe, 1996, 2013; Betts et al., 2002; Veevers, 2004; Glen, 2005). At this time the intracratonic Canning Basin was flanked by Precambrian upland areas. In central Australia elevation and exhumation of the Arunta Inlier and Musgrave Block followed the Devonian-Carboniferous Alice Springs Orogeny and, to the south and north, the Pilbara-Yilgarn cratons and Kimberley region were also long-lived areas of positive basement relief (Fig. 1; Hand et al., 1999; Veevers, 2004, 2009, Buick et al., 2008). Sedimentological and paleontological evidence indicates marine incursions into the northern Canning Basin from the northwest in the Early Permian (Archbold, 1995, 1999; Archbold and Shi, 1995; Martin et al., 2007). There is also widespread evidence for Early Permian glacial conditions across Australia and Gondwana (e.g. Blatchford, 1927; Crowell \& Frakes, 1975; Crowe \& Turner, 1976; Redfern, 1990; Redfern \& Millward, 1994; Redfern \& Williams, 2002; Isbell et al., 2003; Jones and Fielding, 2004; Osterloff et al., 2004; Fielding et al., 2008; Waterhouse \& Shi, 2013). 
The focus of this study is on the Lower Permian Grant Group of the Canning Basin (Fig. 1). Field and subsurface sedimentological and paleontological analyses of the group indicate it was deposited within glacial-influenced environments (Figs. 2A, B and C; Redfern, 1990; Redfern and Millward, 1994; Apak and Backhouse, 1998, 1999; Martin et al, 2007; Martin, 2008; Mory et al., 2008; Veevers, 2009). The age of the Grant Group is largely constrained by palynology (the Pseudoreticulatispora confluens and Microbaculispora tentula spore-pollen zones; Apak and Backhouse, 1998, 1999; Mory, 2010), and Asselian to early Sakmarian foraminifera-brachiopod-gastropod assemblages from exploration coreholes and wells on the Barbwire Terrace and outcrop in St. George Ranges (Foster and Waterhouse, 1988; Archbold, 1995, 1999; Taboada et al., 2015). SHRIMP U-Pb age control for equivalent ammonite and palynozones in eastern Australia (Roberts et al., 1995; 1996), corrected following Black et al. (2003), provide a lower absolute age limit of c. $296 \mathrm{Ma}$, indicating the Grant Group was deposited between the late Asselian and early Sakmarian (Fig. 3). However, preliminary TIMS U-Pb dating of eastern Australia successions suggests $P$. confluens could be slightly older with the M. tentula Zone extending into the latest Carboniferous, although Bodorokos et al. (2016) indicate this is based on relatively few sample analyses.

Although the underlying Reeves Formation has been considered to be glacial or preglacial (Redfern, 1990; Redfern and Millward, 1994; Kennard et al., 1994; Apak and Backhouse, 1998, 1999; Mory et al., 2008; Veevers, 2009), recent seismic interpretation suggests it is predominantly a syn-rift, pre-glacial succession (Al-Hinaai \& Redfern, 2015). The age of the Reeves Formation in the Fitzroy Trough spans the late Visean to c. Moscovian based on relatively imprecise palynology (Grandispora maculosa to Diatomozonotriletes birkheadensis spore-pollen zones; Apak and Backhouse, 1998, 1999; Veevers, 2009; J. Backhouse, pers. comm., 2018). On the terraces flanking the Fitzroy Trough, palynomorphs in the Grant Group are now considered to be from the latest Pennsylvanian to Asselian or early Sakmarian $M$. 
tentula and P. confluens spore-pollen zones. In those areas (Lennard Shelf to the north and Barbwire Terrace to the south) the group usually unconformably overlies Devonian and older rocks (Fig. 3). There is a probable depositional hiatus (and/or erosion) spanning at least the middle to late Pennsylvanian between the Reeves Formation and Grant Group in the Fitzroy Trough whereas on the flanking sub-basins that break is often larger.

\section{RATIONALE AND METHODOLOGY}

Detrital zircon provenance analysis on three sandstone core samples from the Grant Group of the Crossland Platform (sample DRO), Barbwire Terrace (sample CAP), and Fitzroy Trough (sample CYC) was undertaken to investigate the location of former glacial centres and associated ice-sheet dynamics, and to identify major sediment transport routes into Canning Basin during the LPIA (Fig. 1). Combined $\mathrm{U}-\mathrm{Pb}$ dating and $\mathrm{Lu}-\mathrm{Hf}$ isotope geochemistry was applied to detrital zircon samples using laser ablation multi-collector inductively coupled plasma mass spectrometry (LA-MC-ICPMS). U-Pb dating of detrital zircons is a well established method for determining provenance and improving paleogeographic reconstructions and tectonostratigraphic models (e.g. Cawood and Nemchin, 2000; Fedo et al., 2003; Veevers et al., 2005). It is particularly effective in regions with a good geochronological database of potential source areas, as is the case for Australia, where the complex evolution of many basement terranes have been resolved using SHRIMP technology (e.g. Camacho and Fanning, 1995; Bruguier et al., 1999; Buick et al., 2001). Increasingly, provenance studies combine Lu-Hf isotope geochemistry with $\mathrm{U}-\mathrm{Pb}$ dating of detrital zircons to reveal further information on the composition of the source area. Lu-Hf isotope geochemistry provides information about the evolution of the crust in which the zircons crystallized, therefore is a useful supplement to the age information gained by $\mathrm{U}-\mathrm{Pb}$ dating, particularly in differentiating sub-populations of zir- 
cons of the same age (e.g., Veevers et al., 2005; Flowerdew et al., 2007). A full explanation of the zircon geochronology methodology employed is provided in Appendix A. Correlation of detrital zircons with potential source areas using $\mathrm{U}-\mathrm{Pb}$ age and $\mathrm{Lu}-\mathrm{Hf}$ isotope data was constrained with field outcrop and subsurface interpretation (from Martin et al., 2007; Mory et al., 2008; Al-Hinaai \& Redfern, 2015), and is summarized below.

\section{FIELD AND SUBSURFACE OBSERVATIONS}

The Grant Group outcrops along the northern, southern and eastern basin margins, and within a series of inversion-related anticlines along the Fitzroy Trough (Fig. 1 and 2H). Sedimentological evidence indicating the glacial origin of the Grant Group includes striated pavements overlain by diamictite (Fig. 2A; Playford, 2002), striated and faceted clasts within various glaciogenic facies, intraformational iceberg striae (O’Brien and Christie-Blick, 1992; Martin, 2008), cold-water marine fauna (e.g. the bivalve Eurydesma; Archbold and Shi, 1995), and ice-rafted debris (e.g. Figs. 2B and 2C). In the subsurface, the group is widely distributed and has been a target for numerous petroleum exploration wells with several modest discoveries made to-date, including the Sundown and Blina oil fields, both within the Lennard Shelf. About 30 fully cored boreholes in the Barbwire Terrace contain a typical suite of glaciogenic facies, including diamictite, varved mudrock with dropstones and rare facetted and striated clasts. These wells together with subsurface imaging provided by numerous seismic surveys provide important constraints on Grant Group stratigraphy and depositional settings across the wider Canning Basin. Field and subsurface observations pertinent to the regional glaciation model are outlined below.

\section{Glacial erosional features}


In the Pilbara and Yilgarn cratons south of the Canning Basin, striated pavements and tunnel valleys (Eyles and de Broekert, 2001; Playford, 2002; Williams, 2007; Mory et al., 2008), clearly indicate major ice sheets developed over cratonic uplands of Western Australia during the LPIA and advanced northwards and eastwards into the Canning Basin. Tillites overlying striated surfaces of the Paleoproterozoic Pinjian Chert Breccia in the Oakover River area of the Pilbara Craton (Williams, 2007) contain P. confluens palynomorphs, confirming an Early Permian age (Backhouse, 1992). In central Australia, east of the Canning Basin, glacial striated pavements near Dover Hills in the Amadeus Basin provide evidence of ice movement to the west (Haines et al., 2011). No striated pavements in basement terranes north of the Canning Basin have been reported to our knowledge, although Playford et al. (2009) described striated pavements on Devonian limestone in the eastern Lennard Shelf.

In the subsurface, the Grant Group rests unconformably on strata variably ranging from Ordovician to Carboniferous in age across the Canning Basin. Basal lithologies overlying the Base Grant Unconformity (BGU) are variably diamictite, conglomerate or coarsegrained sandstone facies that are typical of glacial successions. The BGU is marked in places by $\mathrm{N}$ to NE U-shaped valleys up to $400 \mathrm{~m}$ deep and $10 \mathrm{~km}$ wide that, in southern and central areas of the basin (e.g. Al-Hinaai \& Redfern, 2015). On the Lennard Shelf, valleys directed to the S to SW and infilled by stacked channel successions have been mapped on both $2 \mathrm{D}$ (O’Brien et al., 1998) and 3D seismic (Al-Hinaai, 2013). Multiple intra-formational erosion surfaces are present throughout the basin. These are predominantly but not exclusively developed within lower Grant Group intervals (Al-Hinaai \& Redfern, 2015).

\section{Glacial depositional record}


Seismic calibrated by wells indicate rifting in the northern Fitzroy Trough and along the Lennard Shelf during the Devonian-Carboniferous ('Pillara' extension) and subsequently, and to a greater magnitude, in the southern Fitzroy Trough along the Barbwire Terrace during the latest Carboniferous - earliest Permian ('Point Moody' extension; Kennard et al., 2004). The Carboniferous succession within the Fitzroy Trough thickens southwards, with seismic showing significant expansion of the Reeves Formation towards the southern major basin bounding faults, such as the Fenton Fault (Al-Hinaai \& Redfern, 2015). The majority of these faults terminate at the BGU, indicating the Grant Group was deposited during a phase of post-rift thermal subsidence in the northern Canning Basin, contrary to some sedimentological models, which interpret it as a syn-rift succession (e.g. Eyles \& Eyles, 2000).

Based on sedimentological and stratigraphical evaluations of the Fitzroy Valley outcrops and subsurface cored sections from the Barbwire Terrace and Crossland Platform, the Grant Group in the northern Canning Basin was deposited within glaciated shallow marine and proglacial fluvial-deltaic environments (Redfern \& Williams, 2002; Martin, 2008). Lower facies associations comprise a complex succession of basin marginal facies, deposited from gravity flows (Fig. 2C), turbidity currents (Fig. 2D), and sediment remobilisation and suspension processes. Basin axial facies record deposition in storm-influenced glaciomarine environments with proglacial channel complexes (Fig. 2G). Lower facies evidently were deposited whilst ice-margins were in direct contact with the Fitzroy Trough seaway (as shown by diamictites with striated clasts, ice-rafted debris; Fig. 2B). Upper facies associations record gradual retreat of ice from the northern Canning Basin with 'direct' evidence for glaciation generally diminishing up-sections. Extensive fossiliferous glaciomarine mudstone facies record maximum flooding in the Canning Basin, and were followed by progressive shoreline regression marked by fluvial-dominated delta systems (Figs. 2E, 2F and 2H). Paleocurrents and sedimentary structures from various intervals within the glaciomarine and deltaic successions, 
including intraformational striae and cross-bedding of stacked channel sandstones, record predominantly offshore directed (towards NW) axial sediment paleo-flow in the Fitzroy Trough (Fig. 4).

\section{Implications for the regional glaciation model}

Seismic and well interpretation provides important constraints on the Grant Group depositional and regional LPIA glaciation models. They indicate the Grant Group is dominantly a post-rift succession with deposition strongly influenced by pre-existing rift topography and glacial processes. Seismic mapping of glacially-eroded valleys and their sedimentary fill provide important constraints on paleo-ice flow directions and can facilitate correlation of detrital zircons with their source areas. There is good evidence for valley systems emanating from the basement areas flanking all margins of the Canning Basin, implying there is potential for a complex provenance model (Al-Hinaai \& Redfern, 2015). Outcrop measurements further constrain provenance of the Grant Group, notably: 1) basin marginal striated pavements indicate ice advanced basinwards from the south and east, and 2) paleocurrent measurements from proglacial successions in the Fitzroy Trough indicate offshore-directed axial sediment transport from source areas in the east, possibly influenced by lateral sediment input from the south and north.

\section{DETRITAL ZIRCON SAMPLE ANALYSES}

Detrital zircons analysed for this study were from cored Grant Group intervals in the northern Canning Basin (Fig. 1). A total of $181 \mathrm{U}-\mathrm{Pb}$ ages were determined from three samples, with Hf isotope geochemistry performed on a sub-population of 117 zircons. Samples for zircon 
extraction were selected from a larger set following detrital heavy mineral petrography.

Heavy minerals in all samples are dominated by garnet, tourmaline and zircon, and a wide variety of minor constituent minerals including anatase, apatite, and rutile (Table 1).

\section{Sample DRO}

Sample DRO is from a thick turbidite/density flow sandstone succession in petroleum well Drosera-1 (192.9 m) on the northern margin of the Crossland Platform (Fig. 1), interpreted as glacial gravity flow deposits released directly from an ice margin (Martin, 2008; Fig. 6). A total of $61 \mathrm{U}-\mathrm{Pb}$ zircon age determinations were obtained from this sample, ranging from 2828 to $306 \mathrm{Ma}$ (Table 2; Fig. 8). Lu-Hf isotope geochemical analysis was applied to a subpopulation of 41 zircons, yielding a wide variety of ${ }^{176} \mathrm{Hf} /{ }^{177} \mathrm{Hf}$ ratios corresponding with $\varepsilon \mathrm{Hf}$ values ranging from $-22.1-+14.4$, and $\mathrm{T}_{\mathrm{DM}}$ model ages of $3.04-0.72 \mathrm{Ga}$ (Table 5; Fig. 9). Significant ${ }^{207} \mathrm{~Pb}^{*} /{ }^{206} \mathrm{~Pb} *$ age populations include: 1) Paleoproterozoic to Early Mesoproterozoic (1796-1449 Ma), with $\varepsilon H f$ values of $-3.8-+8.3$, and $\mathrm{T}_{\mathrm{DM}}$ model ages of $2.22-1.72 \mathrm{Ga}$, and 2) Mesoproterozoic (1289-1164 Ma), with $\varepsilon H f$ values of $-5.6-+7.6$, and $\mathrm{T}_{\mathrm{DM}}$ model ages of $1.87-1.43 \mathrm{Ga}$. Late Neoproterozoic to Cambrian ${ }^{206} \mathrm{~Pb}^{*} /{ }^{238} \mathrm{U}$ ages of $602-508 \mathrm{Ma}$ also form a relatively significant population with $\varepsilon H f$ values of $-22.2-+0.9$, and $\mathrm{T}_{\mathrm{DM}}$ model ages of 1.93-1.11 Ga. Remaining zircon ages include a single Archean age, several Paleoproterozoic and Neoproterozoic ages, and four Devonian to Pennsylvanian ages. The youngest zircon from sample DRO (dro66c) has a ${ }^{206} \mathrm{~Pb}^{*} / 238 \mathrm{U}$ age of $306 \pm 8 \mathrm{Ma}(2 \sigma, 96 \%$ concordant), $\varepsilon \mathrm{Hf}$ of -0.8 , and $\mathrm{T}_{\mathrm{DM}}$ model age of $0.94 \mathrm{Ga}$ (Tables 2 and 5).

\section{Sample CAP}


Sample CAP is from a massive sandstone associated with matrix-supported diamictites in petroleum well Capparis-1 (106.9 m) on the Barbwire Terrace (Fig. 1), interpreted as glacial density flow deposits released directly from an ice margin (Martin, 2008; Fig. 6). A total of $60 \mathrm{U}-\mathrm{Pb}$ age determinations were obtained from CAP zircons, ranging from 2908 to $298 \mathrm{Ma}$ (Table 2; Fig. 8). Lu-Hf isotope geochemical analysis applied to a sub-population of 39 zircons, yielded a wide variety of ${ }^{176} \mathrm{Hf} /{ }^{177} \mathrm{Hf}$ ratios corresponding with $\varepsilon \mathrm{Hf}$ values ranging from $-21.3-+10.4$, and $\mathrm{T}_{\mathrm{DM}}$ model ages from 3.25-1.05 Ga (Table 5; Fig. 9). Significant ${ }^{207} \mathrm{~Pb}^{*} /{ }^{206} \mathrm{~Pb}^{*}$ populations include, 1) Paleoproterozoic to Early Mesoproterozoic ages of 1802-1492 Ma with $\varepsilon H f$ values of $-4.3-+4.0$, and $\mathrm{T}_{\mathrm{DM}}$ model ages of $2.25-1.93 \mathrm{Ga}$, and 2) Mesoproterozoic ages of 1329-1086 Ma with $\varepsilon H f$ values of $-10.2-+5.7$, and $\mathrm{T}_{\mathrm{DM}}$ model ages of 2.03-1.38 Ga. Late Neoproterozoic to Devonian ${ }^{206} \mathrm{~Pb} * / 238 \mathrm{U}$ ages of $604-408 \mathrm{Ma}$, with $\varepsilon \mathrm{Hf}$ values of $-21.3--1.1$ and $\mathrm{T}_{\mathrm{DM}}$ model ages of $1.93-1.16 \mathrm{Ga}$, also form a relatively significant population (Tables 2 and 5). Remaining zircon ages include a single Archean age, several Paleoproterozoic and Neoproterozoic ages, and several Mississippian to Early Permian ages. The youngest zircons from sample CAP (cap44b and cap103a) have ${ }^{206} \mathrm{~Pb} * / 238 \mathrm{U}$ ages of $298 \pm 6 \mathrm{Ma}(82 \%$ concordant) and $304 \pm 8 \mathrm{Ma}(94 \%$ concordant), with $\varepsilon$ Hf values of -11.4 and 11.5 , respectively and $\mathrm{T}_{\mathrm{DM}}$ model ages of $1.35 \mathrm{Ga}$ for both suggesting a common origin (Tables 3 and 4). Additional ablations for samples cap44b and cap103a yielded ${ }^{206} \mathrm{~Pb} * p^{238} \mathrm{U}$ ages of $305 \pm 5$ and $306 \pm 5 \mathrm{Ma}$, respectively. The weighted average $\mathrm{U}-\mathrm{Pb}$ age for these four CAP ages is $303.8 \pm 2.8 \mathrm{Ma}$ (Fig. 10).

\section{Sample CYC}

Sample CYC is from a cross-bedded sandstone succession in petroleum well Cycas-1 (999.6 m) in the Fitzroy Trough (Fig. 1), interpreted as a proglacial fluvial channel sandstone analo- 
gous to cross-bedded channel sandstones identified in the Grant Group outcrops at Grant Range (Martin, 2008; Figs. 2G \& 6). A total of $60 \mathrm{U}-\mathrm{Pb}$ age determinations were obtained from CYC zircons, ranging from 3359 to 297 Ma (Table 2; Fig. 8). Lu-Hf isotope geochemical analysis was applied to a sub-population of 37 zircons, yielding a wide variety of ${ }^{176} \mathrm{Hf} /{ }^{177} \mathrm{Hf}$ ratios corresponding with $\varepsilon \mathrm{Hf}$ values ranging from $-27.7-+11.1$, and $\mathrm{T}_{\mathrm{DM}}$ model ages from 3.05-0.75 Ga (Table 5; Fig. 9). Significant ${ }^{207} \mathrm{~Pb}^{*} /{ }^{206} \mathrm{~Pb}^{*}$ populations include, 1) Paleoproterozoic to Early Mesoproterozoic ages of 1866-1472 Ma with عHf values of -3.6 +7.6 and $\mathrm{T}_{\mathrm{DM}}$ model ages of 2.38-1.77 Ga, and 2) Mesoproterozoic ages of 1374-1037 Ma with $\varepsilon \mathrm{Hf}$ values of $-6.8-+5.1$ and $\mathrm{T}_{\mathrm{DM}}$ model ages of $2.55-1.44 \mathrm{Ga}$. Remaining ages include several Archean to Early Paleoproterozoic, Neoproterozoic, and Cambrian to Early Permian ages. The youngest zircon from sample CYC (cyc78b) has a ${ }^{206} \mathrm{~Pb}^{*} /{ }^{238} \mathrm{U}$ age of $297 \pm 7 \mathrm{Ma}$ $(2 \sigma, 91 \%$ concordant; Table 2$)$.

\section{Detrital zircon age distribution summary}

The $\mathrm{U}-\mathrm{Pb}$ age probability distribution and $\mathrm{U}-\mathrm{Pb}$ age versus $\varepsilon \mathrm{Hf}$ plots (Figs. 8 and 9) show two major populations: 1) zircons with Paleo- to Early Mesoproterozoic ${ }^{207} \mathrm{~Pb}^{* / 206} \mathrm{~Pb}^{*}$ ages (1850-1450 Ma), $\varepsilon H f$ values from -4 to +8 , and $\mathrm{T}_{\mathrm{DM}}$ model ages of $2.4-1.7 \mathrm{Ga}$, and 2 ) zircons with Mesoproterozoic ${ }^{207} \mathrm{~Pb}^{*} /{ }^{206} \mathrm{~Pb} *$ ages (1350-1050 Ma), \&Hf values from -11 to +6 , and $\mathrm{T}_{\mathrm{DM}}$ model ages of 2.6-1.4 Ga. Zircon ${ }^{206} \mathrm{~Pb} * / 238 \mathrm{U}$ ages $<1000 \mathrm{Ma}$ are also relatively abundant in all samples (total $\mathrm{N}=58$; Table 2; Figs. 7 and 8). Hf isotope data for these grains is defined by an array of highly negative to low positive $\mathrm{eHf}$ values (Table 5). Zircons with Archean to Paleoproterozoic ${ }^{207} \mathrm{~Pb}^{*}{ }^{206} \mathrm{~Pb}^{*}$ ages of c. $3350-1900$ are very scarce in all samples. 


\title{
DETRITAL ZIRCON CORRELATION WITH POTENTIAL SOURCE AREAS
}

\section{Archean detritus}

\author{
DESCRIPTION
}

Archean zircons are generally rounded and their textures reveal a relatively complex history with igneous growth zoning, convoluted by late-to-post magmatic recrystallization (Fig. 5A). They all have thin, variably homogeneous and zoned rim phases presumably formed by a later metamorphic or magmatic event, and some have xenocrystic cores. Rims and cores are too small to ablate without overlapping with other phases.

\section{ARCHEAN PB-PB CRYSTALLISATION AGES}

Only five detrital zircons from this dataset have Archean crystallization ages, with ${ }^{207} \mathrm{~Pb}^{*} /{ }^{206} \mathrm{~Pb} *$ ages of $3359-2858 \mathrm{Ma}$ (Table 2; Figs. 7 and 8). These are broadly similar to ages from the Pilbara and Yilgarn cratons that record several tectonic episodes spanning $\sim 3.5$ - 2.8 Ga with inherited zircons up to $3.72 \mathrm{Ga}$ (e.g. Hickman, 2004; Van Kronendonk et al., 2007). Archean detrital and inherited zircons are also reported from meta-sedimentary and igneous units of the Capricorn Orogen, Hamersley Basin and Rudall Complex, which also lie south of the Canning Basin (Fig. 1; Neumann and Fraser, 2007). To the north of the Canning Basin, primary Archean basement exposures are limited, although geophysical surveys indicate the North Australian Craton is widespread in the subsurface of the region. Archean outcrops are present within the Neoarchean Pine Creek Orogen, although their age (2.67-2.5 Ga) is younger than the Canning Basin detrital zircons (Worden et al., 2008; Hollis et al., 2009). 
In addition, detrital zircons with ages of $\leq 2.55 \mathrm{Ga}$ are reported from the Hooper Complex in the Kimberley region (Tyler et al., 1999), and several detrital ages of $3.12-3.68$ Ga from the Paleoproterozoic Crater Formation in the Pine Creek Orogen (Hollis et al., 2010). An imprecise $\mathrm{Re}-\mathrm{Os}$ isochron age of $\sim 3.4 \mathrm{Ga}$ has also been recorded from xenoliths and chromites of the Kimberley region (Graham et al., 1999). Neoarchean crystallization ages equivalent to those from the Pine Creek Orogen are also reported from areas east of the Canning Basin in the Tanami Billabong Complex (Joly et al., 2013 and references therein).

\section{ARCHEAN $T_{\text {DM }}$ MODEL AGES AND $\varepsilon H F$ VALUES}

Hf isotope data for several detrital zircon samples analysed have $\varepsilon H f$ values from -3.4 to +5.5 and $\mathrm{T}_{\mathrm{DM}}$ model ages of 3.25-3.04 Ga (Table 5). Sample cycla has similar ${ }^{207} \mathrm{~Pb}^{*} /{ }^{206} \mathrm{~Pb}^{*}$ and $\mathrm{T}_{\mathrm{DM}}$ model ages and positive $\varepsilon \mathrm{Hf}$ values suggesting it formed from primitive melts closely approximating the crystallization age (Fig. 9). Low negative $\varepsilon H f$ values indicate remelting and/or mixing of older Archean crust during crystallization (Kinny and Maas, 2003). Potential source areas with similar $\mathrm{Nd}$ isotope characteristics, albeit with only positive $\varepsilon \mathrm{Nd}$ values, are reported from various units of the Western and Eastern Pilbara terranes (Van Kronendonk et al., 2007). Hf isotope data from the Yilgarn Craton also has similar $\varepsilon H f$ values and $\mathrm{T}_{\mathrm{DM}}$ model ages as the Canning Basin detrital zircons, including low negative $\varepsilon H f$ values (Griffin et al., 2004; Ivanic et al., 2013). In the Pine Creek Orogen, magmatic zircons with 2.67-2.5 Ga crystallization ages from the granitic Nimbuwah Domain have $\varepsilon H f$ values from -8.9 to 3.4 and $\mathrm{T}_{\mathrm{DM}}$ model ages of $3.65-3 \mathrm{Ga}$. By comparison, detrital zircons with 3.68-3.12 Ga U-Pb crystallization ages have $\varepsilon H f$ values between -5.7 and -0.3 and $\mathrm{T}_{\mathrm{DM}}$ model ages of $\sim 4-3 \mathrm{Ga}$ (Hollis et al., 2010). 


\section{IMPLICATIONS FOR SOURCE AREA CORRELATION}

Archean detrital zircons constitute only a minor component of the total dataset hence it is apparent that Archean cratons were not significant sediment source areas for the northern Canning Basin. This is despite striated pavements and tunnel valleys clearly indicating the Early Permian ice sheet advanced northwards from the Pilbara region into the Canning Basin (e.g. Fig. 2A). It is not possible with available isotopic data to distinguish whether Grant detrital zircons came from Archean basement to the south, north or east of the Canning Basin, and/or from recycling of detrital grains.

\section{Paleoproterozoic to Lower Mesoproterozoic detritus}

\section{DESCRIPTION}

Zircons with Paleo- to Early Mesoproterozoic ${ }^{207} \mathrm{~Pb}^{*} /{ }^{206} \mathrm{~Pb}^{*}$ ages have a diverse range of textures of both igneous and metamorphic origin, with many recording a complex crystallization history. Igneous zircons vary considerably with homogeneous centres passing into zoned margins, fine oscillatory zoning sometimes with truncation surfaces formed during resorption, acicular grains with a relatively muted CL response (Fig. 5B), and convoluted zoning related with post-to-late magmatic recrystallization (Corfu et al., 2003). Xenocrysts in many grains commonly are surrounded by new magmatic zircon growth (Fig. 5C). Homogeneous rim overgrowths are also present. Grain morphology is relatively varied with preservation of terminations on some whereas others appear more rounded. It is difficult to deduce if older rounded grains came from primary sources or were reworked, as rounded zircons can also de- 
velop from in-situ growth of metamorphic rims around euhedral magmatic grains (Corfu et al., 2003).

\section{PALEOPROTEROZOIC TO LOWER MESOPROTEROZOIC PB-PB CRYSTALLISA- TION AGES}

Paleo- to Early Mesoproterozoic ${ }^{207} \mathrm{~Pb}^{*} /{ }^{206} \mathrm{~Pb} *$ ages of $\sim 1800-1450$ Ma constitute a major component of the total dataset within all three samples analysed (Table 2). Although relative abundances of such ages varies slightly between samples, all are characterized by age spikes of 1765-1715, 1660-1600 and 1555-1550 Ma (Figs. 8 and 9). Paleoproterozoic ${ }^{207} \mathrm{~Pb}^{*} /{ }^{206} \mathrm{~Pb} *$ ages $>1900 \mathrm{Ma}$ are scarce in all three samples, with only several scattered ages between $\sim 2385 \mathrm{Ma}$ and $\sim 1919 \mathrm{Ma}$ recorded in the three samples. Sample CYC has three ${ }^{207} \mathrm{~Pb}^{*} /{ }^{206} \mathrm{~Pb}^{*}$ ages between $\sim 1890 \mathrm{Ma}$ and $\sim 1865 \mathrm{Ma}$ that are not present in samples CAP and DRO (Table 2).

Paleoproterozoic zircon-forming events of c. 1.8-1.7 Ga are widely reported from basement terranes adjacent to the Canning Basin. To the north, these include a $\sim 1.79 \mathrm{Ga}$ intrusive event from the Halls Creek Orogen, Tanami granite intrusion at $\sim 1.82-1.79 \mathrm{Ga}$ (Sener et al., 2005), the $\sim 1.71 \mathrm{Ga}$ Devils Suite granites and dykes from the Tennant region and the $\sim 1.8-1.75$ Ga Shoobridge Event in the Pine Creek Orogen. East of the basin, these include the 1.81-1.80 Ga Stafford and 1.74-1.69 Ga Strangeways events from the Arunta Inlier (Giles et al. 2004; Maidment et al., 2005; Hoatson et al., 2005) and, to the south, the 1.83-1.79 Ga Capricorn Orogeny (Cawood and Tyler, 2004) and the $1.80-1.76$ Ga Yapungku Orogeny from the Rudall Complex (Bagas, 2004). Grant Group detrital zircons with 1.8-1.7 $\mathrm{Ga} \mathrm{Pb}-\mathrm{Pb}$ ages could be sourced from any of these basement terranes, which make direct correlation with $\mathrm{Pb}-\mathrm{Pb}$ ages alone difficult. 
Ages of $1.69-1.52 \mathrm{Ga}$ that correspond with age spikes at c. $1550 \mathrm{Ma}$ in all three samples, and age spikes at c. 1660 in samples CAP and CYC (Table 2), are widely reported from basement terranes to the east and south of the Canning Basin. To the east, they are equivalent with the c. 1.69-1.63 Ga Liepig Event, the c. 1.59-1.57 Ga Chewings Event and several other igneous events of the Arunta Inlier (Collins et al., 1995; Rubatto et al., 2001; Hoatson et al., 2005), volcanics in the Limbunyah Group of the Tanami Region dated at c. $1.64 \mathrm{Ga}$, and c. 1.60-1.54 Ga protoliths of the Musgrave Block (White et al., 1999; Neumann and Fraser, 2007; Wade et al., 2005, 2006). To the south of the Canning Basin, these ages are equivalent with the c. 1.68-1.62 Ga Mangaroon Orogeny of the Capricorn Orogen, and c. 1.59-1.55 Ga Tabletop Intrusives of the Rudall Complex (Neumann and Fraser, 2007). Ages of 1690-1520 Ma ages are not widely recorded from basement terranes to the north of the Canning Basin; the exceptions are recorded from several igneous intrusive bodies in the Pine Creek Orogen dated at $\sim 1.72-1.60 \mathrm{Ga}$ (Neumann and Fraser, 2007). Early Mesoproterozoic magmatic events are also widely reported from terranes of central and eastern Australia, including the Gawler Craton, Curnamona Province, and Georgetown and Mount Isa Inliers (Betts et al., 2002, 2006; Giles et al., 2004).

In basement terranes surrounding the Canning Basin, zircons $>1800 \mathrm{Ma}$ are less widespread than those of $<\mathbf{1 8 0 0}$ Ma. A cluster of three ages between $\sim 1890 \mathrm{Ma}$ and 1865 Ma in sample CYC possibly corresponds to the Hooper Orogeny, recorded in the Halls Creek and King Leopold orogens, and the Nimbuwah Event, in the Pine Creek Orogen (Bodorokos et al., 1999; Griffin et al., 2000). Basement terranes in Western Australia with Paleoproterozoic zircon-forming events $>1900$ Ma include the Capricorn Orogen, which records a wide range of igneous and metamorphic events at 2.55-1.62 Ga (Cawood and Tyler, 2004; Griffin et al., 2004), and, to lesser extents, the Halls Creek Orogen, with igneous intrusions dated 
at $\sim 1.91 \mathrm{Ga}$ (Bodorokos et al., 1999), and the Pine Creek Orogen, with igneous intrusions of $\sim 2.47$ and $2.02 \mathrm{Ga}$ (Hollis et al., 2010).

\section{PALEOPROTEROZOIC TO LOWER MESOPROTEROZOIC $\mathrm{T}_{\mathrm{DM}}$ MODEL AGES AND $\varepsilon H F$ VALUES}

Paleoproterozoic detrital zircons with $1.79-1.61 \mathrm{Ga} \mathrm{Pb}-\mathrm{Pb}$ ages have low negative and positive $\varepsilon H f$ values and Paleoproterozoic $\mathrm{Hf}_{\mathrm{DM}}$ model ages $>1.9 \mathrm{Ga}$ (Fig. 9) indicating they were derived from partially juvenile melts which assimilated variable amounts of evolved, continental crust. Many of these are equivalent to available $\mathrm{Hf}$ and Nd isotope data from subduction, back-arc and intracontinental intrusions of the Arunta Inlier (Zhao and McCulloch, 1993, 1995; Sun et al., 1995; Hoatson et al., 2005; Hollis et al., 2013), with some of the older grains ( 1800-1760 Ma Pb-Pb) slightly overlapping with $\mathrm{Lu}-\mathrm{Hf}$ data from the Capricorn Orogen, Rudall Complex and Hall's Creek Orogen (Fig. 11; Griffin et al., 2004; Kirkland et al., 2013). Other Paleoproterozoic detrital zircons have crystallization ages $>1800 \mathrm{Ma}$ but constitute only isolated samples hence have limited correlative potential. These include a cluster of several grains with $1830-1810 \mathrm{Ma} \mathrm{Pb}-\mathrm{Pb}$ ages with $\varepsilon \mathrm{Hf}$ values from -3.5 to +1.0 and $\sim 2.21-2.17 \mathrm{Ga} \mathrm{Hf} \mathrm{T}_{\mathrm{DM}}$ model ages that overlap with $\mathrm{Lu}-\mathrm{Hf}$ data from potential source regions to the east (Arunta; Hollis et al., 2013), south (Rudall; Kirkland et al., 2013) and north (Kimberley and Hall's Creek Orogen; Griffin et al., 2000; Sheppard et al., 2001; Downes et al., 2007) of the Canning Basin. A couple of older Paleoproterozoic grains have moderately negative $\varepsilon H f$ values and Neoarchean $\mathrm{Hf}_{\mathrm{DM}}$ model ages (Fig. 9).

Early Mesoproterozoic detrital zircons with $\sim 1600-1500 \mathrm{Ma} \mathrm{Pb}-\mathrm{Pb}$ ages have low positive and negative $\varepsilon \mathrm{Hf}$ values and Paleoproterozoic model ages that are correlative with several potential source terranes flanking the basin, including $\mathrm{Hf}$ and $\mathrm{Nd}$ isotope data from the 
Musgrave Block (Wade et al., 2006; Kirkland et al., 2012), Rudall Complex (Kirkland et al., 2013) and Yilgarn (Griffin et al., 2004; Fig. 11). Farther afield in Queensland, Hf isotope data from Mt Isa Inlier for zircons with U-Pb ages of 1590-1540 Ma yield a variety of positive and negative $\varepsilon H f$ values, with a major peak of +3 (Griffin et al., 2006).

\section{IMPLICATIONS FOR SOURCE AREA CORRELATION}

Overlapping $\mathrm{Pb}-\mathrm{Pb}$ and $\mathrm{Lu}-\mathrm{Hf}$ values between Grant Group detrital zircons and data from various basement terranes flanking the Canning Basin suggest candidate source terranes to the east, south and north of the basin. This can be further constrained using three key observations: 1) the overall paucity of $\mathrm{Pb}-\mathrm{Pb}$ ages $>1900$ Ma suggests terranes to the south and to the north of the Canning Basin were not principal source areas, 2) Grant Group detrital zircons with $\sim 1700-1600 \mathrm{Ma} \mathrm{Pb}-\mathrm{Pb}$ ages have Hf isotopic data very similar to $\mathrm{Hf}$ and $\mathrm{Nd}$ isotopic data reported from the Arunta Inlier (Zhao and McCulloch, 1993, 1995; Sun et al., 1995; Hoatson et al., 2005; Hollis et al., 2013) and 3), Pb-Pb ages of 1890-1865 Ma in Fitzroy Trough sample CYC may be correlated with terranes to the north of the Canning Basin, although reworking of detrital zircons of similar ages reported from other areas cannot be ruled out (Claoué-Long et al., 2008).

\section{Mesoproterozoic detritus}

\section{DESCRIPTION}

Zircons with c. $1350-1050$ Ma Mesoproterozoic ${ }^{207} \mathrm{~Pb}^{*} /{ }^{206} \mathrm{~Pb} *$ ages have both igneous and metamorphic textures, with some recording a complex crystallization history. Textures ob- 
served include growth zoning, sometimes as a relatively homogeneous core conformably succeeded by oscillatory zoned margins (Fig. 5D), occasionally with evidence for resorption and late-to-post magmatic (possibly metamorphic) recrystallization. Xenocrystic cores are present in several grains, encased by new magmatic zircon with distinct growth zoning (Fig. 5E). In such cases, the younger phase was ablated when possible. Several grains have rims that may represent a younger metamorphic or magmatic event, although they are too thin to analyse. Rims are often homogeneous, although zoned igneous rims were also observed (Fig. 5F).

\section{MESOPROTEROZOIC PB-PB CRYSTALLISATION AGES}

Detrital zircons with Mesoproterozoic $\mathrm{Pb}-\mathrm{Pb}$ ages of 1350-1050 Ma are abundant in all Canning Basin samples and correspond with an age spike at c. $1150 \mathrm{Ma}$ in all three samples, and an age spike at c. $1090 \mathrm{Ma}$ in samples CAP and CYC (Table 2; Fig. 9).

1350-1050 Ma ages are equivalent with major Grenvillian events in the Musgrave Block, including widespread granitoid intrusion dated at c. 1.18-1.15 Ga during the Musgrave Orogeny, a younger phase of felsic magmatism, mafic dyke intrusion and metamorphism of c. 1.09-1.07 Ga and the magmatic Giles Event at 1.08-1.04 Ga (Camacho and Fanning, 1995; White et al., 1999; Schmidt et al., 2006). Other Grenvillian-aged events include dyke intrusion in the Arunta Inlier (Zhao and McCulloch, 1993) and, to the south of the Canning Basin, 1.29 Ga pegmatites and a 1.22 Ga microgneiss in the Connaughton Terrane of the Rudall Complex (Neumann and Fraser, 2007). To the north, 1.32 Ga mafic magmatism is reported from the Arnhem Shelf (Neumann and Fraser, 2007).

MESOPROTEROZOIC T $T_{\text {DM }}$ MODEL AGES AND $\varepsilon H F$ VALUES 
$\mathrm{Lu}-\mathrm{Hf}$ isotope data indicates Grant Group detrital zircons with Mesoproterozoic crystallization ages broadly cluster into two groups: an older Early Mesoproterozoic group described above, and a younger group with $1350-1050 \mathrm{Ma} \mathrm{Pb}-\mathrm{Pb}$ ages, predominantly low positive and negative $\varepsilon H f$ values and Mesoproterozoic model ages (Fig. 9). This latter group strongly correlates with $\mathrm{Hf}$ and $\mathrm{Nd}$ isotope data from various units with equivalent $\mathrm{Pb}-\mathrm{Pb}$ ages in the Musgrave Block, with some of the older grains having mild overlap with Hf data from the Yilgarn (Fig. 11; Zhao et al., 1992; Zhao and McCulloch, 1993; Nelson et al., 1995; Griffin et al., 2004; Wade et al., 2005, 2006; Kirkland et al., 2012).

\section{IMPLICATIONS FOR SOURCE AREA CORRELATION}

$\mathrm{Pb}-\mathrm{Pb}$ and $\mathrm{Lu}-\mathrm{Hf}$ isotopic data suggests Early to Middle Mesoproterozoic detrital zircons were sourced predominantly from the Musgrave Block to the SE of the Canning Basin. A couple of older zircons show overlap with Hf data from more evolved source terranes in the Yilgarn.

\section{Neoproterozoic to Cambrian detritus}

\section{DESCRIPTION}

Zircons with c. $600-500$ Ma Neoproterozoic and Cambrian ${ }^{206} \mathrm{~Pb}^{*} / 238 \mathrm{U}$ ages have zoned textures indicative of an igneous origin whereas others appear homogeneous suggesting a possible metamorphic origin. Zoning varies in both CL intensity and width, with both thicker bands and fine oscillatory zoning sometimes present within the same grain (Fig. 5C). Trunca- 
tions within zoned grains are also relatively common, indicating resorption during recrystallization (Corfu et al., 2003). Thin metamorphic rims are present on several grains.

\section{NEOPROTEROZOIC TO CAMBRIAN PB-PB CRYSTALLISATION AGES}

Detrital zircons with Neoproterozoic and Cambrian ${ }^{206} \mathrm{~Pb}^{*} /{ }^{238} \mathrm{U}$ ages are a significant population in all samples (Table 2; Figs. 7 and 8). Many of the ages are $>10 \%$ discordant, as is typical for relatively young grains containing limited amounts of radiogenic $\mathrm{Pb}$. Samples DRO and CAP are characterized by two broad populations with $\mathrm{U}-\mathrm{Pb}$ ages between c. $965-745 \mathrm{Ma}$ and c. 600-510 Ma that are less abundant in sample CYC (Table 2).

Potential source areas for Neoproterozoic detrital zircons $>745 \mathrm{Ma}$ lie to the east and south of the Canning Basin. These include the c. 825 Ma Gairdner and Amata dolerite dykes intruded throughout the Musgrave Block and Gawler Craton during inception of the Centralian Superbasin (Aitken and Betts, 2009; de Vries et al., 2008; Evins et al., 2010), the c. 1000 Ma Kullal Dolerite (Aitken and Betts, 2009; Evins et al., 2010) and a 980 Ma spike in the population of detrital zircons from an Irindina Gneiss metapelite in the Arunta (Buick et al., 2005). In the Capricorn Orogen, the intracratonic 1070-750 Ma Edmundian Orogeny deformed the Edmund and Collier Basins with pre- and post-deformation mafic intrusions of this age constraining the age (Cawood and Tyler, 2004). Ar-Ar mica ages of 960-820 Ma from several terranes of the Capricorn Orogen indicate regional early greenschist metamorphic conditions (Occhipinti and Reddy, 2009), but it is uncertain if this was a primary zirconforming event. The Mundine Well dyke swarm is dated at c. $755 \mathrm{Ma}$ along the NW margin of the Yilgarn Craton, and the west margin of the Pilbara Craton (reference in de Vries et al., 2008). 
Potential source areas for Neoproterozoic-Cambrian detrital zircons $<600$ Ma near the Canning Basin include the Paterson and Peterman Orogens to the south and east, and the King Leopold Orogen to the north, all of which record crustal shortening in the Late Neoproterozoic and Early Cambrian (c. 600-530 Ma; Maboko et al., 1992; Scrimgeour et al., 1999; Betts et al., 2002; Bagas, 2004; Veevers, 2004; Wade et al., 2005; de Vries et al., 2008; Evins et al., 2010). Other igneous events reported from Western Australia include Cambrian volcanic rocks of the c. 520-500 Ma Kalkarinji Large Igneous Province (Buick et al., 2005), the Boyagin dyke swarm along the western Yilgarn Craton (578-548 Ma), granites in the Paterson Orogen (631-622 Ma), granitoid and dyke intrusions at 540-520 Ma within the Leeuwin Complex (Wilde, 1999; Collins, 2003; Fitzsimons, 2003), and several doleritic intrustions (513-500 Ma; Veevers, 2004). Elsewhere in Australia, 600-500 Ma U-Pb ages are widely distributed in central (Hart's Range, Arunta Inlier; Veevers, 2004), and southern and eastern areas (Delamarian Orogeny; Glen, 2005) during an extensive late Neoproterozic to Cambrian orogenic phase in East Gondwana, with equivalent terranes in Antarctica (Veevers, 2004). Furthermore, detrital zircon studies of Permian and modern sediments confirm their abundance in Western Australia (Sircombe and Freeman, 1999; Cawood and Nemchin, 2000; Veevers et al., 2005).

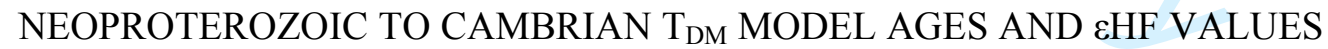

$\mathrm{Lu}-\mathrm{Hf}$ isotope data indicates Neoproterozoic to Cambrian detrital zircons have predominantly low positive and negative $\varepsilon H f$ values with Mesoproterozoic model ages (Fig. 9). Several grains with more complex textures have highly negative $\varepsilon$ Hf values with model ages $>2.0$ Ga. Overall when compared with the relatively limited published $\mathrm{Lu}-\mathrm{Hf}$ dataset from potential source terranes, the Grant Group detrital zircons show overlap with a range of samples 
from the Musgrave, Yilgarn and Officer Basin (Fig. 11; Zhao \& McCulloch, 1993; Griffin et al., 2004; Wade et al., 2005; Kirkland et al., 2012). However, given the paucity of Hf-Nd data from other potential basement terranes, it is difficult to make confident interpretation of source area correlation.

\title{
IMPLICATIONS FOR SOURCE AREA CORRELATION
}

\begin{abstract}
Although Neoproterozoic-Cambrian $\mathrm{U}-\mathrm{Pb}$ ages form a relatively significant population of the total Grant Group detrital zircon dataset, scattered ages imply they were not sourced from a single principal source area. Given their ubiquity in basement terranes in Western Australia and beyond, together with the limited availability of equivalent $\mathrm{Hf}-\mathrm{Nd}$ data, no significant conclusions can be made with respect to source area correlation. The only general observation that can be made is that Grant Grout detrital zircons of this age are more abundant in the Crossland Platform and Barbwire Terrace samples DRO and CAP relative to the Fitzroy Trough sample CYC (Fig. 9).
\end{abstract}

\section{Ordovician to Lower Permian detritus}

\section{DESCRIPTION}

Younger Phanerozoic zircons ranging from Ordovician to Early Permian are exclusively of igneous origin, with predominantly euhedral, prismatic forms, occasionally sub-rounded, and growth zoning which sometimes grade from thicker bands in the centre to fine oscillatory zoning at the margins (Fig. 5B). 


\section{ORDOVICIAN TO LOWER PERMIAN U-PB CRYSTALLISATION AGES}

Detrital zircons with Ordovician to earliest Permian ${ }^{206} \mathrm{~Pb} * / 238 \mathrm{U}$ ages between c. 490 Ma and $297 \mathrm{Ma}$ are present in all three samples, particularly samples CYC and CAP (Table 2). Dates from the youngest grains measured are within $2 \sigma$ error of the biostratigraphic age of the host sediments, implying they approximate 'first-cycle' detritus. Zircon-forming events of this age are widely reported from central Australia where the Arunta Inlier underwent granulite facies metamorphism during the Early Ordovician prior to being exhumed during the Devonian-Carboniferous Alice Springs Orogeny. The Harts Range Metamorphic Complex experienced peak metamorphism at c. $470 \mathrm{Ma}$ (the Larapinta Event of Hand et al. 1999) in the Irindina Gneiss and Harts Range Meta-Igneous Complex (Hand et al. 1999; Mawby et al. 1999; Buick et al. 2001, 2008). Overgrowths from several units have yielded U-Pb ages of c. 452 and $484 \mathrm{Ma}$ (Buick et al., 2005). This was followed by intrusion of basaltic dykes during extension that terminated with onset of the Alice Springs Orogeny at c. 450 Ma (Buick et al., 2005). Inherited zircons with c. $387 \mathrm{Ma} \mathrm{U}-\mathrm{Pb}$ ages are dated from granite intrusives in the Harts Range (Buick et al., 2005). Younger (c. 330 Ma) zircon overgrowths are interpreted as the maximum age of amphibolite-grade metamorphism in Hart's Range (Hand et al., 1999). However, Canning Basin detrital zircons with these ages are relatively euhedral and of magmatic rather than metamorphic origin (e.g. Fig. 5A), suggesting another source. SHRIMP $\mathrm{U}-\mathrm{Pb}$ monazite and zircon ages of c. 450-300 Ma from numerous pegmatites that cross-cut the Harts Range Metamorphic Complex and Entia Gneiss Complex record episodic emplacement throughout the duration of the Alice Springs Orogeny in central Australia (Buick et al., 2008). Similarly aged zircon-forming events have not, to our knowledge, been reported elsewhere in the immediate vicinity of the Canning Basin or Western Australia. 
Potential source areas elsewhere in Australia include the Big Lake Granites of the Cooper Basin, dated at c. 330-300 Ma (Ito, 2010), and terranes of the Delamerian Orogen (515-490 Ma), Lachlan Fold Belt (485-340 Ma), and New England Orogen (305-230 Ma), collectively referred to as the "Tasmanides", which record a protracted period of arc-related magmatic activity throughout the Paleozoic to Early Mesozoic (Fig. 1; Betts et al., 2002; Glen, 2005; Kemp et al., 2007). Terranes equivalent with the Tasmanides of eastern Australia are present in Marie Byrd Land of Antarctica but not from present-day East Antarctica that adjoined SW Australia during the LPIA (Veevers, 2004). Carboniferous plutons and volcanics are associated with incipient rifting between Australia and India/Himalaya in northern India (Veevers and Tewari, 1995). Phanerozoic detrital zircons from the Permian (Artinskian to Roadian) of the Perth Basin were inferred by Cawood and Nemchin (2000) as having a probable western or southern source, although specific terranes were not named.

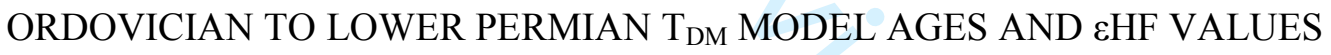

Hf isotope data for Ordovician to Early Permian detrital zircons suggests their sources formed from both relatively juvenile, mantle-derived crust and older, more evolved Proterozoic crust (Table 5; Fig. 9). To our knowledge, there is no published Hf or $\mathrm{Nd}$ data from potential Paleozoic source terranes near the Canning Basin. Hf isotope data from various Tasmanide units have yielded a variety of $\varepsilon \mathrm{Hf}$ values ranging from highly positive to negative similar to those recorded from Canning Basin detrital zircons (Belousova et al., 2006; Hawkesworth and Kemp, 2006; Offler and Shaw, 2006; Kemp et al., 2007). However, very low $\varepsilon H f$ values have not been reported from the Tasmanides (e.g. Betts et al., 2002). Furthermore, Kemp et al. (2007) reported increasingly juvenile isotopic compositions from the Delemarian Orogeny adjacent to cratons towards the outboard and younger New England Orogeny that contains 
minimal cratonic material. This suggests the youngest Grant Group detrital zircons with ages equivalent to the earliest stages of the New England Orogeny were most likely derived from more isotopically-evolved source terranes, such as late intrusions associated with the Alice Springs Orogeny in central Australia (e.g. Buick et al., 2008).

\section{IMPLICATIONS FOR SOURCE AREA CORRELATION}

Detrital zircon $\mathrm{U}-\mathrm{Pb}$ ages are broadly equivalent with Ordovician to Late Carboniferous metamorphic and igneous events of central Australia, particularly in the Arunta Inlier, as well as Tasmanide events in eastern Australia. Grant Group Hf isotope data overlap with both these potential source areas but the presence of young zircons that originated from evolved crust suggests an Arunta Inlier source area is more likely.

\section{DISCUSSION}

\section{Correlation of detrital zircons with potential source areas}

EASTERN SOURCE AREAS

Paleo- and Mesoproterozoic detrital zircons with $\mathrm{Pb}-\mathrm{Pb}$ crystallization ages between c.1870-1450 and 1375-1035 Ma dominate the three samples. These $\mathrm{Pb}-\mathrm{Pb}$ ages, together with associated $\varepsilon \mathrm{Hf}$ and $\mathrm{Hf}$ model ages, are widely comparable to published data from the Arunta Inlier and Musgrave Block suggesting eastern basement terranes were the principal source areas for the Grant Group in the northern Canning Basin. Remaining uncertainties include whether Paleoproterozoic zircons from the Rudall Complex have a similar or different 
Hf-isotopic signature to those from the Arunta Inlier, and the source of a minor population of Mesoproterozoic detrital zircons with a $\mathrm{Lu}-\mathrm{Hf}$ composition more evolved than that reported from the Musgrave Block. Alternative source areas with similar Mesoproterozoic crystallization ages include the Kimberley, Arunta and Rudall basement terranes. Further Lu-Hf or $\mathrm{Sm}-\mathrm{Nd}$ dating of these terranes is required to adequately address these provenance uncertainties.

Further evidence for eastern basement terranes being principal source areas is the population of late Paleozoic detrital zircons in all samples, which is consistent with measurements from striated pavements measurements showing paleo-ice flow to the west in central Australia (Haines et al., 2011). Sediment eroded and entrained within ice eroding the central Australian uplands were subsequently deposited within proglacial environments with an axial component of sediment routing along the NW-SE Fitzroy Trough (as shown by paleocurrents recorded from Grant Group outcrops along the Fitzroy River; Fig. 4). Detrital zircon U-Pb ages are broadly equivalent with the timing of Ordovician to latest Carboniferous metamorphic and igneous events of central Australia, particularly those of the Alice Springs Orogeny recorded within the Arunta Inlier. Comparable Paleozoic zircon-forming events are unknown elsewhere in Western Australia. The closest alternative source areas lie farther east and associated with the orogenic events related with subduction along Australia's paleo-Pacific margin recorded within the Delamarian, Lachlan and New England orogens (e.g. Betts et al., 2002; Glen, 2005). Whereas Hf isotope data for these young detrital zircons are partly comparable with eastern basement terranes (Belousova et al., 2006; Hawkesworth and Kemp, 2006; Offler and Shaw, 2006; Kemp et al., 2007), the $\varepsilon H f$ and Hf model ages for the Grant Group samples reveal a more evolved crustal signature unlike that in eastern Australia but consistent with the Arunta Inlier. 


\section{SOUTHERN SOURCE AREAS}

Despite striated pavements clearly indicating that an Early Permian ice sheet advanced northwards from the Pilbara-Yilgarn cratons into the Canning Basin (e.g. Fig. 2A), detrital zircons with Archean ages constitute only a minor component of the total dataset. It is not possible to differentiate between Archean source areas to the south and reworked detrital grains from the north (Kimberley) based on $\mathrm{U}-\mathrm{Pb}$ ages alone. Hf data from several Grant zircons are similar to published data from the Pilbara-Yilgarn cratons, raising the possibility they were ultimately sourced from that region (Fig. 11). However, it is apparent that Archean cratons were not significant source areas for the Grant Group in the northern Canning Basin. There is also a similar paucity in Archean detrital zircons from younger, post-glacial Permian successions of the Perth Basin (Artinskian Irwin River Coal Measures; Cawood and Nemchin, 2000; and Artinskian to Wuchiapingian Collie Coal Measures; Veevers et al., 2005), despite their proximity to the Yilgarn Craton. Nevertheless, Dillinger et al. (2018) found significant Archean zircons in samples from the Irwin River Coal Measures but only in those close to the Yilgarn Craton. Apatite fission track studies demonstrate a regional cooling episode over the northern Yilgarn Craton that commenced in the Late Carboniferous to Early Permian and continued until the Late Jurassic to Early Cretaceous times, which suggests several kilometres of denudation of sedimentary cover overlying the craton (Kohn et al., 2002; Weber et al., 2005). The paucity of Archean detrital zircons in the northern Canning Basin samples may therefore be due to the Pilbara Craton not being exposed during deposition of the Grant Group. Possible alternative explanations are: Archean zircons from south of the Canning Basin were transported into areas now situated offshore NW Australia (consistent with directions measured from striae in the Pilbara), or not transported farther north than the Kidson 


\begin{abstract}
Sub-basin, or their relative abundance in the northern Canning Basin was diluted by the volume of detritus eroded from central Australian cratonic areas during Carboniferous uplift.
\end{abstract}

\title{
NORTHERN SOURCE AREAS
}

Generally, there are few detrital zircons in this dataset that can be correlated confidently with basement terranes north of the Canning Basin. The notable exception is the small population of c. 1890-1865 Ma detrital zircons in sample CYC that are equivalent to the Hooper Orogeny ages in the Halls Creek and King Leopold orogens, and the Nimbuwah Event in the Pine Creek Orogen. Their absence in samples DRO and CAP, from the Crossland Platform and Barbwire Terrace, implies sediment routing from the north did not extend farther south than the Fitzroy Trough, which is consistent with the structural configuration of the basin. However, this apparent paucity of northern source area detritus contradicts seismic evidence for major glacially incised valleys and associated channel systems along the northern margins of the Canning Basin (e.g. O’Brien et al., 1998; Al-Hinaai \& Redfern, 2015) and in the southern Bonaparte Basin (Gorter et al., 2008). Further sampling from locations within the Lennard Shelf and Fitzroy Trough is required to identify and understand lateral sediment input routes into the basin.

\section{Implications for scale and timing of Early Permian glaciation in Australia}

There is abundant stratigraphic, sedimentological and seismic evidence for Early Permian glaciation in western and central Australian basins (Redfern, 1990; Martin et al., 2007; Gorter et al., 2008; Mory et al., 2008; Al-Hinaai \& Redfern, 2015). From these and the current study, it is clear that Early Permian ice sheets over different cratonic uplands of Western and central 
Australia advanced basinwards during glacial phases (Fig. 12B). This is contrary to earlier models that invoked a single continental-scale ice sheet that advanced northward across the region (e.g. Playford, 2002). It is not possible to determine if individual ice sheets coalesced during maxima phases but, for the Early Permian at least, these combined datasets suggest multiple rather than unidirectional paleo-ice transport directions across the Canning Basin towards the episodically marine Fitzroy Trough and presumably eventually into basinal areas now lying along the North West Shelf.

This interpretation is supported by data from eastern Australia that suggests limited or no glaciation in the late Pennsylvanian followed by protracted glaciation in the Early Permian spanning 299-290 Ma, interpreted by Fielding et al. (2008) as peak glaciation in eastern Australia. This is broadly consistent with two very low diversity brachiopod and bivalve faunal assemblages from the Asselian in eastern Australia (Waterhouse and Shi, 2013) Additionally, stable isotope data for the Early Permian indicate significant global cooling during the Asselian followed by deglaciation in the early Sakmarian. This data includes the ${ }^{87} \mathrm{Sr} /{ }^{86} \mathrm{Sr}$ seawater curve for the Permian which declines from a maximum in the Asselian through the Sakmarian (Korte et al., 2006), a trend similarly reflected by the $\delta^{18}$ O curve (Gradstein et al., 2012), and estimations of $\mathrm{pCO}_{2}$, which indicate maximum expansion of Gondwanan ice sheets in the Asselian (Montañez et al., 2007). Detrital zircon evidence for a continental-scale ice sheet in Australia outlined in this paper is consistent with these independent datasets and provides further evidence for significant climate cooling at the onset of, or just prior to, the Permian.

The youngest detrital zircons from this dataset provide a maximum depositional age for the glaciogenic Grant Group, thereby constraining the maximum age of continental ice sheet development. The youngest zircon from this dataset (cyc78b) has a ${ }^{206} \mathrm{~Pb}^{*} /{ }^{238} \mathrm{U}$ age of $297 \pm 7 \mathrm{Ma}(2 \sigma, 91 \%$ concordant; Table 2$)$, giving an imprecise maximum range of late Kasimovian to Asselian. The youngest zircons from sample CAP (cap44b and cap103a) have a 
weighted average ${ }^{206} \mathrm{~Pb}^{*} / 238 \mathrm{U}$ age of $303.8 \pm 2.8 \mathrm{Ma}$, giving a maximum age range of Kasimovian to Gzhelian (Fig. 10). These Grant Group samples therefore constrain the onset of contemporaneous glaciation to a maximum age of Kasimovian, but possibly ranging into the Asselian. In the future, more and increasingly accurate zircon dating methodologies should be able to constrain this better (e.g. Griffis et al., 2018).

Timing of deglaciation is constrained by the biostratigraphic age of the ?Gzhelian to lower Sakmarian Grant Group (P. confluens and possibly M. tentula palynozones; Apak and Backhouse, 1998, 1999; Mory, 2010), with an upper limit provided by the overlying postglacial upper Sakmarian to Artinskian Poole Sandstone (P. pseudoreticulata and S. fucus palynozones; Archbold, 1999; Haig et al., 2014). The boundary between $P$. confluens and $P$. pseudoreticulata corresponds with an absolute age of c. 290 Ma, making the Grant Group broadly equivalent with Fielding et al.'s (2008) P1 glacial phase in eastern Australia (Fig. 3). Deglaciation was marked by extensive proglacial sedimentation as glacial detritus previously stored in the ice sheets was carried by meltwaters into basinal areas. Up to several kilometres of Lower Permian glacial successions, including the Grant Group, are preserved in Western Australian basins and attest to significant influx of glacial meltwater and sediment (Mory et al., 2008). There is only limited evidence for glacial conditions persisting beyond the Sakmarian in Western Australia. Eyles et al. (2006) reported ice-rafted debris and cold-water fauna within mudstones of the Carynginia Formation (Kungurian) of the Perth Basin, and Haig et al. (2017) noted dropstones in equivalent strata from the Southern Carnarvon Basin, implying a seasonally cold climate. This contrasts with eastern Australia, where three discrete glacial epochs following peak glaciation in the Early Permian are identified across several basins in New South Wales and Queensland (e.g. Sydney, Bowen and Gunnedah basins) with glaciomarine deposits containing ice-rafted debris and glendonites in strata as young as Capitanian (Jones et al., 2006; Birgenheier et al., 2007; Fielding et al., 2008). Furthermore, Water- 
house and Shi (2013) were able to define six cold Permian climatic periods up to the Changhsingian from low diversity faunal assemblages in eastern Australia and New Zealand.

\section{Implications for scale and timing of Carboniferous glaciation in Australia}

Current regional models for the LPIA in eastern Australian basins show four discrete glacial phases between the c. Serpukhovian and Moscovian followed by a Kasimovian-Gzhelian inter-glacial phase, based on sedimentological and biostratigraphic data with absolute ages partially constrained by U-Pb dating of tuffs (Roberts et al., 1995; Jones and Fielding, 2004; Fielding et al., 2008). In central and Western Australian basins, onset of mid-Carboniferous (c. Visean) ice sheet growth is inferred from the timing of central Australian uplift associated with the Alice Springs Orogeny, palynological ages based dating of possible glaciogenic successions and associated lacunas, and far-field cyclothemic sedimentations patterns (Eyles et al., 2006; Veevers, 2009). However, although these are valid circumstantial reasons to explain the onset of glaciation in the mid-Carboniferous, there is very limited direct evidence for glaciation reported, such as classic glacial sedimentary facies, nor are there any absolute age constraints such as those applied in eastern Australia and elsewhere in Gondwana (e.g. Griffis et al., 2018). This issue is compounded by an apparent absence of tuffs or other intraformational volcanics within mid-Carboniferous successions of western and central Australian basins. Some Western Australian post-glacial successions do have dateable volcanics, but these are stratigraphically younger and do not yet provide age constraints on the LPIA (Mory et al., 2017).

Currently, there is very limited evidence for Carboniferous glaciation in the Canning Basin. Seismic interpretation suggests the Reeves Formation is a fluvial-dominated, syn-rift rather than a sensu stricto glacial succession (Al Hinaai \& Redfern, 2015). The Reeves For- 
mation is restricted to a limited number of sub-surface sections in petroleum wells with minimal core available. Lithological and wireline log data from these wells indicate the Reeves Formation is composed predominantly of homogeneous sandstone with minor intervening silt- and mudstone. 'Direct' evidence for glaciation (e.g. diamictites or varved units with dropstones or striated clasts) has not been identified. The partly coeval Visean to Sakmarian Nangetty Formation of the Perth Basin contains speculated Carboniferous glacial deposits in Western Australia (Eyles et al., 2006), thus it is possible the Reeves Formation represents a well-sorted, distal proglacial succession. However, not only has the glacial affinity of the Carboniferous succession in the Perth Basin been questioned by Playford \& Mory (2017), but it is unclear if that basin contains any lower to mid-Pennsylvanian strata. In the southeastern Bonaparte Basin strata coeval with the Reeves Formation (Wadeye Group) are considered possibly glaciogenic but there is little definitive evidence for this (Gorter et al., 2005). Consequently, until further sedimentological and biostratigraphic data becomes available, models for middle to Late Carboniferous glaciation in the Canning Basin and the wider region remain speculative (Fig. 12A).

\section{Alternative regional glaciation models}

The present detrital zircon dataset provides new stratigraphic constraints on the LPIA in the Canning Basin and surrounding region but, as discussed above, there remains significant uncertainty in the absolute ages of glaciogenic successions in western and central Australia. Until these are better resolved with more accurate dating techniques (e.g. Bodorokos et al., 2016), there remains scope for different regional glaciation models to be considered. There are essentially two end-member models; firstly, one where the main phase of continental ice sheet growth was in the Pennsylvanian prior to Early Permian deglaciation, and secondly, one 
where both the main phase of continental ice sheet growth and deglaciation was during the latest Carboniferous to Early Permian. The challenge for the former is the highly fragmented and poorly exposed Carboniferous stratigraphic record in this region seriously limits the availability of direct evidence for glaciation during this period. Consequently, it is only via circumstantial evidence such as widespread lacunas (e.g. Veevers, 2009) and climatic indicators from relatively far-field outcrops (e.g. Davydov et al., 2013) that models for Pennsylvanian ice sheet growth in this region can be explained. The challenge for the latter is that preservation bias associated with better evidence of younger glaciations likely causes any evidence for former glaciations to be overlooked. There are also challenges related with what is preserved in ancient glaciogenic successions, which in many cases are marineinfluenced and/or deglaciation-related (e.g. Eyles, 1993; Pedersen, 2012), thus leaving much room for interpreting when and how many phases of ice advance there were (cf. Assine et al., 2018; Le Heron, 2018). This is certainly the case for the Grant Group, although there are sedimentological and seismic lines of evidence for more than one phase of ice advance and retreat. This detrital zircon study overall suggests a model of continental ice sheet growth in the Asselian when considered in wider context, but the youngest zircons imply this could have been in the Kasimovian or Gzhelian, which is broadly consistent with estimated timings of peak glaciation elsewhere in Gondwana (e.g. Isbell et al., 2012; Montanez \& Poulsen, 2013). Pending future improved absolute age constraints on Carboniferous palynozones, this could explain, at least in part, the large time gap between the Reeves Formation and the Grant Group (Fig. 3). However, this would be contrary to evidence for regional climatic warming in the late Pennsylvanian (Fielding et al., 2008; Davydov et al., 2013). A third regional glaciation model scenario with significant continental ice sheet growth in both the midCarboniferous and Early Permian incorporating an intervening late Pennsylvanian interglacial period is also plausible, but beyond the scope of this study. 
Key to improving our understanding will be further evaluation of the glacial affinity of the thick Carboniferous subsurface successions preserved in the onshore and marine basins of Western Australia due to the paucity of equivalent outcrop exposures. There are, however, relatively few Carboniferous well penetrations, so seismic reflection data will be important for mapping sequence and stratigraphic architecture to identify possible glacial related phenomena, such as the Permian glacial valleys identified in the Canning Basin (Al-Hinaai \& Redfern, 2015), and in the Bonaparte Basin (Gorter et al., 2008). Petrographic and other techniques investigating rock microstructure, such as CT scanning, could also be useful in identifying glacial textures considering the paucity of outcrops (e.g. Woronko, 2016). Further radiometric age dating is also critical to improve the resolution of the LPIA stratigraphic record and regional glaciation models for Australia, which is currently largely based upon long-ranging, imprecise palynological zonations in the west (Apak \& Backhouse, 1998, 1999; Mory, 2010) and SHRIMP U-Pb ages in the east (e.g., Roberts et al., 1995, fig. 13; 2006, fig. 10). Without robust absolute ages, it has long been recognized that provincial flora and fauna such as these are difficult to correlate with global equivalent successions (Mory et al., 2008). Furthermore, correlation and age control for eastern Australia successions, which is mostly provided by SHRIMP U-Pb zircon dates from interbedded volcanic intervals (e.g., Roberts et al., 1995), is also contentious given errors typically about \pm 3 Ma and the distance between sections. Haig et al. (2017) suggest Permian correlations in eastern Australia require CA-IDTIMS dating to be resolved, a point that seemingly applies equally well to Upper Carboniferous in that region, as well as sections elsewhere in Australia.

\section{CONCLUSIONS}


Detrital zircons from the Grant Group in the northern Canning Basin were principally sourced from basement terranes in central Australia, notably the Arunta Inlier and Musgrave Province, with a significant component likely recycled from stratigraphic units eroded beneath the Base Grant Unconformity. There are also components that can be correlated with basement terranes to the south and to the north of the Canning Basin, but they are not considered as principal source areas on this detrital zircon dataset. Conversely, there is clear outcrop evidence for ice sheets over the Pilbara-Yilgarn cratons, and subsurface and other regional evidences for ice advance into the Canning Basin on both its southern and northern margins, which imply basement terranes in these areas could have been sediment source areas for the Grant Group. This discrepancy between provenance analysis and field and subsurface observations highlights the importance of evaluating regional glaciation models with an integrated dataset.

This study shows the effectiveness of combining $\mathrm{Hf}$ isotopes with $\mathrm{U}-\mathrm{Pb}$ dating to facilitate correlation with basement source areas with similar ages, which is essential in a study area with highly complex basement geology such as Western Australia, where individual detrital zircon crystallization ages are correlative with multiple candidate source areas. Equally important in such areas is a comprehensive geochronological database of basement areas for high confidence correlation with detrital zircons, with some residual correlation uncertainties in this provenance study due to the paucity of Hf or Nd isotope data in some basement terranes.

The youngest Grant Group detrital zircons constrain contemporaneous ice sheet development in western and central Australian uplands to a maximum late Pennsylvanian (Kasimovian) age, whereas palynology constrains a minimum Sakmarian age. The latest Pennsylvanian to early Sakmarian palynological age of the Grant Group provides a minimum duration for the presence of these ice sheets over some of these uplands, with remaining uncertainty on their earlier presence (Fig. 12B). A model is proposed where the main phase of 
continental ice sheet growth was in the Asselian, consistent with the LPIA evolution in eastern Australia (Fielding et al., 2008), as well as global climate proxies that indicate significant global cooling during this time (e.g. Gradstein et al., 2012; Korte et al., 2006; Montañez et al., 2007). The presence of ice sheets or glaciers older than Kasimovian in western Australia remains possible, particularly in upland areas flanking the Perth Basin (Eyles et al., 2006; Fig. 12A), but there is no direct evidence for Carboniferous glaciation in the Canning Basin, nor for significant glaciations younger than the Sakmarian. The caveat to this is the fragmentary nature of the glacial stratigraphic record whereby continental glacial deposits and associated erosional phenomena have very low preservation potential ( $<5 \%$ according to Eyles, 1993) due to multiple phases of ice advance and retreat, with the youngest glacial phases of any ice age clearly having greater chance of preservation.

\section{ACKNOWLEDGEMENTS}

This study was jointly funded by a Natural Environmental Research Council (UK) Studentship NER/S/A/2004/13012 and Shell International Exploration and Production (Netherlands). Thanks are due to the staff of the Western Australian Carlisle core facility (Department of Industry Regulation and Safety, Perth) for their assistance during sampling, C. Davies, H. Lock, D. Plant and V. Pashley for their help with mineral separation, CL imaging, and data acquisition, and K. Ludwig for providing a copy of Isoplot. AJM publishes with the permission of the Director, Geoscience and Resource Strategy Division, Department of Mines, Industry Regulation and Safety, Western Australia. D. Le Heron and an anonymous reviewer are thanked for their suggestions that improved this manuscript. 


\section{REFERENCES}

Aitken, A.R. \& Betts, P.G. (2009). Constraints on the Proterozoic supercontinent cycle from the structural evolution of the south-central Musgrave Province, central Australia. Precambrian Research, 168, 284-300.

Al-Hinaai, J. (2013). Constraining the structural evolution of the Canning Basin, NW Australia, and controls on Permo-Carboniferous ice sheets development. Ph.D. thesis, University of Manchester, UK.

Al-Hinaai, J. \& Redfern J. (2015). Tectonic and climatic controls on the deposition of the Permo-Carboniferous Grant Group and Reeves Formation in the Fitzroy Trough, Canning Basin, Western Australia. Marine and Petroleum Geology, 59, 217-231.

Apak, S.N. \& Backhouse, J. (1998). Re-interpretation of the Permo-Carboniferous succession, Canning Basin, Western Australia. In P.G. Purcell and R.R. Purcell (Eds.), The sedimentary basins of Western Australia 2: proceedings of the Petroleum Exploration Society of Australia (pp. 683-694). Perth, Australia.

Apak, S.N. \& Backhouse, J. (1999). Stratigraphy and petroleum exploration objectives of the Permo-Carboniferous succession on the Barbwire Terrace and adjacent areas, northeast Canning Basin, Western Australia. Geological Society of Western Australia, Report 68, Perth, Australia.

Archbold, N.W. (1995). Studies on Western Australian brachiopods 12, additions to the late Asselian-Tastubian faunas. Proceedings of the Royal Society of Victoria, 107, 95-112.

Archbold, N.W. (1999). Permian Gondwanan correlations: the significance of the Western 
Australian marine Permian. Journal of African Earth Sciences, 29, 63-75.

Archbold, N.W. \& Shi, G.R. (1995). Permian brachiopods of Western Australia: GondwananAsian relationships and Permian climate. Journal of Southeast Asian Earth Sciences, $11,207-215$.

Assine, M.L., de Santa Ana, H., Veroslavsky, G., \& Vesely, F.F. (2018). Exhumed subglacial landscape in Uruguay: Erosional landforms, depositional environments, and paleo-ice flow in the context of the late Paleozoic Gondwanan glaciation. Sedimentary Geology, 369, 1-12.

Backhouse, J. (1992). Palynology of four samples from Newcrest Mining Limited, Borehole HAC 9201, Western Canning Basin. Geological Survey of Western Australia Paleontological Report, Perth, Australia.

Bagas, L. (2004). Proterozoic evolution and tectonic setting of the northwest Paterson Orogen, Western Australia. Precambrian Research, 128, 475-496.

Belousova, E.A., Griffin, W.L. \& O'Reilly, S.Y. (2006). Zircon crystal morphology, trace element signatures and Hf isotope composition as a tool for petrogenetic modelling: examples from eastern Australian granitoids. Journal of Petrology, 47, 329-353.

Betts, P.G., Giles, D., Lister, G.S. \& Frick, L.R. (2002). Evolution of the Australian lithosphere. Australian Journal of Earth Sciences, 49, 661-695.

Betts, P.G., Giles, D., Mark, G., Lister, G. S., Goleby, B. R., \& Aillères, L. (2006). Synthesis of the Proterozoic evolution of the Mt Isa Inlier. Australian Journal of Earth Sciences, $53,187-211$.

Birgenheier, L.P., Fielding, C.R., Frank, T.D. \& Rygel, M.C. (2007). Nested cyclicity in the 
Carboniferous glacial record of New South Wales, Australia. AAPG Annual Conference Abstracts, Long Beach, California.

Black, L.P., Kamo, S.L., Williams, I.S., Mundil, R., Davis, D.W., Korsch, R.J., \& Foudoulis, C. (2003). The application of SHRIMP to Phanerozoic geochronology; a critical appraisal of four zircon standards. Chemical Geology, 200, 171-188.

Blatchford, T. (1927). The geology of portions of the Kimberley Division, with special reference to the Fitzroy Basin and the possibilities of the occurrence of mineral oil. Geological Survey of Western Australia, Bulletin 93, Perth, Australia.

Bodorokos, S., Oliver, N.H.S. \& Cawood, P.A. (1999). Thermal evolution of the central Halls Creek Orogen, northern Australia. Australian Journal of Earth Sciences, 46, 453-465.

Bodorkos, S., Crowley, J., Holmes, E., Laurie, J., Mantle, D., McKellar, J., Mory, A.J., Nicoll, R., Phillips, L., Smith, T., Stephenson, M. \& Wood, G. (2016). New dates for Permian palynostratigraphic biozones in the Sydney, Gunnedah, Bowen, Galilee and Canning basins, Australia. Permophiles, 63, 19-21.

Bruguier, O., Bosch, D., Pidgeon, R.T., Byrne, D.I. \& Harris, L.B. (1999). U-Pb chronology of the Northampton Complex, Western Australia - evidence for Grenvillian sedimentation, metamorphism and deformation and geodynamic implications. Contributions to Mineralogy and Petrology, 136, 258-272.

Buatois, L.A., Netto, R.G., Mangano, M.G. \& Balistieri, P.R.M.N. (2006). Extreme freshwater release during the late Paleozoic Gondwanan deglaciation and its impact on coastal ecosystems. Geology, 34, 1021-1024.

Buick, I.S., Miller, J.A., Williams, I.S. \& Cartwright, I. (2001). Ordovician high-grade meta- 
morphism of a newly recognised late Neoproterozoic terrane in the northern Harts Range, central Australia. Journal of Metamorphic Geology, 19, 373-394.

Buick, I.S., Hand, M., Williams, I.S., Maybe, J., Miller, J.A. \& Nicole, R.S. (2005). Detrital zircon provenance constraints on the evolution of the Harts Range Metamorphic Complex (central Australia): links to the Centralian Superbasin. Journal of the Geological Society of London, 162, 777-787.

Buick, I.S., Storkey, A. \& Williams, I.S. (2008). Timing relationships between pegmatite emplacement, metamorphism and deformation during the intra-plate Alice Springs Orogeny, central Australia. Journal of Metamorphic Geology, 26, 915-936.

Camacho, A. \& Fanning, C.M. (1995). Some isotopic constraints on the evolution of the granulite and Late amphibolite facies terranes in the eastern Musgrave Block, central Australia. Precambrian Research, 71, 155-181.

Cawood, P.A. \& Nemchin, A.A. (2000). Provenance record of a rift basin: U-Pb ages of detrital zircons from the Perth Basin, Western Australia. Sedimentary Geology, 134, 209-234.

Cawood, P.A. \& Tyler, I.M. (2004). Assembling and reactivating the Proterozoic Capricorn Orogen: lithotectonic elements, orogenies and significance. Precambrian Research, $128,201-218$.

Claoué-Long, J., Edgoose, C. \& Worden, K. (2008). A correlation of Aileron Province stratigraphy in central Australia. Precambrian Research, 166, 230-245.

Collins, A.S. (2003). Structure and age of the northern Leeuwin Complex, Western Australia: constraints from field mapping and $\mathrm{U}-\mathrm{Pb}$ isotopic analysis. Australian Journal of 
Earth Sciences, 50, 585-599.

Collins, W.J., Williams, I.S., Shaw, S.E. \& McLaughlin, N.A. (1995). The age of the Ormiston Pound Granite: implications for Mesoproterozoic evolution of the Arunta Inlier, central Australia. Precambrian Research, 1995, 91-105.

Corfu, F., Hanchar, J.M., Hoskin, P.W.O. \& Kinny, P. (2003). Atlas of zircon textures. Reviews in Mineralogy and Geochemistry, 53, 469-500.

Crowe, R.W.A. \& Towner, R.R. (1976). Definitions of some new and revised rock units in the Canning Basin. Geological Society of Western Australia, Record 1976/24, Perth, Australia.

Crowell, J.C. \& Frakes, L.A. (1975). The Late Paleozoic Glaciation. In Campbell, K.S.W. (Ed.), Gondwanan Geology (pp. 313-331). Australian National University Press, Canberra, Australia.

Davydov, V.I., Haig, D.W. \& McCartain, E. (2013). A latest Carboniferous warming spike recorded by a fusulinid-rich bioherm in Timor Leste: implications for East Gondwana deglaciation. Paleogeography, Paleoclimatology, Paleoecology, 376, 22-38.

de Vries, S.T., Pryler, L.L. \& Fry, N. (2008). Evolution of Neoarchaean and Proterozoic basins of Australia. Precambrian Research, 166, 39-53.

\author{
Dillinger, A., George, A.D., \& Parra-Avila, L.A. (2018). Early Permian sediment prove- \\ nance and paleogeographic reconstructions in southeastern Gondwana using de- \\ trital zircon geochronology (Northern Perth Basin, Western Australia). Gondwa- \\ na Research, 59, 57-75.
}

Downes, P.J., Griffin, B.J. \& Griffin, W.L. (2007). Mineral chemistry and zircon geochronol- 
ogy of xenocrysts and altered mantle and crustal xenoliths from the Aries micaceous kimberlite: Constraints on the composition and age of the central Kimberley Craton, Western Australia. Lithos, 93, 175-198.

Evans, D.J.A. \& Benn, D.I. (2004). A practical guide to the study of glacial sediments. Arnold, London, UK.

Evins, P.M., Smithies, R.H., Howard, H.M., Kirkland, C.L., Wingate, M.T.D. \& Bodorokos, S. (2010). Devil in the detail; The 1150-1000Ma magmatic and structural evolution of the Ngaanyatjarra Rift, west Musgrave Province, Central Australia. Precambrian Research, 183, 572-288.

Eyles, C.H. \& Eyles, N. (2000). Subaqueous mass flow origin for Early Permian diamictites and associated facies of the Grant Group, Barbwire Terrace, Canning Basin, Western Australia. Sedimentology, 47, 343-356.

Eyles, N. (1993). Earth's glacial record and its tectonic setting. Earth-Science Reviews, 35, $1-248$.

Eyles, N. \& de Broekert, P. (2001). Glacial tunnel valleys in the Eastern Goldfields of Western Australia cut below the Late Paleozoic Pilbara ice sheet. Paleogeography, Paleoclimatology, Paleoecology, 171, 29-40.

Eyles, N., Mory, A.J. \& Backhouse, J. (2002). Carboniferous-Permian palynostratigraphy of west Australian marine rift basins: resolving tectonic and eustatic controls during Gondwanan glaciations. Paleogeography, Paleoclimatology, Paleoecology, 184, $305-319$.

Eyles, N., Mory, A.J. \& Eyles, C.H. (2006). 50-million-year-long record of glacial to postgla- 
cial marine environments preserved in a Carboniferous-Early Permian graben, northern Perth Basin, Western Australia. Journal of Sedimentary Research, 76, 618-632.

Fedo, C.M., Sircombe, K.N. \& Rainbird, R.H. (2003). Detrital zircon analysis of the sedimentary record. Reviews in Mineralogy and Geochemistry, 53, 277-303.

Fielding, C.R., Frank, T.D. \& Isbell, J.L. (Eds.), 2008. Resolving the Late Paleozoic Ice Age in Time and Space. The Geological Society of America, Special Paper 441, USA.

Fielding, C.R., Frank, T.D., Birgenheier, L.P., Rygel, M.C., Jones, A.T. \& Roberts, J. (2008). Stratigraphic imprint of the Late Paleozoic Ice Age in eastern Australia: a record of alternating glacial and nonglacial climate regime. Journal of the Geological Society, London, 165, 129-140.

Fitzsimons, I.C.W. (2003). Proterozoic basement provinces of southern and southwestern Australia, and their correlation with Antarctica. In Yoshida, M., Windley, B.F., \& Dasgupta, S. (Eds.), Proterozoic East Gondwana: supercontinent assembly and breakup (pp. 93-130). Geological Society of London Special Publications, 26, UK.

Flowerdew, M.J., Millar, I.L., Curtis, M.L., Vaughan, A.P.M., Horstwood, M.S.A., Whitehouse, M.J. \& Fanning, C.M. (2007). Combined U-Pb geochronology and Hf isotope geochemistry of detrital zircons from early Paleozoic sedimentary rocks, Ellsworth-Whitmore Mountains block, Antarctica. Geological Society of America Bulletin, 119, 275-288.

Foster, C.B. \& Waterhouse, J.B. (1988). The Granulatisporites confluens Oppel-zone and Early Permian marine faunas from the Grant Formation on the Barbwire Terrace, Canning Basin, Western Australia. Australian Journal of Earth Sciences, 35, 135-157. 
Raymond, O.L., Liu, S., Gallagher, R., Zhang, W. \& Highet, L.M. (2012). 1:1 million scale Surface Geology map of Australia, Geoscience Australia.

Giles, D., Betts, P.G. \& Lister, G.S. (2004). 1.8-1.5 Ga links between the North and South Australian Cratons and the Early-Middle Proterozoic configuration of Australia. Tectonophysics, 380, 27-41.

Glen, R.A. (2005). The Tasmanides of eastern Australia. In Vaughan, A.P.M., Leat, P.T. \& Pankhurst, R.J. (Eds.), Terrane processes at the margins of Gondwana (pp. 23-96). Geological Society London Special Publications, 246, UK.

Gorter, J.D., Jones, P.J., Nicoll, R.S. \& Golding, C.J. (2005). A reappraisal of the Carboniferous stratigraphy and petroleum potential of the southeastern Bonaparte Basin (Petrel Sub-basin) northwestern Australia. APPEA Journal and Conference Proceedings, 45, 275-295.

Gorter, J.D., Pynter, S.E., Bayford, S.W. \& Caudullo, A. (2008). Glacially influenced petroleum plays in the Kulshill Group (late Carboniferous - early Permian) of the southeastern Bonaparte Basin, Western Australia. APPEA Journal and Conference Proceedings, 48, 69-113.

Gradstein, F.M., Ogg, J.G., Schmitz, M. \& Ogg, G. (2012). The Geologic Time Scale 2012. Cambridge University Press, Cambridge, UK.

Graham, S., Lambert, D.D., Shee, S.R., Smith, C.B. \& Reeves, S. (1999). Re-Os isotopic evidence for Archean lithospheric mantle beneath the Kimberley block, Western Australia. Geology, 27, 431-434.

Griffin, T.J., Page, R.W., Sheppard, S. \& Tyler, I.M. (2000). Tectonic implications of Paleo- 
proterozoic post-collisional, high-K felsic igneous rocks from the Kimberley region of northwestern Australia. Precambrian Research, 101, 1-23.

Griffin, W.L., Belousova, E.A., Shee, S.R., Pearson, N.J. \& O'Reilly, S.Y. (2004). Archean crustal evolution in the northern Yilgarn Craton: $\mathrm{U}-\mathrm{Pb}$ and Hf-isotope evidence from detrital zircons. Precambrian Research, 131, 231-282.

Griffin, W.L., Belousova, E.A., Walters, S.G. \& O'Reilly, S.Y. (2006). Archean and Proterozoic crustal evolution in the Eastern Succession of the Mt Isa district, Australia: U-Pb and Hf-isotope studies of detrital zircons. Australian Journal of Earth Sciences, 53, $125-149$.

Griffis, N.P., Mundil, R., Montanez, I.P., Isbell, I., Fedorchuk, N., Vesely, F., Iannuzzi, R. \& Yin, Q.-Z. (2018). A new stratigraphic framework built on U-Pb single-zircon TIMS ages and implications for the timing of the penultimate icehouse (Paraná Basin, Brazil). Geological Society of America Bulletin, 130, 848-858.

Hambrey, M.J. \& Harland, W.B. (1981). Earth's pre-Pleistocene glacial record. Cambridge University Press, Cambridge, UK.

Haig, D. W., McCartain, E., Mory, A. J., Borges, G., Davydov, V., Dixon, M., Ernst, A., Groflin, S., Hakansson, E., Keep, M., Dos Santos, Z., Shi, G.R., \& Soares, J. (2014). Postglacial Early Permian (late Sakmarian-early Artinskian) shallow-marine carbonate deposition along a $2000 \mathrm{~km}$ transect from Timor to west Australia. Paleogeography, Paleoclimatology, Paleoecology, 409, 180-204.

Haig, D.W., Mory, A. J., McCartain, E., Backhouse, J., Håkansson, E., Ernst, A., Nicoll, R.S., Shi, G.R., Evan, J.C., Davydov, V.I., Hunter, A.W., Keep, M., Martin, S.K., Peyrot, D., Kossavaya, O. \& Dos Santos, Z. (2017). Late Artinskian-Early Kungurian (Early 
Permian) warming and maximum marine flooding in the East Gondwana interior rift, Timor and Western Australia, and comparisons across East Gondwana. Paleogeography, Paleoclimatology, Paleoecology, 468, 88-121.

Haines, P.W., Allen, H.-J., Wingate, M.T.D., Kirkland, C.L. \& Hocking, R.M. (2011). Ice movement direction and detrital zircon provenance data for early Permian glacial deposits, Amadeus Basin, eastern Western Australia. In Hakansson, E. \& Trotter, J.A. (Eds.), Programme and abstracts, The XVII International Congress on the Carboniferous and Permian, Perth 3-8 July 2011 (pp. 63). Geological Survey of Western Australia, Record 2011/20, Perth, Australia.

Hand, M., Mawby, J., Kinny, P. \& Foden, J. (1999). U-Pb ages from the Harts Range, central Australia: evidence for early Ordovician extension and constraints on Carboniferous metamorphism. Journal of the Geological Society London, 156, 715-730.

Hawkesworth, C.J. \& Kemp, A.I.S. (2006). Using hafnium and oxygen isotopes in zircons to unravel the record of crustal evolution. Chemical Geology, 226, 144-162.

Hickman, A.H. (2004). Two contrasting granite-greenstone terrane in the Pilbara Craton, Australia:evidence for vertical and horizontal tectonic regimes prior to $2900 \mathrm{Ma}$. Precambrian Research, 131, 153-172.

Hoatson, D.M., Sun, S. \& Claoue-Long, J.C. (2005). Proterozoic mafic-ultramafic intrusions in the Arunta Region, central Australia part 1: geological setting and mineral potential. Precambrian Research, 142, 93-133.

Hollis J.A., Carson C.J. \& Glass L.M. (2009). SHRIMP U-Pb zircon geochronological evidence for Neoarchean basement in western Arnhem Land, northern Australia. Precambrian Research, 174, 364-380. 
Hollis, J.A., Glass, L.M., Carson, C.J., Kemp, A.I.S., Yaxley, G., Armstrong, R. \& Scherstén, A. (2010). U-Pb-Hf-O character of Neoarchean basement to the Pine Creek Orogen, North Australian craton. In Tyler, I. \& Knox-Robinson, C.M. (Eds.), Fifth International Archean Symposium Abstracts (pp. 65-67). Geological Survey of Western Australia, Perth, Australia.

Hollis J.A., Kirkland, C.L., Spaggiari, C.V., Tyler, I.M., Haines, P.W., Wingate, M.T.D., Belousova, E.A., \& Murphy, R.C. (2013). Zircon U-Pb-Hf isotope evidence for links between the Warumpi and Aileron Provinces, west Arunta region. Geological Survey of Western Australia, Record 2013/9, Perth, Australia.

Isbell, J.L., Lenaker, P.A., Askin, R.A., Miller, M.F. \& Babcock, L.E. (2003). Reevaluation of the timing and extent of late Paleozoic glaciation in Gondwana: role of the Transantarctic Mountains. Geology, 31, 977-980.

Isbell, J.L., Henry, L.C., Gulbranson, E.L., Limarino, C.O., Fraiser, M.L., Koch, Z.J., Ciccioli, P.L., \& Dineen, A.A. (2012). Glacial paradoxes during the late Paleozoic ice age: Evaluating the equilibrium line altitude as a control on glaciation. Gondwana Research, 22, 1-19.

Ito, H. (2010). Dating Single Zircon by Fission-Track and U-Pb Methods: a Case Study on a Granite at the Cooper Basin HFR Site, Australia. In Proceedings of the World Geothermal Congress 2010 (pp. 1-5), Bali, Indonesia.

Ivanic, T.J., Van Kranendonk, M.J., Kirkland, C.L., Wyche, S., Wingate, M.T.D. \& Belousova, E. (2013). Juvenile crust formation and recycling in the northern Murchison Domain, Yilgarn Craton: evidence from Hf isotopes and granite geochemistry. Geological Survey of Western Australia, Report 120, Perth, Australia. 
Joly, A., Dentith, M.C., Porwal, A., Spaggiari, C.V., Tyler, I.M. \& McCuaig, T.C. (2013). An integrated geological and geophysical study of the west Arunta Orogen and its mineral prospectivity. Geological Survey of Western Australia, Report 113, Perth, Australia.

Jones, A.T. \& Fielding, C.R. (2004). Sedimentological record of the late Paleozoic glaciation in Queensland, Australia. Geology, 32, 153-156.

Jones, A.T., Frank, T.D. \& Fielding, C.R. (2006). Cold climate in the eastern Australian mid to late Permian may reflect cold upwelling waters. Paleogeography, Paleoclimatology, Paleoecology, 237, 370-377.

Kemp, A.I.S., Hawkesworth, C.J., Foster, G.L., Paterson, B.A., Woodhead, J.D., Hergt, J.M., Gray, C.M., \& Whitehouse, M.J. (2007). Magmatic and crustal differentiation history of granitic rocks from Hf-O isotopes in zircon. Science, 315, 980-983.

Kemp, E.M., Balme, B.E., Helby, R.J., Kyle, R.A., Playford, G., \& Price, P.L. (1977). Carboniferous and Permian palynostratigraphy in Australia and Antarctica: a review. Bureau of Mineral Resources Journal of Australian Geology and Geophysics, 2, 177208.

Kennard, J.M., Jackson, M.J., Romine, K.K., Shaw, R.D. \& Southgate, P.N. (1994). Depositional sequences and associated petroleum systems of the Canning Basin, W.A. In Purcell, P.G. \& Purcell, R.R. (Eds.), The sedimentary basins of Western Australia, Proceedings of the Western Australian Basins Symposium (pp. 657-676). Petroleum Exploration Society of Australia, Perth, Australia.

Kinny, P. D., \& Maas, R. (2003). Lu-Hf and Sm-Nd isotope systems in zircon. Reviews in Mineralogy and Geochemistry, 53, 327-341. 
Kirkland, C.L., Smithies, R.H., Woodhouse, E., Howard, H.M., Wingate, M.T.D., Belousova, E.A., Cliff, J.B., Murphy, R.C. \& Spaggiari, C.V. (2012). A multi-isotopic approach to the crustal evolution of the west Musgrave Province, central Australia. Geological Survey of Western Australia, Report 115, Perth, Australia.

Kirkland, C.L., Johnson, S.P., Smithies, R.H., Hollis, J.A., Wingate, M.T.D., Tyler, I.M., Hickman, A.H., Cliff, J.B., Belousovan E.A., Murphyn R.C. \& Tessalina, S. (2013). The crustal evolution of the Rudall Province from an isotopic perspective. Geological Survey of Western Australia, Report 122, Perth, Australia.

Kohn, B.P., Gleadow, A.J.W., Brown, R.W., Gallagher, O'Sullivan, P.B. \& Foster, D.A. (2002). Shaping the Australian crust over the last 300 million years: insights from fission track thermotectonic imaging and denudational studies of key terranes. Australian Journal of Earth Sciences, 49, 697-717.

Korte, C., Jasper, T., Kozur, H.W. \& Veizer, J. (2006). ${ }^{87} \mathrm{Sr} /{ }^{86} \mathrm{Sr}$ record of Permian seawater. Paleogeography, Paleoclimatology, Paleoecology, 240, 89-107.

\section{Le Heron, D.P. (2018). An exhumed Paleozoic glacial landscape in Chad. Geology, 46, 91-94.}

Ludwig, K.R. (2003). User's manual for Isoplot 3.00: a geochronological toolkit for Microsoft Excel. Berkeley Geochronological Centre, Special Publication 4, USA.

Maboko, M.A.H., McDougall, I., Zeitler, P.K. \& Williams, I.S. (1992). Geochronological evidence for $\sim 530-550$ Ma juxtaposition of two Proterozoic metamorphic terranes in the Musgraves Ranges, central Australia. Australian Journal of Earth Sciences, 39, $457-471$. 
Maidment, D.W., Hands, M. \& Williams, I.S. (2005). Tectonic cycles in the Strangeways Metamorphic Complex, Arunta Inlier, central Australia: geochronological evidence for exhumation and basin formation between two high-grade metamorphic events. Australian Journal of Earth Sciences, 52, 205-215.

Martin, J.R., Redfern, J., Mory, A.J. \& Williams, B.P.J. (2007). Facies architecture and reservoir prediction in ancient glaciogenic sediments: a case study using integrated outcrop and subsurface studies of the Grant Group (Canning Basin, West Australia), AAPG Annual Conference, Long Beach, California.

Martin, J.R., 2008. Sedimentological and provenance constraints on the Late Paleozoic Gondwanan Ice Age in the Canning Basin (Western Australia) and Oman. Ph.D. thesis, The University of Manchester, UK.

Mawby, J., Hand, M. \& Foden, J. (1999). Sm-Nd evidence for high-grade Ordovician metamorphism in the Arunta Block, central Australia. Journal of Metamorphic Geology 17, 653-658.

Metcalfe, I. (1996). Gondwanaland dispersion, Asian accretion and evolution of Eastern Tethys. Australian Journal of Earth Sciences, 43, 605-623.

Metcalfe, I. (2013). Gondwana dispersion and Asian accretion: Tectonic and paleogeographic evolution of eastern Tethys. Journal of Asian Earth Sciences, 66, 1-33.

Montañez, I.P. Tabor, N.J., Niemeier, D., DiMichele, W.A., Frank, T.D., Fielding, C.R., Isbell, J.L., Birgenheier, L.P. \& Rygel, M.C. (2007). $\mathrm{CO}_{2}$-forced climate and vegetation instability during the late Paleozoic deglaciation. Science, 315, 87-91.

Montañez, I.P. \& Poulsen, C.J. (2013). The late Paleozoic ice age: an evolving paradigm. 


\section{Annual Review of Earth and Planetary Sciences, 41, 629-656.}

Mory, A.J. (2010). A review of mid-Carboniferous to Triassic stratigraphy, Canning Basin, Western Australia. Geological Survey of Western Australia, Report 107, Perth, Australia.

Mory, A.J., Martin, J.R. and Redfern, J. (2008). A review of Permo-Carboniferous glacial deposits in Western Australia. In Fielding, C.R., Frank, T.D. \& Isbell, J.L. (Eds.), Resolving the Late Paleozoic Ice Age in Time and Space (pp. 29-40). The Geological Society of America, Special Paper 441, USA.

Mory, A.J., Crowley, J.L., Backhouse, J., Nicole, R.S., Bryan, S.E., Lopez Martinez, M. \& Mantle, D.J. (2017). Apparent conflicting Roadian-Wordian (middle Permian) CAIDTIMS and palynology ages from the Canning Basin, Western Australia. Australian Journal of Earth Sciences, 64, 889-901.

Mulder, T. \& Alexander, J. (2001). The physical character of subaqueous sedimentary density flows and their deposits. Sedimentology, 48, 269-299.

Nelson, D.R., Myers, J.S. \& Nutman, A.P. (1995). Chronology and evolution of the Middle Proterozoic Albany-Fraser Orogen, Western Australia. Australian Journal of Earth Sciences, 42, 481-495.

Neumann, N.L. \& Fraser, G.L. (2007). Geochronological synthesis and Time-Space plots for Proterozoic Australia. Geoscience Australia, Record 2007/06, Australia.

O'Brien, P.E. \& Christie-Blick, N. (1992). Glacially grooved surfaces in the Grant Group, Grant Ranges, Canning Basin and the extent of late Paleozoic Pilbara ice sheets. BMR Journal of Australian Geology and Geophysics, 13, 87-92. 
O’Brien, P.E., Lindsay, J.F., Knauer, K., \& Sexton, M.J. (1998). Sequence stratigraphy of a sandstone-rich Permian glacial succession, Fitzroy Trough, Canning Basin, Western Australia. Australian Journal of Earth Sciences, 45, 533-545.

Occhipinti, S.A. \& Reddy, S.M. (2009). Neoproterozoic reworking of the Paleoproterozoic Capricorn Orogen of Western Australia and implications for the amalgamation of Rodinia. In Murphy, J. B., Keppie, J. D. \& Hynes, A. J. (Eds.), Ancient Orogens and Modern Analogues (pp. 445-456). Geological Society of London, Special Publication 327, UK.

Offler, R. \& Shaw, S. (2006). Hornblende gabbro block in serpentinite Melange, PeelManning Fault System, New South Wales, Australia: Lu-Hf and U-Pb isotopic evidence for mantle-derived, Late Ordovician igneous activity. Journal of Geology, 114, $211-230$.

Osterloff, P.A., Penney, R.A., Aitken, J.F., Clark, N.D. \& Al-Husseini, M.I. (2004). Depositional sequences of the Al Khlata Formation, subsurface Interior Oman. In AlHusseini, M.I. (Ed.), Carboniferous, Permian and early Triassic stratigraphy (pp. 61-81). GeoArabia, Special Publication 3, Gulf PetroLink, Bahrain.

Pedersen, S.A.S. (2012). Glaciodynamic sequence stratigraphy. In Huuse, M., Redfern, J., Le Heron, D.P., Dixon, R.J., Moscariello, A. \& Craig, J. (Eds.), Glaciogenic reservoirs and hydrocarbon systems (29-51). Geological Society of London, Special Publication $368, \mathrm{UK}$.

Playford, P. (2002). Paleokarst, pseudokarst, and sequence stratigraphy in Devonian reef sequences of the Canning Basin, Western Australia. In Keep, M. \& Moss, S.J. (Eds.), The sedimentary basin of Western Australia 3: Proceedings of the Petroleum Explora- 
tion Society of Australia Symposium (pp. 763-794), Perth, Western Australia.

Playford, P.E., Hocking, R.M. \& Cockbain, A.E. (2009). Devonian reef complexes of the Canning Basin, Western Australia. Geological Survey of Western Australia Bulletin 145, Perth, Australia.

Playford G. \& Mory, A.J. (2017). Composition and occurrence of the Grandispora maculosa zonal assemblage (Mississippian) in the subsurface of the Carnarvon Basin and the Coolcalalaya Sub-basin of Western Australia, and its Gondwanan distribution. Revista Italiana di Paleontologiia e Stratigrafia, 123, 275-318.

Redfern, J. (1990). The sedimentology and stratigraphy of the Permo-Carboniferous Grant Group, Barbwire Terrace, Canning Basin, Western Australia. Ph.D. thesis, University of Bristol, UK.

Redfern, J. \& Millward, E. (1994). A review of the sedimentology and stratigraphy of the Permo-Carboniferous Grant Group, Canning Basin, Western Australia. In Purcell, P.G. \& Purcell, R.R. (Eds.), The sedimentary basins of Western Australia, Proceedings of the Petroleum Exploration Society of Australia (pp. 753-756), Perth, Australia.

Redfern, J. \& Williams, B.P.J. (2002). Canning Basin Grant Group glaciogenic sediments: part of the Gondwanan Permo-Carboniferous hydrocarbon province. In Keep, M. \& Moss, S.J. (Eds.), The sedimentary basins of Western Australia 3, Proceedings of the West Australian basins symposium (pp. 851-871), Perth, Australia.

Roberts, J., Claoue-Long, J.C., Jones, P. \& Foster, C.B. (1995). SHRIMP zircon age control of Gondwanan sequences in Late Carboniferous and Early Permian Australia. In Dunnay, R.A. \& Hailwood, A.E. (Eds.), Non-biostratigraphical methods of dating and correlation (pp. 145-174). Geological Society London, Special Publication 89, UK. 
Roberts, J., Claoue-Long, J.C. \& Foster, C.B. (1996). SHRIMP dating of the Permian System of eastern Australia. Australian Journal of Earth Sciences, 43, 401-421.

Rubatto, D., Williams, I.S. \& Buick, I.S. (2001). Zircon and monazite response to prograde metamorphism in the Reynolds Range, central Australia. Contributions to Mineralogy and Petrology, 140, 458-468.

Schmidt, P.W., Williams, G.E. and Camacho, A., 2006. Assembly of proterozoic Australia: Implications of a revised pole for the similar to 1070 Ma Alcurra Dyke Swarm, central Australia. Geophysical Journal International, 167: 626-634.

Scrimgeour, I.R. \& Close, D.F. (1999). Regional high-pressure metamorphism during intracratonic deformation: the Petermann Orogeny, central Australia. Journal of Metamorphic Geology, 17, 557-572.

Sener, A.K., Young, C., Groves, D.I., Krapez, B. \& Fletcher, I.R. (2005). Major orogenic gold episode associated with Cordilleran-style tectonics related to the assembly of Paleoproterozoic Australia? Geology, 33, 225--228.

Sheppard, S., Griffin, T.J., Tyler, I.M. \& Page, R.W. (2001). High- and low-K granites and adakites at a Paleoproterozoic plate boundary in northwestern Australia. Journal of the Geological Society, London, 158, 547-560.

Sircombe, K.N. \& Freeman, M.J. (1999). Provenance of detrital zircons on the Western Australia coastline - implications for the geologic history of the Perth basin and denudation of the Yilgarn craton. Geology, 27, 879-882.

Sun, S., Warren, R.G. \& Shaw, R.D. (1995). Nd isotope study from the Arunta Inlier, central Australia: constraints on geological models and limitations of the method. Precambri- 
an Research, 71, 301-314.

Taboada, C.S., Mory, A.J., Shi, G.-R., Haig, D.W. \& Pinilla, M.K. (2015). An Early Permian brachiopod-gastropod fauna from the Calytrix Formation, Barbwire Terrace, Canning Basin, Western Australia. Alcheringa: an Australasian Journal of Paleontology, 39, $207-223$.

Tyler, I.M., Page, R.W. \& Griffin, T.J. (1999). Depositional age and provenance of the Marboo Formation from SHRIMP U-Pb zircon geochronology: Implications for the early Paleoproterozoic tectonic evolution of the Kimberley region, Western Australia. Precambrian Research, 95, 225-243.

Van Kronendonk, M.J., Smithies, R.H., Hickman, A.H. \& Champion, D.C. (2007). Review: secular tectonic evolution of Archean continental crust: interplay between horizontal and vertical processes in the formation of the Pilbara Craton, Australia. Terra Nova, 19, $1-38$.

Veevers, J.J. (2004). Gondwanaland from 650-500 Ma assembly through 320 Ma merger in Pangea to 185-100 Ma breakup: supercontinental tectonics via stratigraphy and radiometric dating. Earth-Science Reviews, 68, 1-132.

Veevers, J.J. (2009). Mid-Carboniferous Centralian uplift linked by U-Pb zircon chronology to the onset of Australian glaciation and glacio-eustasy. Australian Journal of Earth Sciences, 56, 711-717.

Veevers, J.J., Saeed, A., Belousova, E.A. \& Griffin, W.L. (2005). U-Pb ages and source composition by Hf-isotope and trace element analysis of detrital zircons in Permian sandstone and modern sand from southwestern Australia and a review of the paleogeo- 
graphical and denudational history of the Yilgarn Craton. Earth-Science Reviews, 68, 245-279.

Veevers, J.J. \& Tewari, R.C. (1995). Permian-Carboniferous and Permian-Triassic magmatism in the rift zone bordering the Tethyan margin of southern Pangea. Geology, 23, $467-470$.

Wade, B.P., Hand, M. \& Barovich, K.M. (2005). Nd isotopic and geochemical constraints on provenance of sedimentary rocks in the eastern Officer Basin, Australia: implications for the duration of the intracratonic Petermann Orogeny. Journal of the Geological Society London, 162, 513-530.

Wade, B.P., Barovich, K.M., Hand, M., Scrimgeour, I.R. \& Close, D.F. (2006). Evidence for early Mesoproterozoic arc magmatism in the Musgrave Block, central Australia: Implications for Proterozoic crustal growth and tectonic reconstructions of Australia. Journal of Geology, 114, 43-63.

Waterhouse, J.B. \& Shi, G.R. (2013). Climatic implications from the sequential changes in diversity and biogeographic affinities for brachiopods and bivalves in the Permian of eastern Australia and New Zealand. Gondwana Research, 24, 139-147.

Weber, U.B., Kohn, B.P., Gleadow, A.J.W. \& Nelson, D.R. (2005). Low temperature Phanerozoic history of the Northern Yilgarn Craton, Western Australia. Tectonophysics, 400, $127-151$.

White, R.W., Clarke, G.L. \& Nelson, D.R. (1999). SHRIMP U-Pb zircon dating of Grenvilleage events in the western part of the Musgrave Block, central Australia. Journal of Metamorphic Geology, 17, 465-481. 
Wilde, S.A. (1999). Evolution of the western margin of Australia during the Rodinian and Gondwanan Supercontinent cycles. Gondwana Research, 2, 481-499.

Williams, B.P.J., Wild, E.K. \& Suttill, R.J. (1987). Late Paleozoic cold-climate aeolianites, southern Cooper Basin, South Australia. In Frostick, L. \& Reid, I. (Eds.), Desert sediments: ancient and modern (pp. 233-249), Geological Society of London, Special Publication 35, UK.

Williams, I.R. (2007). Geology of the Yilgalong 1:100,000 scale geological map: explanatory notes. Geological Survey of Western Australia, Perth, Australia.

Worden K.E., Carson C.J., Scrimgeour I.R., Lally J., \& Doyle N. (2008). A revised Paleoproterozoic chronostratigraphy for the Pine Creek Orogen, northern Australia: Evidence from SHRIMP U-Pb zircon geochronology. Precambrian Research, 166, 122-144.

\section{Woronko, B. (2016). Frost weathering versus glacial grinding in the micromorphology of quartz sand grains: processes and geological implications. Sedimentary geolo- gy, 335, 103-119.}

Zhao, J-X. \& McCulloch, M.T. (1993). Sm-Nd mineral isochron ages of Late Proterozoic dyke swarms in Australia: evidence for two distinct events of mafic magmatism and crustal extension. Chemical Geology, 109, 341-354.

Zhao, J-X. \& McCulloch, M.T. (1995). Geochemical and Nd isotopic systematics of granites from the Arunta Inlier, central Australia: implications for Proterozoic crustal evolution. Precambrian Research, 71, 265-299.

Zhao, J-X., McCulloch, M.T. \& Bennett, V.C. (1992). Sm-Nd and U-Pb zircon isotopic constraints on the provenance of sediments from the Amadeus Basin, central Australia: 
evidence for REE fractionation. Geochimica et Cosmochimca Acta, 56, 921-940. 


\section{APPENDIX A: ZIRCON DATING METHODOLOGY}

Samples were crushed, sieved, and separated using gravitational and centrifugal heavy liquid techniques. Zircons were further separated from the heavy mineral fraction using Frantz magnetic techniques, hand picked randomly under a binocular microscope, mounted on an epoxy block and polished to expose an equatorial section. Every grain was imaged using cathodoluminescence $(\mathrm{CL})$ to identify compositional zonation and the ablation target area. $\mathrm{U}-\mathrm{Pb}$ ages were determined using an Elemental Axiom double focussing MC-ICPMS coupled to a New Wave Research Microprobe UP193SS nm, Nd:YAG laser ablation system, at the Natural Environment Research Council Isotope Geosciences Laboratory (NIGL), UK. Analytical procedure for $\mathrm{U}-\mathrm{Pb}$ dating using the Axiom is fully outlined in Horstwood et al. (2003). A minimum of $60 \mathrm{U}-\mathrm{Pb}$ ages was determined for each sample (Table 2); analysis of 60 grains provides a $95 \%$ probability of finding a population comprising $5 \%$ of the total (Dodson et al., 1988). Spot size and laser repetition rate were maintained at $50 \mu \mathrm{m}$ and $5 \mathrm{~Hz}$ generating c. 2.6-3.4 J.cm ${ }^{-2}$ per pulse, with ablated material transferred from the sample cell to the Axiom plasma source by argon. Elemental fractionation was minimized by adopting standard protocol such as ablating pits with a low aspect ratio and calculating $\mathrm{Pb} / \mathrm{U}$ ratios with reference to standard zircon 91500, which was analysed after every fifth detrital zircon analysis. Ages were calculated using the Isoplot add-in (Ludwig, 2003) for Microsoft Excel using the decay constants recommended by Steiger and Jäger (1977). Ages quoted in this paper are ${ }^{206} \mathrm{~Pb}^{*} / 238 \mathrm{U}$ for $<1000 \mathrm{Ma}$ and ${ }^{207} \mathrm{~Pb}^{*} /{ }^{206} \mathrm{~Pb} *$ for $>1000 \mathrm{Ma}$, with $2 \sigma$ error (Figs. 8 and 9). The ${ }^{204} \mathrm{~Pb}$ signal for each analysis was used to assess the amount of common $\mathrm{Pb}$ (Horstwood et al., 2003), with correction applied as necessary.

Hf isotope analyses were performed (Table 5) after $\mathrm{U}-\mathrm{Pb}$ geochronology using a Nu Plasma HR (Nu Instruments) MC-ICP-MS coupled to a UP193SS (New Wave Re- 
search) laser ablation system. Ablations were targeted adjacent to the U-Pb ablation spots where possible using CL images. Similar zones within the same grains were targeted for Hf analyses placement immediately adjacent to the pre-existing $\mathrm{U}-\mathrm{Pb}$ ablation pit was not possible (e.g. Fig. 5). The analytical methodology was modified after Woodhead et al. (2004) to allow for the use of the $\mathrm{U}-\mathrm{Pb}$ collector block on the Nu Plasma HR at NIGL. This collector block is limited to 7 central Faraday detectors for use with isotope systems other than $\mathrm{U}-\mathrm{Pb}$, necessitating the sacrifice of the ${ }^{180} \mathrm{Hf}$ and ${ }^{172} \mathrm{Yb}$ peaks. Only the ${ }^{178} \mathrm{Hf} /{ }^{177} \mathrm{Hf}$ stable isotope ratio is therefore used to monitor the accuracy of the Hf mass bias correction, whilst a modified ${ }^{176} \mathrm{Yb} /{ }^{173} \mathrm{Yb}$ ratio is determined prior to analysis through $\mathrm{Yb}$-doping of the JMC475 Hf isotope reference material. This characterizes the difference between $\mathrm{Hf}$ and $\mathrm{Yb}$ instrumental mass bias and allows correction of the ${ }^{176} \mathrm{Yb}$ isobaric interference through measurement of the ${ }^{173} \mathrm{Yb}$ peak, without the need to measure both the ${ }^{172} \mathrm{Yb}$ and ${ }^{173} \mathrm{Yb}$ peaks simultaneously. Peak jumping experiments to allow simultaneous $\mathrm{Yb}$ mass bias correction of the $\mathrm{Yb}$ isobaric interference correction show no difference within uncertainty to those data determined using the doping approach. Monitoring of the ${ }^{180} \mathrm{Hf} /{ }^{177} \mathrm{Hf}$ ratio through a dynamic acquisition also demonstrates accurate stable isotope values.

Mass spectrometer performance was checked each session by running reference material JMC475 with and without $\mathrm{Yb}$ doping. Session averages for corrected ${ }^{176} \mathrm{Hf} /{ }^{177} \mathrm{Hf}$ and ${ }^{178} \mathrm{Hf} /{ }^{177} \mathrm{Hf}$ were $0.282148-63+/-40-110 \mathrm{ppm}$ and $1.467210-38+/-10-32 \mathrm{ppm}$ 2SD respectively. Laser spot size and repetition rate were maintained at $50 \mu \mathrm{m}$ and $5 \mathrm{~Hz}$ respectively, using a fluence of $6-8 \mathrm{~J} . \mathrm{cm}^{-2}$ per pulse. Sample data were normalized relative to reference material 91500 assuming ${ }^{176} \mathrm{Hf} /{ }^{177} \mathrm{Hf}=0.282306$ (Woodhead et al., 2004). ${ }^{178} \mathrm{Hf} /{ }^{177} \mathrm{Hf}$ for 91500 gave session averages of 1.46724-27 with average reproducibility of c. 35ppm 2SD. Interferences on ${ }^{176} \mathrm{Hf}$ were corrected by measuring ${ }^{173} \mathrm{Yb}$ and ${ }^{175} \mathrm{Lu}$ and using ${ }^{176} \mathrm{Yb} /{ }^{173} \mathrm{Yb}=0.79462$ and ${ }^{176} \mathrm{Lu} /{ }^{175} \mathrm{Lu}=0.02653 . \mathrm{Lu}-\mathrm{Hf}$ sample data were normalized using 
reference material 91500 relative to an expected ${ }^{176} \mathrm{Lu} /{ }^{177} \mathrm{Hf}$ of 0.000311 (Woodhead et al., 2004).

All uncertainties were propagated using quadratic addition to reflect the reproducibility of replicate measurements of the Mudtank reference material with the $\varepsilon \mathrm{Hf}$ and $\mathrm{T}_{\mathrm{DM}}$ uncertainties incorporating components to reflect the uncertainty on the determined ${ }^{176} \mathrm{Hf} /{ }^{177} \mathrm{Hf}$, ${ }^{176} \mathrm{Yb} /{ }^{177} \mathrm{Hf}$ and ${ }^{176} \mathrm{Lu} /{ }^{177} \mathrm{Hf}$ ratios as well as the uncertainty on the U-Pb age. The ${ }^{176} \mathrm{Lu}$ decay constant and chondrite and depleted mantle values of Blitchert-Toft and Albarede (1997) were used to calculate $\varepsilon \mathrm{Hf}$ and $\mathrm{T}_{\mathrm{DM}}$ model ages.

\section{$\underline{\text { References: }}$}

Blitchert-Toft, J.\& Albarede, F. (1997). The Lu-Hf isotope geochemistry of chondrites and the evolution of the mantle-crust system. Earth and Planetary Science Letters, 148, $243-258$.

Dodson, M.H., Compston, W., Williams, I.S. \& Wilson, J.F. (1988). A search for ancient detrital zircons in Zimbabwean sediments. Journal of the Geological Society London, 145, 977-983.

Horstwood, M.S.A., Foster, G.L., Parrish, R.R., Noble, S.R. \& Nowell, G.M. (2003). Common- $\mathrm{Pb}$ corrected in situ $\mathrm{U}-\mathrm{Pb}$ accessory mineral geochronology by LA-MC-ICPMS. Journal of Analytical Atomic Spectrometry, 18, 837-846.

Steiger, R.H. \& Jager, E. (1977). Subcommission on geochronology: convention on the use of decay constants in geo- and cosmochronology. Earth and Planetary Science Letters, 36, 359-362. 
Woodhead, J.D., Hergt, J., Shelley, M., Eggins, S. \& Kemp, R. (2004). Zircon Hf-isotope analysis with an excimer laser, depth profiling, ablation of complex geometries, and concomitant age estimation. Chemical Geology, 209, 121-135. 


\section{FIGURE CAPTIONS}

Fig. 1. [A] Map of the Canning Basin showing its sub-basins, detrital zircon sample locations, and place names mentioned in the text. [B] Map of Australia showing basement terranes discussed in the text and location of detrital zircon samples (CAP: Capparis-1, CYC: Cycas-1, DRO: Drosera-1). Geological map modified from Raymond et al. (2012). YIL: Yilgarn Craton, CAO: Capricorn Orogen. PIL: Pilbara Craton, RUD: Rudall Complex, PAO: Paterson Orogen, MUS: Musgrave Block, ARU: Arunta Inlier, GRT: Granites Tanami, HC-KL: Hall's Creek- King Leopold Orogen, KIM: Kimberley Basin, PCO: Pine Creek Orogen, TCI: Tennant Creek Inlier, MII: Mt Isa Inlier, NEO: New England Orogen, LFB: Lachlan Fold Belt, GAW: Gawler Craton.

Fig. 2. Photographs of Grant Group exposed in the Fitzroy River valley and Pilbara region and cores from Barbwire Terrace (BWT). [A] Glacially striated basement pavements exposed in the Oakover River area (UTM 298790E 7627510N) indicating ice flow towards $\sim$ NNW $(\mathrm{n}=76)$ into Canning Basin from Pilbara Craton. Overlying tillites dated as Early Permian (Backhouse, 1992). [B] Homogenous muddy siltstone at base of upper Grant facies associations at Grant Range, with out-sized exotic clast, deposited by rainout of debris from floating ice or glacial gravity flow within glaciomarine environment. [C] Massive, matrix-supported diamictite of lower facies association from BWT (Eremophila-3, 251.3 m), with faceted Devonian carbonate clasts and rounded, exotic granitic clasts, deposited from cohesive debris flows (sensu Mulder and Alexander, 2001). Similar diamictites were associated with CAP detrital zircon sample (Fig. 6). [D] Massive and thinly bedded turbidite sandstones of lower facies association of BWT (Melaleuca-1, $306.7 \mathrm{~m}$ ). Similar sandstones were sampled for detrital zircons from Drosera-1 (DRO; Fig. 6). [E] Thin interbeds of sandstone and muddy silt- 
stone of upper facies associations at Grant Range. Internal bedforms and sole structures in sandstone beds indicate deposition from turbidity currents, during regressive phase following maximum flooding in the basin. [F] Sub-vertical Skolithos burrows up to $0.5 \mathrm{~m}$ long within planar cross-bedded nearshore/beach sandstones of upper facies association in St. George Ranges. Note overlying, intensely bioturbated Macaronichnus segregatis bed. Such trace fossils in upper facies associations of the Grant Group form part of a low diversity assemblage reflecting the abundance of freshwater input into the Canning Basin upon deglaciation (cf. Buatois et al., 2006). [G] Large scale channel-belt complexes of lower facies associations exposed at Grant Range. Their vertical association with glaciomarine deposits suggests deposition within extensive proglacial outwash channel-belt complexes, demonstrating the large flux of meltwater and sand-grade sediment from retreating ice margins into the Fitzroy Trough. CYC detrital zircons were sampled from a similar channel sandstone. [H] Typical view of upper Grant Group exposures in Fitzroy Valley (in St. George Ranges), showing scree-covered mud- and siltstones recording maximum flooding, overlain by regressive channel sandstone complexes deposited in response to increased sediment supply during deglaciation.

Fig. 3. Canning Basin LPIA-related stratigraphy with relative position of detrital zircon samples. Two youngest Grant Group detrital zircon ages with maximum age error bars (2 sigma) shown. Stages following Gradstein et al. (2012), palynological zones modified from Apak and Backhouse (1998, 1999), Archbold (1999), Mory (2010), Taboada et al. (2015), Bodorokos et al. (2016) and Mory et al. (2017) with dashed lines recognising the current uncertainty in age range of Pennsylvanian to Sakmarian zones, Grant Group macrofaunal age from Archbold (1995) and Taboada et al. (2015), and eastern Australia glacial phases after Fielding et al. (2008; blue boxes) and Waterhouse \& Shi (2013; grey boxes). 
Fig. 4. Rose diagram of all Grant Group paleocurrents measured from Fitzroy Valley outcrops, demonstrating strongly offshore trend (towards NW). Measurements made from various structures including cross-bedding, ripple lamination, and intraformational striae.

Fig. 5. CL images illustrating internal textures of different zircon age groups discussed in text. Ablation target area circled for U-Pb (unlabeled) and $\mathrm{Hf}$ (labeled).

Fig. 6. Sedimentary logs of petroleum well cores sampled for this detrital zircon study (see Fig. 1 for location). Lithofacies code modified from Evans and Benn (2004).

Fig. 7. U-Pb Concordia diagrams for, $[\mathrm{A}]$ all detrital zircons, $[\mathrm{B}]$ detrital zircons with $\mathrm{U}-\mathrm{Pb}$ ages $<2000 \mathrm{Ma}$, and [C] detrital zircons with $\mathrm{U}-\mathrm{Pb}$ ages $<600 \mathrm{Ma}$. Plotted with Isoplot (Ludwig, 2003).

Fig. 8. Age probability distribution plot of $\mathrm{U}-\mathrm{Pb}$ ages for all analyses and for $\mathrm{U}-\mathrm{Pb}$ ages with $<10 \%$ discordance filter applied. Ages $<1000$ Ma based on ${ }^{206} \mathrm{~Pb}^{*} / 238 \mathrm{U}$ ratios and ages $>$ $1000 \mathrm{Ma}$ based on ${ }^{207} \mathrm{~Pb}^{*} /{ }^{206} \mathrm{~Pb}^{*}$ ratios. Applying a $10 \%$ discordance cut off biases the data to older ${ }^{207} \mathrm{~Pb} * /{ }^{206} \mathrm{~Pb} *$ ages relative to younger ${ }^{206} \mathrm{~Pb} * 2{ }^{238} \mathrm{U}$ ages, despite many young ages intercepting concordia (Fig. 6C). Plotted using Isoplot (Ludwig, 2003).

Fig. 9. Epsilon $\mathrm{Hf}(\varepsilon \mathrm{Hf})$ versus crystallization age plot, and $\mathrm{U}-\mathrm{Pb}$ age probability distribution plots for detrital zircon samples DRO, CAP and CYC. Ages $<1000$ Ma based on ${ }^{206} \mathrm{~Pb}^{* / 238} \mathrm{U}$ ratios and ages $>1000$ Ma based on ${ }^{207} \mathrm{~Pb}^{*} /{ }^{206} \mathrm{~Pb}^{*}$ ratios. A $10 \%$ shift for ages of 300 and 1500 Ma equates with a shift of c. 0.5 and 3 eHf values, respectively. Hf evolution curves 
marked for chondrites unfractionated reservoir (CHUR) and depleted mantle (DM). Probability distributions plotted using Isoplot (Ludwig, 2003).

Fig. 10. Weighted average ${ }^{206} \mathrm{~Pb}^{* / 238} \mathrm{U}$ age for two youngest Grant Group detrital zircons from sample CAP (cap44b and cap103a; Tables 3 and 4). Plotted using Isoplot (Ludwig, 2003).

Fig. 11. Epsilon Hf ( $(\mathrm{Hf})$ versus crystallization age plot for western and central Australian basement terranes, plotted against Canning Basin detrital zircon dataset (location map in Fig. 1 and basement references discussed in text). Note the similarity between Canning Basin Mesoproterozoic detrital zircons and Arunta and Musgrave terranes, and similarly for Neoproterozoic-Cambrian detrital zircons with those from the Yilgarn terrane.

Fig. 12. Schematic maps summarising erosional and depositional evidence for the LPIA regional glaciation model in western and central Australia. A) Mid-Carboniferous (c. Bashkirian) evidence for glaciation is limited to only sedimentological data for the glaciomarine Nangetty Formation in the Perth Basin. There is currently no direct evidence for the Reeves Formation in the Canning Basin having a glacial association. B) Evidence for extensive glaciation in the Early Permian (c. Asselian) is preserved in the stratigraphic record of all western and central Australian Phanerozoic basins (e.g. Mory et al., 2008) with information on icesheet dynamics provided by erosional phenomena and products, including: Grant Group detrital zircons (this study), sub-glacial striated pavements and valleys (this study; O'Brien et al., 1998; Eyles \& de Broekert, 2001; Gorter et.al., 2008; Mory, 2010; Haines et al., 2011; AlHinaai, 2014; Al-Hinaai \& Redfern, 2015), and intra-formational striae and Grant Group paleocurrents (this study; O'Brien \& Christie-Blick, 1992). 
Table 1. Heavy mineral count for detrital zircon samples with cored petroleum well/sample name (DRO: Drosera-1, CAP: Capparis-1, CYC: Cycas-1), depth of sample (m), number, N, of grains counted, and heavy mineral percentage of total (An: anatase, Ap: apatite, Bi: biotite, Cd: chloritoid, Ct: chlorite, Ep: epidote, Ga: garnet, Mo: monazite, Ru: rutile, Sp: sphene, To: tourmaline, Zr: zircon).

Table 2. All Grant Group detrital zircon U-Pb laser ablation MC-ICP-MS analyses.

Table 3. U-Pb laser ablation MC-ICP-MS analyses of two youngest detrital zircons from sample CAP.

Table 4. Hf-isotope laser ablation MC-ICP-MS analyses of two youngest detrital zircons from sample CAP.

Table 5. All Grant Group detrital zircon Hf-isotope laser ablation MC-ICP-MS analyses. 
Fig. 1. [A] Map of the Canning Basin showing its sub-basins, detrital zircon sample locations, and place names mentioned in the text. [B] Map of Australia showing basement terranes discussed in the text and location of detrital zircon samples (CAP: Capparis-1, CYC: Cycas-1, DRO: Drosera-1). Geological map modified from Raymond et al. (2012). YIL: Yilgarn Craton, CAO: Capricorn Orogen. PIL: Pilbara Craton, RUD: Rudall Complex, PAO: Paterson Orogen, MUS: Musgrave Block, ARU: Arunta Inlier, GRT: Granites Tanami, HC-KL: Hall's Creek- King Leopold Orogen, KIM: Kimberley Basin, PCO: Pine Creek Orogen, TCI: Tennant Creek Inlier, MII: Mt Isa Inlier, NEO: New England Orogen, LFB: Lachlan Fold Belt, GAW: Gawler Craton.

$151 \times 251 \mathrm{~mm}(300 \times 300 \mathrm{DPI})$ 

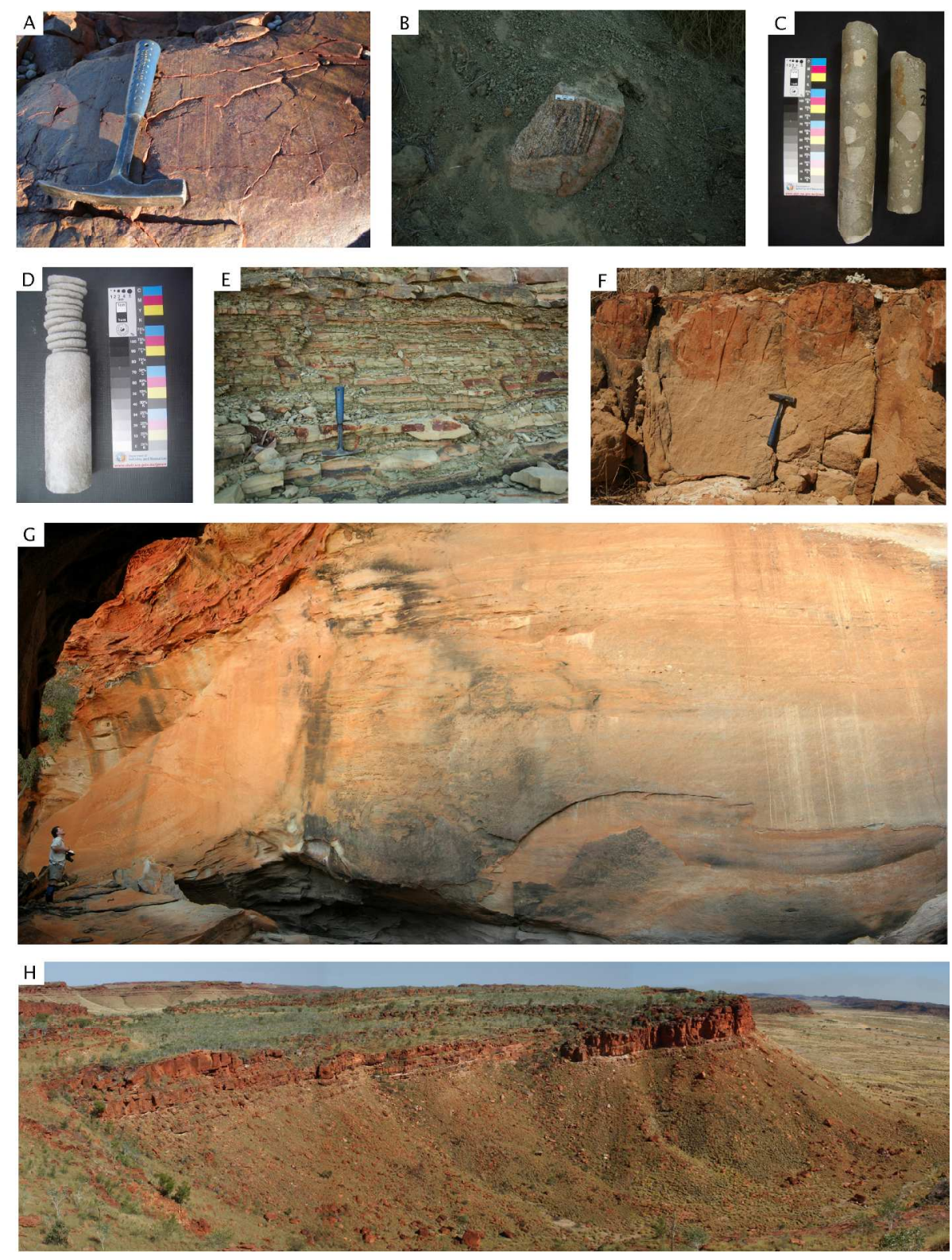

Fig. 2. Photographs of Grant Group exposed in the Fitzroy River valley and Pilbara region and cores from Barbwire Terrace (BWT). [A] Glacially striated basement pavements exposed in the Oakover River area (UTM 298790E 7627510N) indicating ice flow towards NNW $(n=76)$ into Canning Basin from Pilbara Craton. Overlying tillites dated as Early Permian (Backhouse, 1992). [B] Homogenous muddy siltstone at base of upper Grant facies associations at Grant Range, with out-sized exotic clast, deposited by rainout of debris from floating ice or glacial gravity flow within glaciomarine environment. [C] Massive, matrixsupported diamictite of lower facies association from BWT (Eremophila-3, 251.3 m), with faceted Devonian carbonate clasts and rounded, exotic granitic clasts, deposited from cohesive debris flows (sensu Mulder and Alexander, 2001). Similar diamictites were associated with CAP detrital zircon sample (Fig. 6). [D] Massive and thinly bedded turbidite sandstones of lower facies association of BWT (Melaleuca-1, 306.7 m). Similar sandstones were sampled for detrital zircons from Drosera-1 (DRO; Fig. 6). [E] Thin interbeds of sandstone and muddy siltstone of upper facies associations at Grant Range. Internal bedforms and sole structures in sandstone beds indicate deposition from turbidity currents, during regressive phase following maximum 
flooding in the basin. [F] Sub-vertical Skolithos burrows up to $0.5 \mathrm{~m}$ long within planar cross-bedded nearshore/beach sandstones of upper facies association in St. George Ranges. Note overlying, intensely bioturbated Macaronichnus segregatis bed. Such trace fossils in upper facies associations of the Grant Group form part of a low diversity assemblage reflecting the abundance of freshwater input into the Canning Basin upon deglaciation (cf. Buatois et al., 2006). [G] Large scale channel-belt complexes of lower facies associations exposed at Grant Range. Their vertical association with glaciomarine deposits suggests deposition within extensive proglacial outwash channel-belt complexes, demonstrating the large flux of meltwater and sand-grade sediment from retreating ice margins into the Fitzroy Trough. CYC detrital zircons were sampled from a similar channel sandstone. $[\mathrm{H}]$ Typical view of upper Grant Group exposures in Fitzroy Valley (in St. George Ranges), showing scree-covered mud- and siltstones recording maximum flooding, overlain by regressive channel sandstone complexes deposited in response to increased sediment supply during deglaciation.

$179 \times 237 \mathrm{~mm}(300 \times 300 \mathrm{DPI})$ 

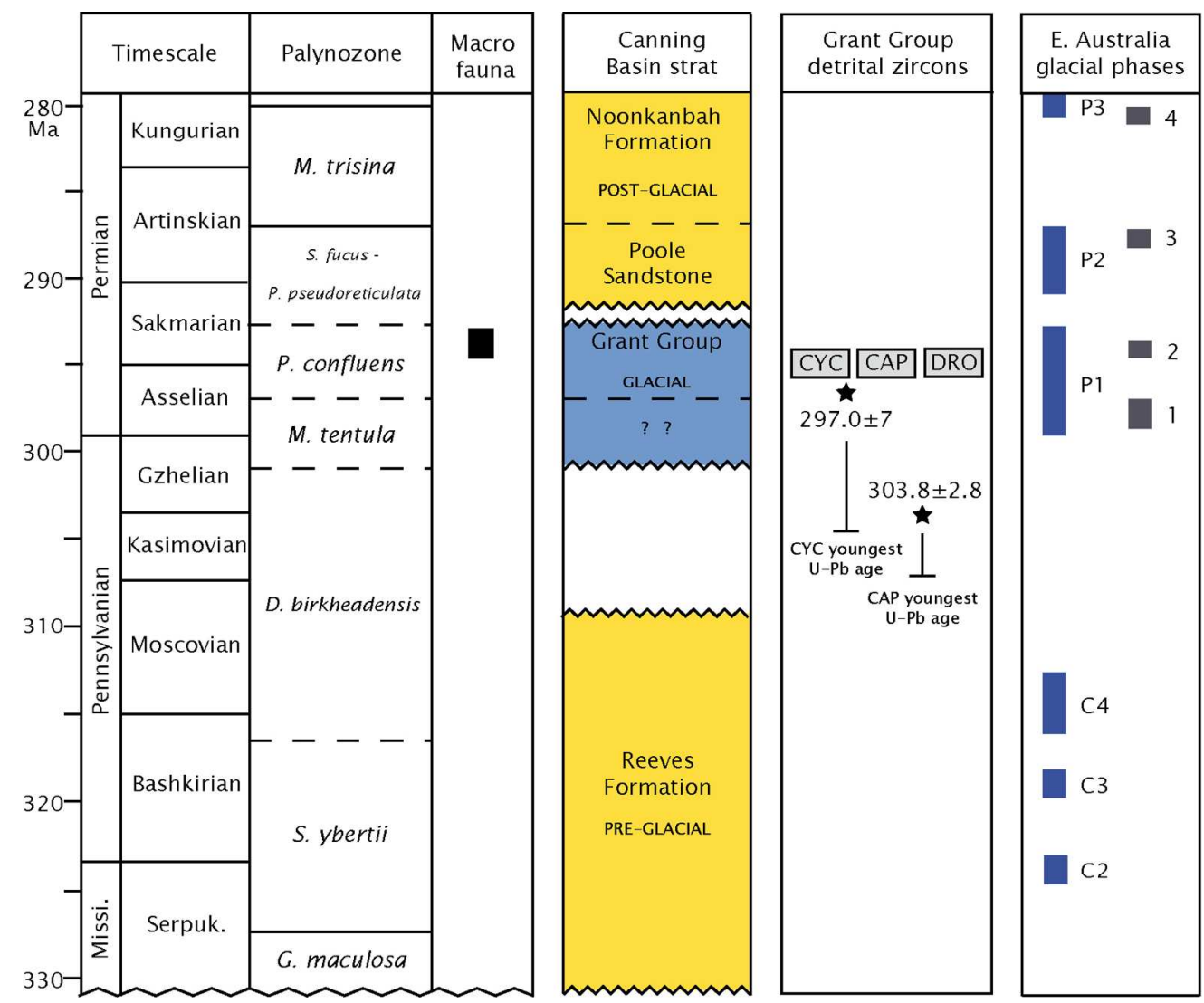

Fig. 3. Canning Basin LPIA-related stratigraphy with relative position of detrital zircon samples. Two youngest Grant Group detrital zircon ages with maximum age error bars ( 2 sigma) shown. Stages following Gradstein et al. (2012), palynological zones modified from Apak and Backhouse $(1998,1999)$, Archbold (1999), Mory (2010), Taboada et al. (2015), Bodorokos et al. (2016) and Mory et al. (2017) with dashed lines recognising the current uncertainty in age range of Pennsylvanian to Sakmarian zones, Grant Group macrofaunal age from Archbold (1995) and Taboada et al. (2015), and eastern Australia glacial phases after Fielding et al. (2008; blue boxes) and Waterhouse \& Shi (2013; grey boxes). 
Fig. 4. Rose diagram of all Grant Group paleocurrents measured from Fitzroy Valley outcrops, demonstrating strongly offshore trend (towards NW). Measurements made from various structures including cross-bedding, ripple lamination, and intraformational striae.

$113 \times 112 \mathrm{~mm}(300 \times 300 \mathrm{DPI})$ 

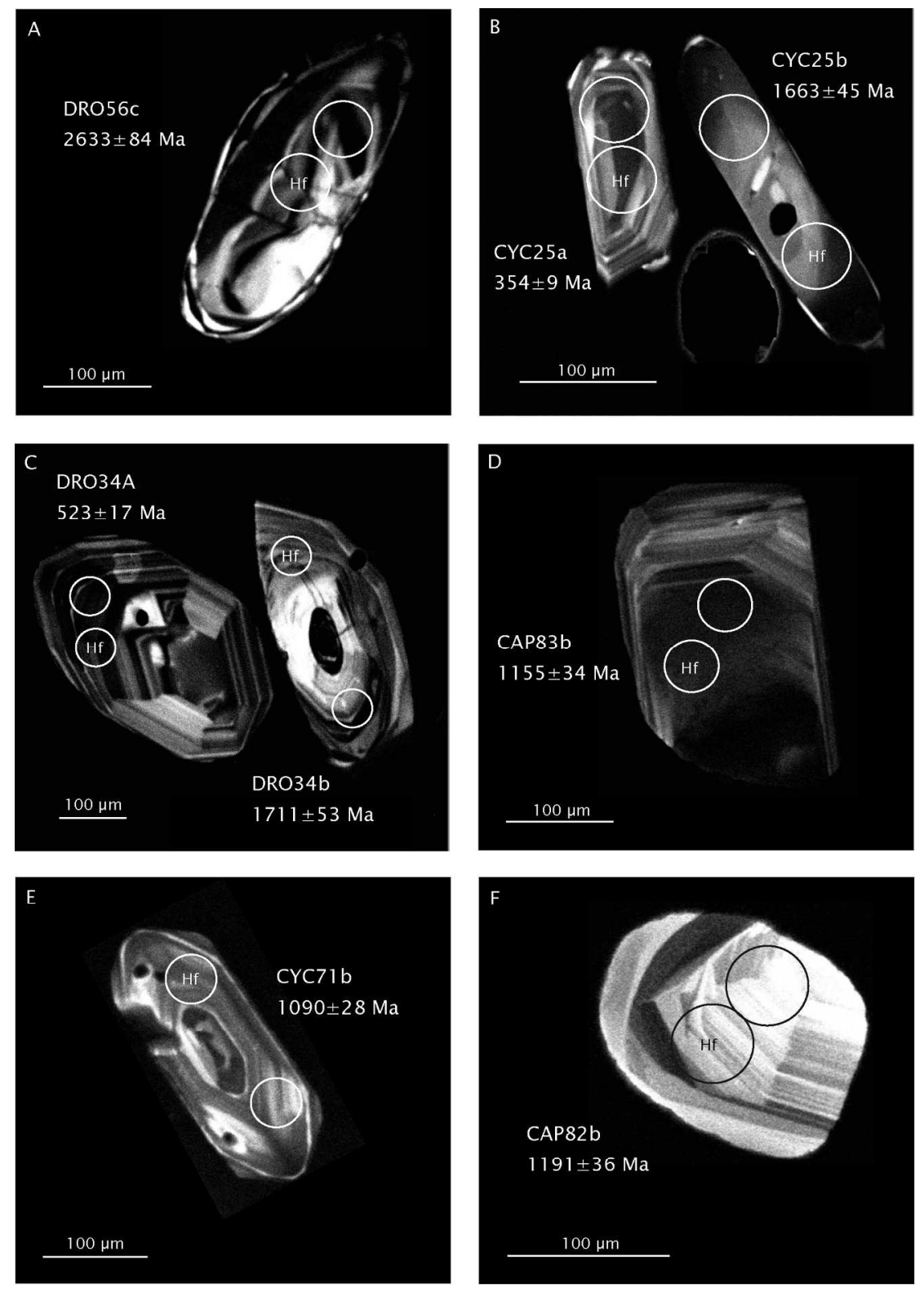

Fig. 5. CL images illustrating internal textures of different zircon age groups discussed in text. Ablation target area circled for $\mathrm{U}-\mathrm{Pb}$ (unlabeled) and $\mathrm{Hf}$ (labeled).

$162 \times 230 \mathrm{~mm}(300 \times 300 \mathrm{DPI})$ 

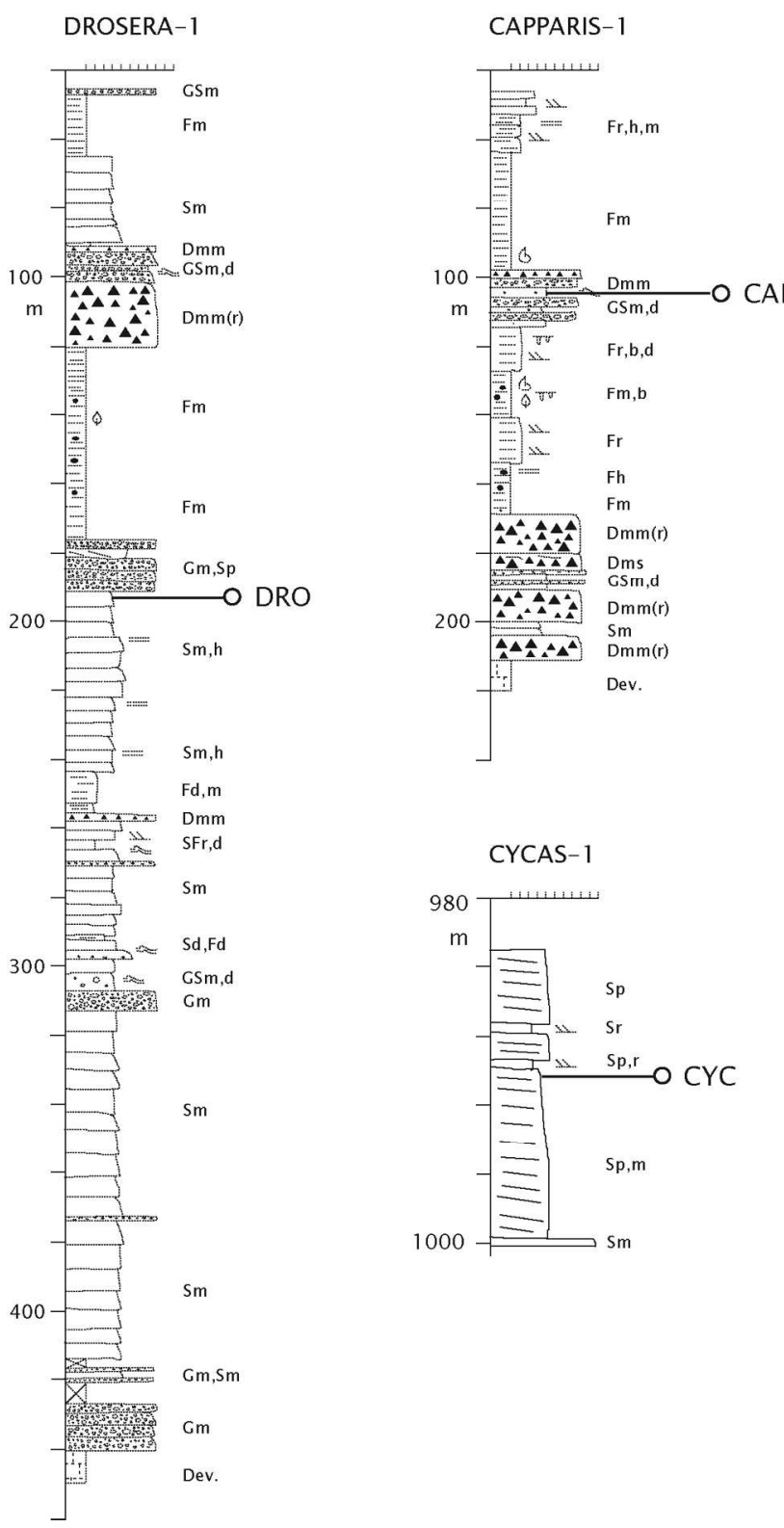

CYCAS-1

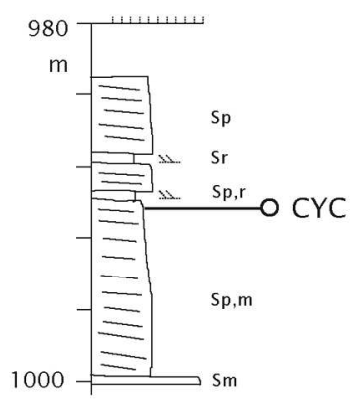

Fig. 6. Sedimentary logs of petroleum well cores sampled for this detrital zircon study (see Fig. 1 for location). Lithofacies code modified from Evans and Benn (2004).

$104 \times 198 \mathrm{~mm}(300 \times 300 \mathrm{DPI})$ 

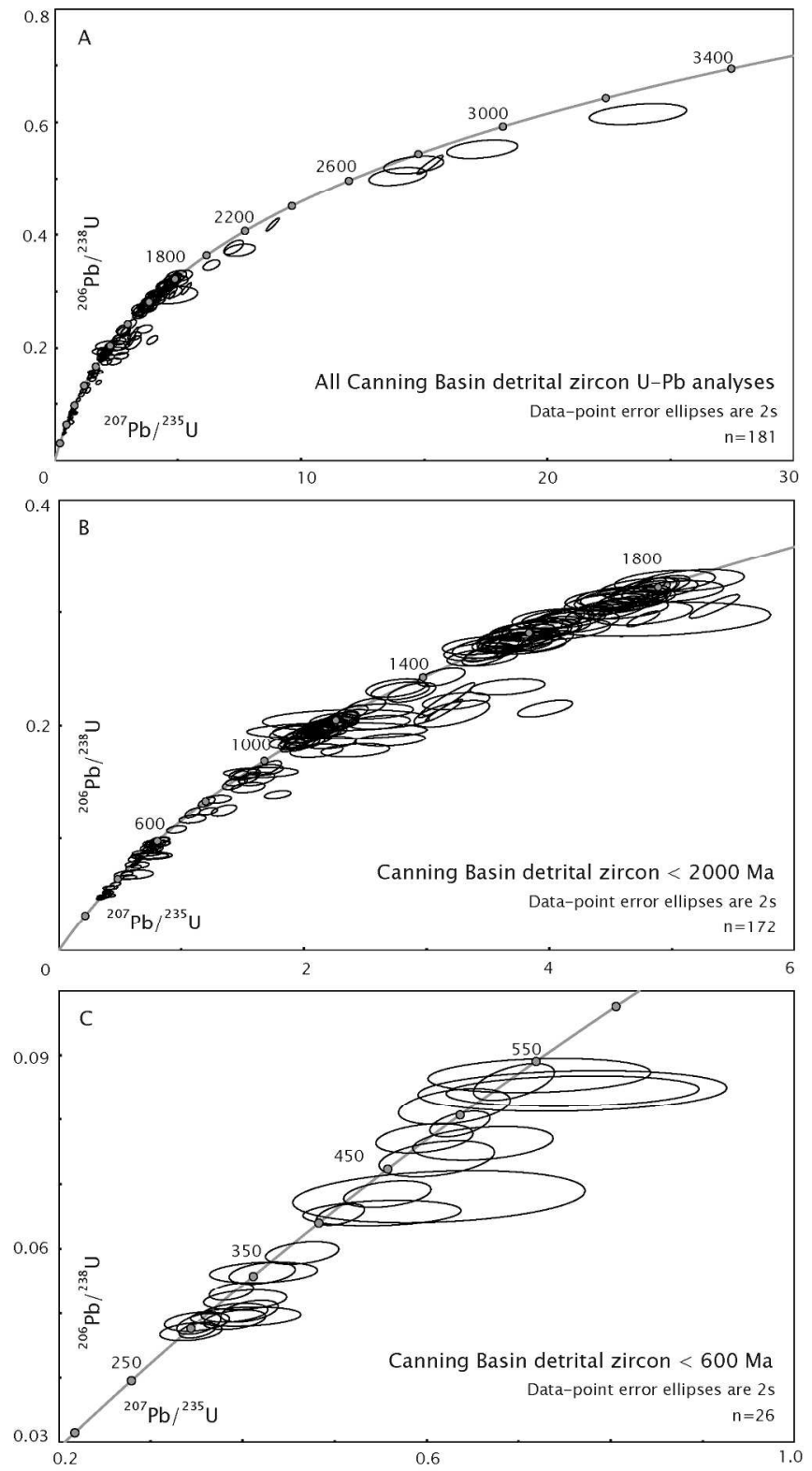

Fig. 7. U-Pb Concordia diagrams for, $[\mathrm{A}]$ all detrital zircons, $[\mathrm{B}]$ detrital zircons with $\mathrm{U}-\mathrm{Pb}$ ages $<2000 \mathrm{Ma}$, and [C] detrital zircons with U-Pb ages < $600 \mathrm{Ma}$. Plotted with Isoplot (Ludwig, 2003).

$137 \times 254 \mathrm{~mm}(300 \times 300 \mathrm{DPI})$ 
Fig. 8. Age probability distribution plot of $\mathrm{U}-\mathrm{Pb}$ ages for all analyses and for $\mathrm{U}-\mathrm{Pb}$ ages with $<10 \%$ discordance filter applied. Ages $<1000 \mathrm{Ma}$ based on ${ }^{206} \mathrm{~Pb} * /{ }^{238} \mathrm{U}$ ratios and ages $>1000 \mathrm{Ma}$ based on ${ }^{207} \mathrm{~Pb} * /{ }^{206} \mathrm{~Pb} *$ ratios. Applying a $10 \%$ discordance cut off biases the data to older ${ }^{207} \mathrm{~Pb}^{*} /{ }^{206} \mathrm{~Pb} *$ ages relative to younger ${ }^{206} \mathrm{~Pb}^{*} /{ }^{238} \mathrm{U}$ ages, despite many young ages intercepting concordia (Fig. 6C). Plotted using Isoplot (Ludwig, 2003).

$197 \times 123 \mathrm{~mm}(300 \times 300 \mathrm{DPI})$ 


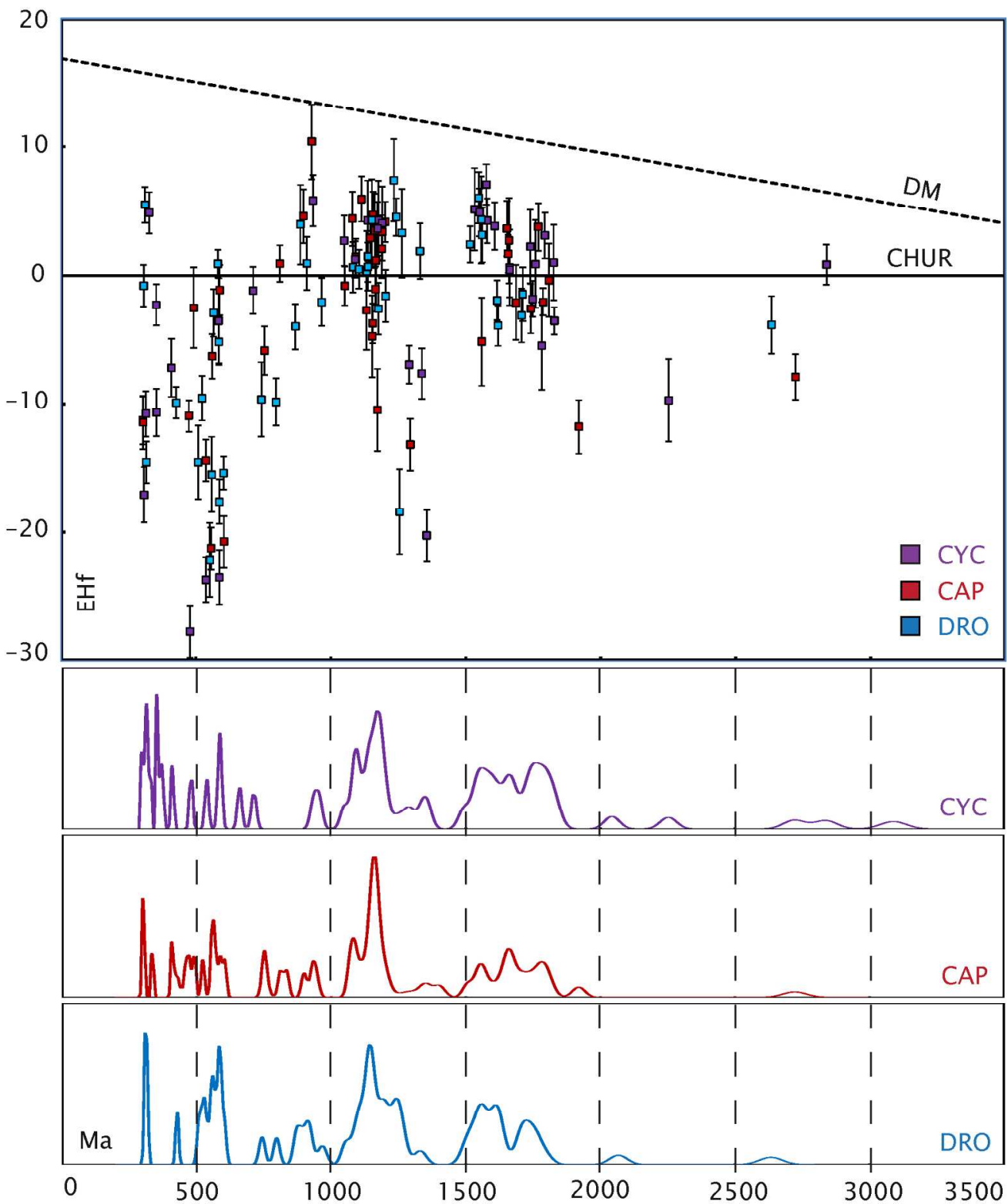

Fig. 9. Epsilon $\mathrm{Hf}(\varepsilon \mathrm{Hf})$ versus crystallization age plot, and $\mathrm{U}-\mathrm{Pb}$ age probability distribution plots for detrital zircon samples DRO, CAP and CYC. Ages < $1000 \mathrm{Ma}$ based on ${ }^{206} \mathrm{~Pb}^{*} /{ }^{238} \mathrm{U} *$ ratios and ages $>1000 \mathrm{Ma}$ based on ${ }^{207} \mathrm{~Pb} * /{ }^{206} \mathrm{~Pb} *$ ratios. A $10 \%$ shift for ages of 300 and $1500 \mathrm{Ma}$ equates with a shift of c. 0.5 and $3 \mathrm{\varepsilon Hf}$ values, respectively. Hf evolution curves marked for chondrites unfractionated reservoir (CHUR) and depleted mantle (DM). Probability distributions plotted using Isoplot (Ludwig, 2003).

$176 \times 212 \mathrm{~mm}(300 \times 300 \mathrm{DPI})$ 


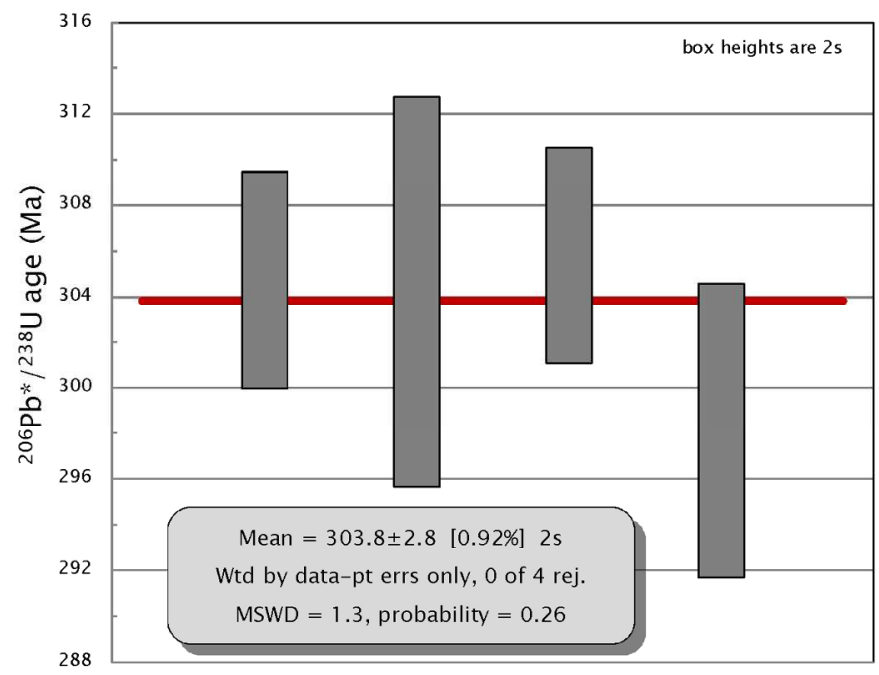

Fig. 10. Weighted average ${ }^{206} \mathrm{~Pb}^{*} /{ }^{238} \mathrm{U} *$ age for two youngest Grant Group detrital zircons from sample CAP (cap44b and cap103a; Tables 3 and 4). Plotted using Isoplot (Ludwig, 2003).

$166 \times 108 \mathrm{~mm}(300 \times 300 \mathrm{DPI})$ 


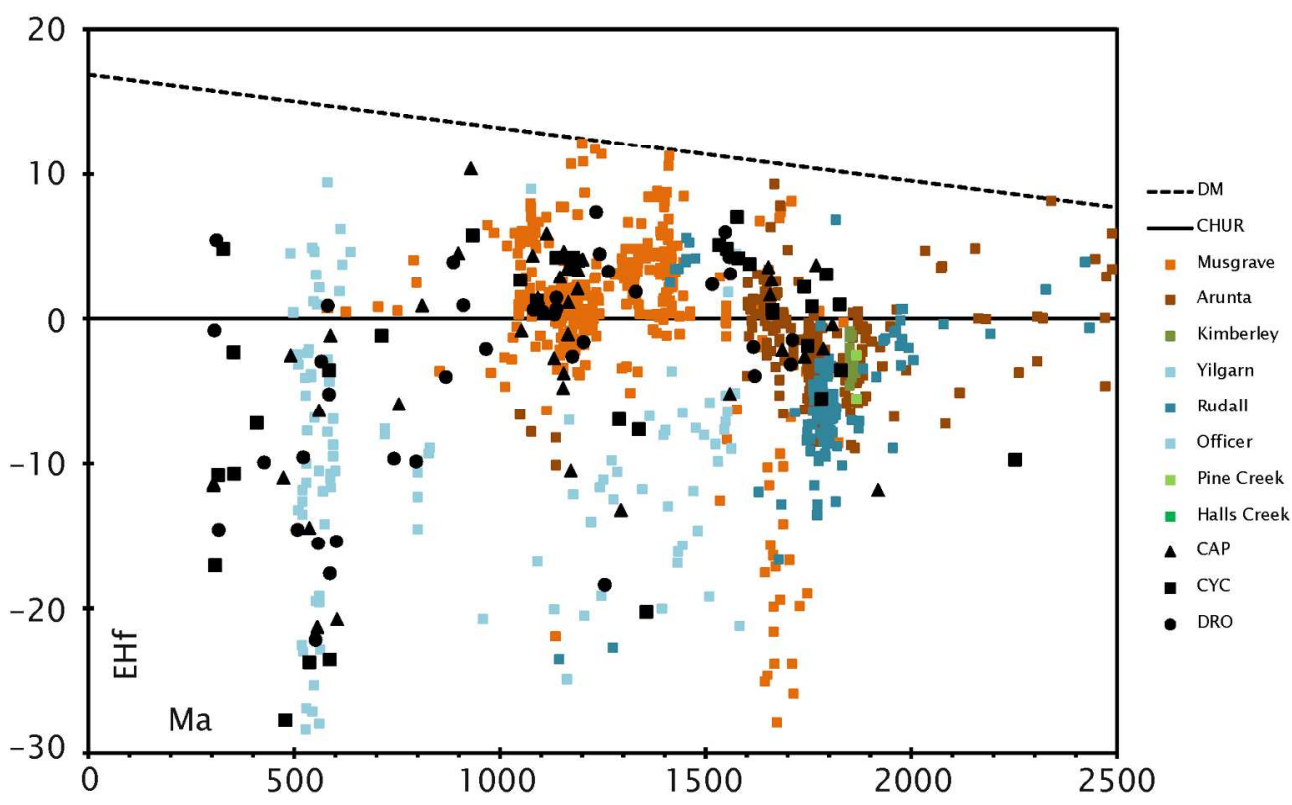

Fig. 11. Epsilon $\mathrm{Hf}(\varepsilon \mathrm{Hf})$ versus crystallization age plot for western and central Australian basement terranes, plotted against Canning Basin detrital zircon dataset (location map in Fig. 1 and basement references discussed in text). Note the similarity between Canning Basin Mesoproterozoic detrital zircons and Arunta and Musgrave terranes, and similarly for Neoproterozoic - Cambrian detrital zircons with those from the Yilgarn terrane.

$173 \times 105 \mathrm{~mm}(300 \times 300 \mathrm{DPI})$ 

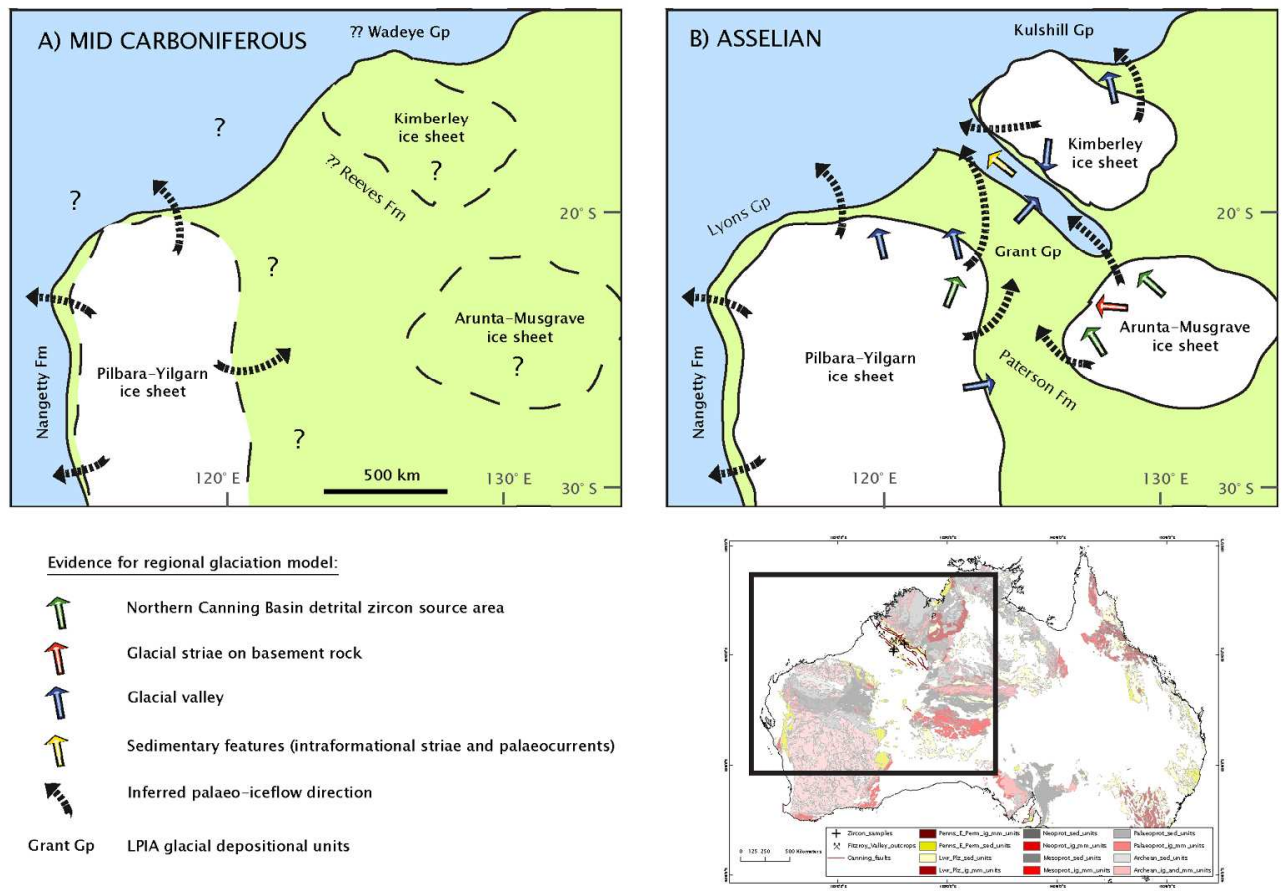

Fig. 12. Schematic maps summarising erosional and depositional evidence for the LPIA regional glaciation model in western and central Australia. A) Mid-Carboniferous (c. Bashkirian) evidence for glaciation is limited to only sedimentological data for the glaciomarine Nangetty Formation in the Perth Basin. There is currently no direct evidence for the Reeves Formation in the Canning Basin having a glacial association. B) Evidence for extensive glaciation in the Early Permian (c. Asselian) is preserved in the stratigraphic record of all western and central Australian Phanerozoic basins (e.g. Mory et al., 2008) with information on ice-sheet dynamics provided by erosional phenomena and products, including: Grant Group detrital zircons (this study), sub-glacial striated pavements and valleys (this study; O'Brien et al., 1998; Eyles \& de Broekert, 2001; Gorter et.al., 2008; Mory, 2010; Haines et al., 2011; Al-Hinaai, 2014; Al-Hinaai \& Redfern, 2015), and intra-formational striae and Grant Group paleocurrents (this study; O'Brien \& Christie-Blick, 1992).

$179 \times 123 \mathrm{~mm}(300 \times 300 \mathrm{DPI})$ 


$\begin{array}{ccccccc}\text { Sample } & \text { Depth } & \mathbf{N} & \mathbf{\% A n} & \mathbf{\% A p} & \mathbf{\% B i} & \mathbf{\% C d} \\ \text { DRO } & 990.6 & 500 & 1 & 5 & 0 & 0 \\ \text { CAP } & 106.9 & 500 & 0 & 4 & 1 & 0 \\ \text { CYC } & 990.6 & 500 & 4 & 4 & 0 & <1\end{array}$




$\begin{array}{cc}\% \mathbf{C t} & \text { \%Ep } \\ 0 & <1 \\ <1 & 0 \\ 0 & 2\end{array}$

$\begin{array}{ccc}\% \text { Ga } & \text { \%Mo } & \text { \%Ru } \\ 65 & 0 & 2 \\ 68 & <1 & 2 \\ 25 & <1 & 8\end{array}$

$\%$ Sp
$<1$
0
3

\% To
11
12
7


1

2

3

4

5

6

7

8

9

10

11

12

13

14

15

16

17

18

19

20

21

22

24

25

26

27

28

29

30

31

32

33

34

35

36

37

38

39

40

41

42

43

44

45

46

47

48

49

50

51

52

53

54

55

56

57

58

59

60
$\% \mathrm{Zr}$

15

13

47 
Table 2 - All LA U-Pb MC-ICP-MS data

\begin{tabular}{|c|c|c|c|c|c|c|c|c|c|c|c|c|c|c|c|c|c|c|c|c|c|}
\hline & & & Signals & & & & & & & Ratios & & & & & & Ages (Ma) & & & & & \\
\hline Sample & ${ }^{204} \mathrm{~Pb}$ & ${ }^{206} \mathrm{~Pb}^{*}$ & ${ }^{207} \mathrm{~Pb}^{*}$ & ${ }^{238} \mathrm{U}$ & f206\% & Uppm*t & $\overline{{ }^{207} \mathrm{~Pb}^{*} / /^{206} \mathrm{~Pb}^{*}}$ & $10 \%$ & ${ }^{206} \mathrm{~Pb}^{*} \mathrm{l}^{238} \mathrm{U}$ & $10 \%$ & 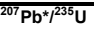 & $10 \%$ & Rho & ${ }^{207} \mathrm{~Pb} / /^{206} \mathrm{~Pb}$ & $2 \sigma$ abs & ${ }^{206} \mathrm{~Pb}^{* / 238} \mathrm{U}$ & $2 \sigma$ abs & 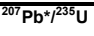 & $2 \sigma$ abs & $\%$ disc & Cm-Pb corr'd? \\
\hline cap gr1-1 & 0.001 & 32.5 & 3.54 & 73 & 0.1 & 206 & 0.1087 & 1.3 & 0.3195 & 1.0 & 4.790 & 1.7 & 0.62 & 1778 & 48 & 1787 & 43 & 1783 & 152 & -0.5 & $\mathrm{~N}$ \\
\hline cap gr2-1 & 0.003 & 6.1 & 0.37 & 82 & 0.9 & 234 & 0.0527 & 2.3 & 0.0534 & 1.0 & 0.388 & 2.5 & 0.41 & 317 & 105 & 335 & 7 & 333 & 20 & -5.7 & $\mathrm{~N}$ \\
\hline cap 4a-1 & 0.001 & 24.3 & 1.86 & 98 & 0.1 & 279 & 0.0761 & 1.4 & 0.1801 & 1.0 & 1.889 & 1.7 & 0.60 & 1097 & 54 & 1067 & 24 & 1077 & 63 & 2.7 & $\mathrm{~N}$ \\
\hline сар4b-1 & 0.012 & 5.8 & 0.83 & 24 & 3.4 & 69 & 0.0760 & 7.5 & 0.1575 & 1.1 & 1.650 & 7.5 & 0.15 & 1094 & 299 & 943 & 23 & 990 & 226 & 13.8 & Y \\
\hline сар4c-1 & 0.000 & 25.9 & 2.81 & 63 & 0.0 & 179 & 0.1071 & 1.3 & 0.3047 & 1.1 & 4.499 & 1.7 & 0.62 & 1750 & 49 & 1714 & 41 & 1731 & 145 & 2.1 & $\mathrm{~N}$ \\
\hline сар5-1 & 0.000 & 29.8 & 2.53 & 112 & 0.0 & 318 & 0.0794 & 1.4 & 0.1994 & 1.0 & 2.184 & 1.7 & 0.61 & 1183 & 53 & 1172 & 27 & 1176 & 73 & 0.9 & $\mathrm{~N}$ \\
\hline cap6-1 & 0.001 & 12.8 & 0.94 & 64 & 0.1 & 180 & 0.0690 & 1.5 & 0.1551 & 1.0 & 1.475 & 1.8 & 0.57 & 898 & 60 & 929 & 20 & 920 & 52 & -3.4 & $\mathrm{~N}$ \\
\hline cap7a-1 & 0.000 & 9.5 & 1.20 & 23 & 0.0 & 65 & 0.1102 & 1.6 & 0.3237 & 1.1 & 4.918 & 1.9 & 0.57 & 1802 & 57 & 1808 & 45 & 1805 & 175 & -0.3 & $\mathrm{~N}$ \\
\hline cap7b-1 & 0.010 & 28.5 & 3.27 & 75 & 0.6 & 213 & 0.1049 & 1.4 & 0.2990 & 1.2 & 4.326 & 1.8 & 0.63 & 1713 & 53 & 1686 & 45 & 1698 & 150 & 1.6 & $Y$ \\
\hline сар8c-1 & -0.003 & 8.9 & 0.65 & 107 & -0.6 & 303 & 0.0562 & 1.8 & 0.0653 & 1.0 & 0.506 & 2.1 & 0.49 & 461 & 82 & 408 & 9 & 416 & 22 & 11.5 & $\mathrm{~N}$ \\
\hline cap9-1 & -0.001 & 7.9 & 0.63 & 77 & -0.1 & 218 & 0.0582 & 1.8 & 0.0793 & 1.0 & 0.636 & 2.1 & 0.49 & 538 & 80 & 492 & 10 & 500 & 27 & 8.5 & $\mathrm{~N}$ \\
\hline cap11c-1 & 0.000 & 3.6 & 0.43 & 14 & -0.2 & 40 & 0.0789 & 2.5 & 0.1959 & 1.1 & 2.130 & 2.7 & 0.39 & 1169 & 98 & 1153 & 27 & 1159 & 110 & 1.3 & $\mathrm{~N}$ \\
\hline cap12-1 & -0.001 & 2.1 & 0.18 & 9 & -0.8 & 26 & 0.0770 & 3.4 & 0.1920 & 1.0 & 2.038 & 3.6 & 0.29 & 1121 & 137 & 1132 & 26 & 1128 & 138 & -1.0 & $\mathrm{~N}$ \\
\hline cap-15 & -0.001 & 1.0 & 0.09 & 9 & -1.9 & 27 & 0.0652 & 7.3 & 0.0844 & 1.2 & 0.759 & 7.4 & 0.16 & 780 & 307 & 523 & 13 & 573 & 108 & 33.0 & $\mathrm{~N}$ \\
\hline сар16a-1 & 0.000 & 11.7 & 1.37 & 35 & 0.1 & 99 & 0.0954 & 1.4 & 0.2632 & 1.1 & 3.464 & 1.8 & 0.60 & 1537 & 55 & 1506 & 37 & 1519 & 120 & 2.0 & $\mathrm{~N}$ \\
\hline cap16b-1 & 0.007 & 73.3 & 8.65 & 203 & 0.2 & 575 & 0.1175 & 0.7 & 0.2941 & 1.0 & 4.765 & 1.2 & 0.82 & 1919 & 24 & 1662 & 36 & 1779 & 106 & 13.4 & $Y$ \\
\hline сар23-1 & 0.001 & 8.0 & 0.70 & 32 & 0.1 & 91 & 0.0816 & 1.7 & 0.1983 & 1.0 & 2.233 & 2.0 & 0.51 & 1237 & 69 & 1166 & 26 & 1191 & 88 & 5.7 & $\mathrm{~N}$ \\
\hline сар24-1 & 0.004 & 12.1 & 0.93 & 51 & 0.6 & 144 & 0.0793 & 1.4 & 0.1950 & 1.0 & 2.132 & 1.7 & 0.59 & 1180 & 55 & 1148 & 26 & 1159 & 73 & 2.7 & $\mathrm{~N}$ \\
\hline сар28-1 & 0.004 & 26.1 & 2.07 & 96 & 0.3 & 314 & 0.0794 & 1.9 & 0.1977 & 1.0 & 2.164 & 2.2 & 0.47 & 1182 & 76 & 1163 & 26 & 1170 & 92 & 1.7 & $\mathrm{~N}$ \\
\hline сар30a-1 & 0.019 & 29.5 & 6.10 & 67 & 1.0 & 219 & 0.1192 & 8.0 & 0.2938 & 2.1 & 4.829 & 8.3 & 0.25 & 1945 & 286 & 1660 & 79 & 1790 & 596 & 14.6 & Y \\
\hline сар35-1 & 0.003 & 12.7 & 1.27 & 36 & 0.4 & 119 & 0.1000 & 1.9 & 0.2736 & 1.3 & 3.771 & 2.3 & 0.56 & 1623 & 72 & 1559 & 46 & 1587 & 165 & 3.9 & $\mathrm{~N}$ \\
\hline сар37a-1 & -0.003 & 2.7 & 0.27 & 10 & -1.8 & 34 & 0.0809 & 3.3 & 0.1945 & 1.1 & 2.169 & 3.4 & 0.31 & 1218 & 128 & 1146 & 27 & 1171 & 141 & 6.0 & $\mathrm{~N}$ \\
\hline сар37b-1 & 0.001 & 4.6 & 0.37 & 28 & 0.3 & 92 & 0.0788 & 2.7 & 0.1242 & 1.6 & 1.349 & 3.1 & 0.52 & 1166 & 106 & 755 & 26 & 867 & 82 & 35.3 & $\mathrm{~N}$ \\
\hline сар 37c-1 & 0.018 & 16.1 & 1.67 & 42 & 1.8 & 139 & 0.0982 & 2.2 & 0.2850 & 1.5 & 3.859 & 2.7 & 0.55 & 1591 & 83 & 1616 & 54 & 1605 & 189 & -1.6 & $Y$ \\
\hline сар38-1 & -0.003 & 35.5 & 3.49 & 103 & -0.2 & 337 & 0.0962 & 1.9 & 0.2718 & 1.0 & 3.606 & 2.2 & 0.47 & 1552 & 71 & 1550 & 36 & 1551 & 147 & 0.1 & $\mathrm{~N}$ \\
\hline cap40a-1 & 0.002 & 6.4 & 0.47 & 55 & 0.5 & 181 & 0.0589 & 2.5 & 0.0901 & 1.1 & 0.731 & 2.7 & 0.39 & 563 & 109 & 556 & 12 & 557 & 39 & 1.2 & $\mathrm{~N}$ \\
\hline cap40b-1 & 0.023 & 59.3 & 6.13 & 220 & 0.6 & 719 & 0.1032 & 0.9 & 0.2224 & 2.8 & 3.163 & 3.0 & 0.95 & 1682 & 34 & 1294 & 80 & 1448 & 175 & 23.0 & $Y$ \\
\hline сар40c-1 & 0.015 & 16.1 & 1.02 & 173 & 1.6 & 567 & 0.0600 & 3.9 & 0.0739 & 1.5 & 0.611 & 4.2 & 0.36 & 603 & 169 & 460 & 14 & 484 & 51 & 23.7 & $Y$ \\
\hline сар41-1 & -0.001 & 56.6 & 5.77 & 154 & 0.0 & 505 & 0.1006 & 1.9 & 0.2922 & 1.0 & 4.054 & 2.2 & 0.47 & 1635 & 71 & 1653 & 38 & 1645 & 163 & -1.1 & $\mathrm{~N}$ \\
\hline сар44a-1 & -0.001 & 11.3 & 0.91 & 49 & -0.2 & 162 & 0.0768 & 2.0 & 0.1836 & 1.1 & 1.944 & 2.2 & 0.47 & 1115 & 79 & 1087 & 25 & 1096 & 85 & 2.5 & $\mathrm{~N}$ \\
\hline cap44b-1 & -0.001 & 10.4 & 0.57 & 177 & -0.2 & 578 & 0.0538 & 2.1 & 0.0473 & 1.1 & 0.351 & 2.3 & 0.45 & 363 & 94 & 298 & 6 & 306 & 17 & 17.8 & $\mathrm{~N}$ \\
\hline сар $44 \mathrm{e}-1$ & -0.004 & 27.3 & 3.04 & 71 & -0.2 & 231 & 0.1084 & 1.9 & 0.3100 & 1.0 & 4.634 & 2.2 & 0.47 & 1773 & 70 & 1741 & 40 & 1755 & 185 & 1.8 & $\mathrm{~N}$ \\
\hline cap44f-1 & 0.001 & 4.6 & 0.37 & 19 & 0.3 & 61 & 0.0803 & 2.3 & 0.1982 & 1.0 & 2.195 & 2.5 & 0.42 & 1205 & 89 & 1165 & 27 & 1179 & 105 & 3.3 & $\mathrm{~N}$ \\
\hline cap44h-1 & 0.000 & 57.4 & 7.69 & 134 & 0.0 & 438 & 0.1332 & 1.9 & 0.3467 & 1.1 & 6.367 & 2.2 & 0.49 & 2140 & 66 & 1919 & 47 & 2028 & 248 & 10.3 & $\mathrm{~N}$ \\
\hline cap46b-1 & 0.281 & 6.7 & 0.38 & 77 & 42.7 & 251 & 0.0654 & 10.3 & 0.0681 & 2.4 & 0.613 & 10.6 & 0.23 & 786 & 433 & 425 & 21 & 486 & 124 & 46.0 & $Y$ \\
\hline сар 48c-1 & -0.002 & 8.3 & 0.69 & 34 & -0.5 & 112 & 0.0786 & 2.1 & 0.1964 & 1.0 & 2.127 & 2.3 & 0.44 & 1161 & 84 & 1156 & 26 & 1158 & 97 & 0.4 & $\mathrm{~N}$ \\
\hline cap49_1 & 0.002 & 15.8 & 1.18 & 133 & 0.2 & 436 & 0.0602 & 2.0 & 0.0955 & 1.0 & 0.792 & 2.2 & 0.46 & 609 & 85 & 588 & 13 & 592 & 35 & 3.5 & $\mathrm{~N}$ \\
\hline сар59a-1 & 0.005 & 57.8 & 12.29 & 91 & 0.1 & 297 & 0.2103 & 0.5 & 0.5253 & 1.3 & 15.233 & 1.4 & 0.93 & 2908 & 17 & 2722 & 88 & 2830 & 363 & 6.4 & $Y$ \\
\hline cap59b-1 & 0.004 & 24.8 & 2.80 & 64 & 0.3 & 211 & 0.1088 & 1.9 & 0.3157 & 1.0 & 4.736 & 2.2 & 0.48 & 1780 & 70 & 1768 & 42 & 1774 & 191 & 0.6 & $\mathrm{~N}$ \\
\hline cap60b-1 & 0.003 & 4.7 & 0.40 & 28 & 1.1 & 92 & 0.0938 & 2.2 & 0.1381 & 1.0 & 1.786 & 2.5 & 0.42 & 1505 & 85 & 834 & 18 & 1040 & 86 & 44.6 & $\mathrm{~N}$ \\
\hline cap60c-1 & 0.001 & 5.7 & 0.42 & 26 & 0.4 & 86 & 0.0757 & 2.2 & 0.1823 & 1.1 & 1.902 & 2.4 & 0.43 & 1086 & 88 & 1080 & 25 & 1082 & 90 & 0.6 & $\mathrm{~N}$ \\
\hline сар61a-1 & -0.004 & 7.1 & 0.58 & 47 & -1.1 & 153 & 0.0718 & 2.3 & 0.1234 & 1.0 & 1.221 & 2.5 & 0.42 & 979 & 92 & 750 & 17 & 810 & 60 & 23.4 & $\mathrm{~N}$ \\
\hline cap61c-1 & 0.006 & 20.7 & 2.23 & 63 & 0.5 & 206 & 0.1050 & 1.8 & 0.2745 & 1.4 & 3.975 & 2.3 & 0.60 & 1715 & 67 & 1564 & 48 & 1629 & 169 & 8.8 & Y \\
\hline сар64c-1 & -0.002 & 5.5 & 0.50 & 29 & -0.7 & 96 & 0.0704 & 2.3 & 0.1496 & 1.0 & 1.452 & 2.5 & 0.41 & 940 & 94 & 899 & 20 & 911 & 71 & 4.4 & $\mathrm{~N}$ \\
\hline сар65a-1 & 0.003 & 8.0 & 0.78 & 69 & 0.6 & 226 & 0.0588 & 2.2 & 0.0908 & 1.0 & 0.736 & 2.5 & 0.42 & 559 & 97 & 561 & 12 & 560 & 36 & -0.2 & $\mathrm{~N}$ \\
\hline cap67d-1 & 0.002 & 5.5 & 0.33 & 46 & 0.7 & 151 & 0.0627 & 2.5 & 0.0982 & 1.1 & 0.850 & 2.7 & 0.38 & 699 & 108 & 604 & 13 & 624 & 46 & 13.6 & $\mathrm{~N}$ \\
\hline сар68b-1 & 0.003 & 9.0 & 0.62 & 81 & 0.6 & 266 & 0.0625 & 2.4 & 0.0926 & 1.1 & 0.799 & 2.6 & 0.44 & 692 & 101 & 571 & 14 & 596 & 42 & 17.5 & $\mathrm{~N}$ \\
\hline сар69a-1 & -0.001 & 5.9 & 0.55 & 25 & -0.3 & 83 & 0.0764 & 2.2 & 0.1886 & 1.0 & 1.985 & 2.5 & 0.42 & 1104 & 90 & 1114 & 25 & 1110 & 95 & -0.8 & $\mathrm{~N}$ \\
\hline cap70b-1 & 0.005 & 3.1 & 0.25 & 19 & 3.0 & 61 & 0.0699 & 3.5 & 0.1340 & 1.1 & 1.292 & 3.7 & 0.29 & 926 & 144 & 811 & 18 & 842 & 92 & 12.4 & $\mathrm{~N}$ \\
\hline сар72-1 & 0.003 & 4.3 & 0.48 & 14 & 1.0 & 39 & 0.0790 & 2.9 & 0.1847 & 1.4 & 2.012 & 3.3 & 0.43 & 1172 & 116 & 1093 & 33 & 1120 & 125 & 6.8 & $\mathrm{~N}$ \\
\hline сар $73 c-1$ & 0.007 & 2.9 & 0.38 & 8 & 3.6 & 24 & 0.0830 & 11.7 & 0.2047 & 1.8 & 2.343 & 11.9 & 0.15 & 1270 & 458 & 1201 & 48 & 1226 & 449 & 5.4 & $Y$ \\
\hline cap $75 b-1$ & 0.004 & 13.2 & 1.55 & 25 & 0.5 & 71 & 0.1083 & 1.9 & 0.3193 & 1.4 & 4.769 & 2.3 & 0.60 & 1771 & 68 & 1786 & 57 & 1779 & 203 & -0.8 & $\mathrm{~N}$ \\
\hline cap84a-1 & 0.001 & 25.4 & 2.76 & 55 & 0.1 & 156 & 0.1005 & 1.8 & 0.2931 & 1.4 & 4.061 & 2.3 & 0.60 & 1633 & 68 & 1657 & 52 & 1646 & 173 & -1.4 & $\mathrm{~N}$ \\
\hline cap81a-1 & 0.010 & 19.5 & 1.77 & 61 & 0.8 & 173 & 0.0819 & 2.2 & 0.2026 & 1.4 & 2.288 & 2.6 & 0.54 & 1243 & 87 & 1189 & 37 & 1209 & 116 & 4.3 & $\mathrm{Y}$ \\
\hline сар83a-1 & 0.006 & 11.9 & 1.07 & 32 & 0.8 & 91 & 0.0856 & 3.3 & 0.2331 & 1.4 & 2.750 & 3.6 & 0.39 & 1329 & 130 & 1351 & 42 & 1342 & 185 & -1.6 & $Y$ \\
\hline сар83a-2 & 0.001 & 13.7 & 1.33 & 37 & 0.1 & 105 & 0.0932 & 2.1 & 0.2427 & 1.4 & 3.120 & 2.5 & 0.54 & 1492 & 81 & 1401 & 43 & 1438 & 149 & 6.1 & N \\
\hline $\mathrm{cc}$ & & 12.9 & 1.13 & 43 & -0.5 & 123 & 0.0788 & 1.9 & 0.1963 & .3 & 32 & 2 & 58 & 67 & 74 & 1155 & 34 & 1159 & 95 & 1.0 & \\
\hline
\end{tabular}




\begin{tabular}{|c|c|c|c|c|c|c|c|c|c|c|c|c|c|c|c|c|c|c|c|c|c|}
\hline cap82b-1 & 0.004 & 7.4 & 0.91 & 23 & 0.9 & 66 & 0.0820 & 2.4 & 0.2028 & 1.4 & 2.293 & 2.8 & 0.50 & 1245 & 95 & 1191 & 36 & 1210 & 123 & 4.4 & $\mathrm{~N}$ \\
\hline cap104-1 & 0.000 & 2.2 & 0.20 & 18 & 0.0 & 52 & 0.0629 & 4.5 & 0.0763 & 1.4 & 0.661 & 4.7 & 0.30 & 704 & 191 & 474 & 14 & 515 & 61 & 32.7 & $\mathrm{~N}$ \\
\hline сар103a-1 & 0.002 & 6.9 & 0.36 & 96 & 0.4 & 271 & 0.0529 & 2.4 & 0.0483 & 1.4 & 0.352 & 2.8 & 0.49 & 324 & 110 & 304 & 8 & 307 & 20 & 6.2 & $\mathrm{~N}$ \\
\hline dro2b-1 & -0.001 & 9.5 & 0.80 & 26 & -0.2 & 73 & 0.0819 & 2.0 & 0.2109 & 1.4 & 2.382 & 2.4 & 0.57 & 1244 & 76 & 1234 & 37 & 1237 & 109 & 0.8 & $\mathrm{~N}$ \\
\hline dro2c-1 & 0.000 & 6.7 & 0.55 & 44 & 0.1 & 124 & 0.0587 & 2.2 & 0.0859 & 1.4 & 0.695 & 2.6 & 0.53 & 556 & 96 & 531 & 15 & 536 & 36 & 4.4 & $\mathrm{~N}$ \\
\hline dro2d-1 & 0.001 & 2.5 & 0.15 & 16 & 0.5 & 45 & 0.0630 & 3.1 & 0.0905 & 1.4 & 0.786 & 3.4 & 0.40 & 708 & 133 & 559 & 16 & 589 & 53 & 21.1 & $\mathrm{~N}$ \\
\hline dro3a-1 & -0.002 & 2.9 & 0.20 & 20 & -1.6 & 57 & 0.0557 & 3.7 & 0.0820 & 1.4 & 0.630 & 3.9 & 0.36 & 442 & 164 & 508 & 15 & 496 & 49 & -15.0 & $\mathrm{~N}$ \\
\hline dro3b-1 & 0.000 & 15.3 & 1.00 & 73 & 0.0 & 208 & 0.0649 & 1.9 & 0.1221 & 1.4 & 1.093 & 2.4 & 0.60 & 772 & 80 & 743 & 22 & 750 & 51 & 3.8 & $\mathrm{~N}$ \\
\hline dro7a-1 & 0.003 & 20.5 & 1.94 & 45 & 0.2 & 129 & 0.0965 & 1.8 & 0.2616 & 1.4 & 3.482 & 2.3 & 0.60 & 1558 & 68 & 1498 & 45 & 1523 & 148 & 3.9 & $\mathrm{~N}$ \\
\hline dro7b-1 & 0.002 & 10.7 & 0.86 & 31 & 0.3 & 87 & 0.0816 & 1.9 & 0.2058 & 1.4 & 2.316 & 2.3 & 0.58 & 1237 & 74 & 1206 & 36 & 1217 & 103 & 2.4 & $\mathrm{~N}$ \\
\hline dros-1 & 0.003 & 3.4 & 0.23 & 11 & 1.5 & 30 & 0.0792 & 2.2 & 0.1921 & 1.4 & 2.097 & 2.6 & 0.53 & 1177 & 88 & 1133 & 34 & 1148 & 106 & 3.8 & $\mathrm{~N}$ \\
\hline dro10a-1 & -0.002 & 6.8 & 0.56 & 21 & -0.5 & 58 & 0.0789 & 2.0 & 0.1957 & 1.4 & 2.129 & 2.4 & 0.57 & 1170 & 78 & 1152 & 35 & 1158 & 99 & 1.6 & $\mathrm{~N}$ \\
\hline dro10b-1 & 0.002 & 5.2 & 0.34 & 21 & 0.7 & 60 & 0.0702 & 2.2 & 0.1475 & 1.4 & 1.428 & 2.6 & 0.53 & 935 & 92 & 887 & 26 & 901 & 74 & 5.1 & $\mathrm{~N}$ \\
\hline dro10c-1 & 0.000 & 6.1 & 0.61 & 13 & -0.1 & 37 & 0.0989 & 2.0 & 0.2801 & 1.4 & 3.820 & 2.4 & 0.56 & 1604 & 75 & 1592 & 49 & 1597 & 173 & 0.8 & $\mathrm{~N}$ \\
\hline dro11b-1 & -0.002 & 8.6 & 0.88 & 19 & -0.4 & 53 & 0.0972 & 1.9 & 0.2733 & 1.4 & 3.665 & 2.4 & 0.58 & 1572 & 72 & 1558 & 48 & 1564 & 163 & 0.9 & $\mathrm{~N}$ \\
\hline dro12a-1 & 0.003 & 12.2 & 0.71 & 83 & 0.5 & 235 & 0.0607 & 1.9 & 0.0893 & 1.4 & 0.748 & $\begin{array}{l}2.4 \\
2.4\end{array}$ & 0.57 & 628 & 83 & 552 & 16 & 567 & 35 & 12.1 & $\mathrm{~N}$ \\
\hline dro12b-1 & 0.002 & 27.8 & 2.72 & 62 & 0.1 & 175 & 0.0982 & 1.8 & 0.2726 & 1.4 & 3.690 & 2.3 & 0.60 & 1589 & 67 & 1554 & 48 & 1569 & 156 & 2.2 & $\mathrm{~N}$ \\
\hline dro14b-1 & 0.003 & 24.6 & 3.27 & 70 & 0.2 & 197 & 0.1338 & 1.8 & 0.2149 & 1.4 & 3.966 & 2.3 & 0.62 & 2149 & 63 & 1255 & 39 & 1627 & 170 & 41.6 & $\mathrm{~N}$ \\
\hline dro17a-1 & -0.002 & 25.0 & 2.76 & 48 & -0.1 & 135 & 0.1087 & 1.8 & 0.3199 & 1.4 & 4.794 & 2.3 & 0.61 & 1778 & 66 & 1789 & 56 & 1784 & 199 & -0.6 & $\mathrm{~N}$ \\
\hline dro17b-1 & 0.034 & 19.0 & 1.58 & 54 & 2.9 & 152 & 0.0839 & 2.3 & 0.2165 & 1.4 & 2.503 & 2.7 & 0.53 & 1289 & 89 & 1263 & 39 & 1273 & 128 & 2.0 & Y \\
\hline dro17c-1 & 0.006 & 20.8 & $\begin{array}{l}1.68 \\
1.68\end{array}$ & 62 & 0.5 & 177 & $\begin{array}{l}0.0810 \\
0\end{array}$ & 2.2 & 0.2051 & $\begin{array}{l}1.4 \\
1.4\end{array}$ & 2.291 & 2.6 & 0.53 & 1221 & 87 & 1203 & 37 & 1209 & 115 & 1.5 & Y \\
\hline dro16a-1 & 0.008 & 59.9 & 7.66 & 121 & 0.2 & 343 & 0.1271 & 0.7 & 0.3051 & 1.4 & 5.345 & 1.6 & 0.89 & 2058 & 25 & 1716 & 54 & 1876 & 157 & 16.6 & Y \\
\hline dro16c-1 & 0.009 & 21.8 & 1.68 & 84 & 0.7 & 239 & 0.0768 & 1.9 & 0.1617 & 1.6 & 1.713 & 2.5 & 0.63 & 1117 & 76 & 966 & 32 & 1014 & 82 & 13.5 & Y \\
\hline dro19a-1 & -0.003 & 24.6 & 2.01 & 78 & -0.2 & 222 & 0.0793 & 1.8 & 0.1942 & 1.4 & 2.123 & 2.3 & 0.60 & 1179 & 72 & 1144 & 34 & 1156 & 94 & 3.0 & $\mathrm{~N}$ \\
\hline dro21b-1 & 0.003 & 4.4 & 0.22 & 55 & 1.2 & 156 & 0.0588 & 2.8 & 0.0503 & 1.4 & 0.408 & 3.1 & 0.44 & 559 & 122 & 316 & 9 & 347 & 25 & 43.4 & $\mathrm{~N}$ \\
\hline dro22-1 & 0.000 & 11.6 & 0.94 & 36 & 0.0 & 102 & 0.0800 & 1.9 & 0.2002 & 1.4 & 2.209 & 2.3 & 0.59 & 1198 & 73 & 1176 & 35 & 1184 & 99 & 1.8 & $\mathrm{~N}$ \\
\hline dro24c-1 & -0.002 & 21.5 & 1.62 & 88 & -0.2 & 250 & 0.0737 & 1.8 & 0.1530 & 1.4 & 1.554 & 2.3 & 0.60 & 1032 & 74 & 918 & 27 & 952 & 70 & 11.1 & $\mathrm{~N}$ \\
\hline dro24b-1 & 0.002 & 9.4 & 0.87 & 25 & 0.4 & 72 & 0.0911 & 2.3 & 0.2292 & 1.5 & 2.879 & 2.8 & 0.54 & 1449 & 89 & 1330 & 45 & 1377 & 151 & 8.2 & $\mathrm{~N}$ \\
\hline dro31a-1 & -0.002 & 5.1 & 0.33 & 34 & -0.9 & 97 & 0.0575 & 3.1 & 0.0917 & 1.4 & 0.727 & 3.3 & 0.41 & 511 & 134 & 566 & 16 & 555 & 48 & -10.8 & $\mathrm{~N}$ \\
\hline dro32a-1 & 0.000 & 22.4 & 1.78 & 77 & 0.0 & 218 & 0.0787 & 1.8 & 0.1827 & 1.4 & 1.982 & 2.3 & 0.60 & 1164 & 72 & 1082 & 32 & 1109 & 88 & 7.0 & $\mathrm{~N}$ \\
\hline dro32b-1 & 0.000 & 33.2 & 3.62 & 67 & 0.0 & 190 & 0.1082 & 1.8 & 0.3120 & 1.4 & 4.657 & 2.3 & 0.60 & 1770 & 66 & 1751 & 54 & 1759 & 194 & 1.1 & $\mathrm{~N}$ \\
\hline dro33b-1 & 0.001 & 66.8 & 9.36 & 112 & 0.0 & 317 & 0.1394 & 1.8 & 0.3779 & 1.4 & 7.266 & 2.2 & 0.60 & 2220 & 62 & 2066 & 65 & 2145 & 287 & 6.9 & $\mathrm{~N}$ \\
\hline dro34a-1 & 0.061 & 7.1 & 0.46 & 53 & $\begin{array}{l}13.1 \\
13\end{array}$ & 150 & 0.0652 & 8.9 & 0.0844 & $\begin{array}{l}1.5 \\
\end{array}$ & 0.759 & 9.0 & 0.17 & 779 & 375 & 523 & 17 & 573 & 131 & 33.0 & Y \\
\hline dro34b-1 & -0.001 & 26.9 & 2.96 & 57 & 0.0 & 161 & 0.1090 & 1.8 & 0.3040 & 1.4 & 4.570 & 2.3 & 0.60 & 1783 & 66 & 1711 & 53 & 1744 & 190 & 4.0 & $\mathrm{~N}$ \\
\hline dro36-1 & -0.002 & 17.0 & 1.17 & 83 & $\begin{array}{l}-0.2 \\
-0\end{array}$ & 235 & 0.0666 & 1.9 & 0.1315 & 1.3 & 1.208 & 2.3 & 0.58 & 825 & 78 & 797 & 23 & 804 & 55 & 3.4 & $\mathrm{~N}$ \\
\hline dro35b-1 & -0.001 & 1.7 & 0.14 & 6 & -0.7 & 16 & 0.0717 & 3.7 & 0.1930 & 1.4 & 1.907 & 4.0 & 0.36 & 977 & 151 & 1137 & 35 & 1084 & 143 & -16.4 & $\mathrm{~N}$ \\
\hline dro37b-1 & -0.001 & 7.4 & 0.59 & 32 & -0.2 & 91 & 0.0776 & 3.4 & 0.1443 & 1.3 & 1.545 & 3.6 & 0.35 & 1138 & 135 & 869 & 24 & 948 & 108 & 23.6 & $\mathrm{~N}$ \\
\hline dro37c-1 & 0.005 & $\begin{array}{l}1.4 .3 \\
\end{array}$ & $\begin{array}{l}1.00 \\
1.00\end{array}$ & 44 & 0.6 & 126 & 0.0799 & $\begin{array}{l}3.4 \\
3.2\end{array}$ & 0.1930 & 1.2 & 2.126 & $\begin{array}{l}3.0 \\
3.4\end{array}$ & 0.35 & 1195 & 126 & 1138 & 30 & 1157 & 138 & 4.8 & $\mathrm{~N}$ \\
\hline dro65b-1 & 0.002 & 33.8 & 3.33 & 81 & 0.1 & 229 & 0.0985 & 3.2 & 0.2739 & 1.2 & 3.720 & 3.4 & 0.35 & 1596 & 119 & 1560 & 42 & 1576 & 229 & 2.2 & $\mathrm{~N}$ \\
\hline dro66b-1 & 0.000 & 6.7 & 0.53 & 23 & 0.1 & 64 & 0.0793 & 3.3 & 0.1870 & 1.3 & 2.045 & 3.5 & 0.35 & 1180 & 131 & 1105 & 30 & 1131 & 138 & 6.3 & $\mathrm{~N}$ \\
\hline dro66c-1 & -0.004 & 4.2 & 0.28 & 54 & -1.6 & 154 & 0.0522 & 3.9 & 0.0487 & 1.2 & 0.350 & 4.1 & 0.30 & 295 & 180 & 306 & 8 & 305 & 29 & -3.8 & $\mathrm{~N}$ \\
\hline dro64c-1 & 0.005 & 24.2 & 2.62 & 53 & 0.3 & 150 & 0.1098 & 3.2 & 0.3031 & 1.2 & 4.588 & 3.4 & 0.36 & 1796 & 116 & 1707 & 48 & 1747 & 276 & 5.0 & $\mathrm{~N}$ \\
\hline dro64e-1 & 0.007 & 20.6 & 1.20 & 145 & 0.6 & 412 & 0.0570 & 3.2 & 0.0953 & 1.2 & 0.750 & 3.4 & 0.35 & 493 & 142 & 587 & 15 & 568 & 51 & -19.1 & Y \\
\hline dro63f-1 & 0.005 & 2.9 & 0.24 & 11 & 2.7 & 31 & 0.0990 & 4.5 & 0.1772 & 1.4 & 2.419 & 4.7 & 0.29 & 1606 & 169 & 1051 & 31 & 1248 & 209 & 34.5 & $\mathrm{~N}$ \\
\hline dro63e-1 & 0.000 & 4.0 & 0.41 & 10 & 0.0 & 28 & 0.1013 & 3.5 & 0.2714 & 1.3 & 3.790 & 3.8 & 0.34 & 1648 & 132 & 1548 & 44 & 1591 & 255 & 6.1 & $\mathrm{~N}$ \\
\hline dro63b-1 & 0.000 & 1.8 & 0.14 & 6 & -0.2 & 18 & 0.0733 & 4.5 & 0.1952 & 1.2 & 1.973 & 4.7 & 0.26 & 1022 & 183 & 1150 & 31 & 1106 & 172 & -12.5 & $\mathrm{~N}$ \\
\hline dro61b-1 & -0.001 & 2.3 & 0.15 & 16 & -0.8 & 46 & 0.0616 & 4.7 & 0.0949 & 1.2 & 0.807 & 4.9 & 0.25 & 661 & 203 & 585 & 15 & 601 & 77 & 11.5 & $\mathrm{~N}$ \\
\hline dro61a-1 & 0.000 & 2.2 & 0.14 & 30 & 0.1 & 86 & 0.0592 & 6.0 & 0.0494 & 1.2 & 0.403 & 6.1 & 0.20 & 574 & 259 & 311 & 8 & 344 & 49 & 45.8 & $\mathrm{~N}$ \\
\hline dro6ob-1 & -0.001 & 5.6 & 0.55 & 14 & -0.3 & 41 & 0.0940 & 3.3 & 0.2651 & 1.2 & 3.437 & 3.5 & 0.35 & 1509 & 124 & 1516 & 42 & 1513 & 220 & -0.5 & $\mathrm{~N}$ \\
\hline dro60e-1 & 0.000 & 21.1 & 1.71 & 71 & 0.0 & 203 & 0.0810 & 3.2 & 0.2022 & 1.2 & 2.259 & 3.4 & 0.35 & 1221 & 125 & 1187 & 31 & 1199 & 145 & 2.8 & $\mathrm{~N}$ \\
\hline dro6od-1 & 0.005 & 48.0 & 5.28 & 163 & 0.2 & 462 & 0.1105 & 3.2 & 0.2104 & 2.3 & 3.206 & 3.9 & 0.58 & 1808 & 116 & 1231 & 62 & 1459 & 228 & 31.9 & $\mathrm{~N}$ \\
\hline dro60c-1 & 0.005 & 12.3 & 1.27 & 28 & 0.6 & 79 & 0.1077 & 3.2 & 0.3126 & 1.2 & 4.641 & 3.4 & 0.35 & 1761 & 117 & 1753 & 48 & 1757 & 279 & 0.4 & $\mathrm{~N}$ \\
\hline dro59b-1 & 0.004 & 31.9 & 3.17 & 79 & 0.2 & 225 & 0.1000 & 3.2 & 0.2856 & 1.2 & 3.939 & 3.4 & 0.35 & 1625 & 118 & 1620 & 44 & 1622 & 241 & 0.3 & $\mathrm{~N}$ \\
\hline dro58d-1 & -0.003 & 27.2 & 2.81 & 68 & -0.2 & 192 & 0.1010 & 3.2 & 0.2875 & 1.2 & 4.004 & $\begin{array}{l}3.4 \\
3.4\end{array}$ & 0.36 & 1643 & 118 & 1629 & 45 & 1635 & 245 & 0.8 & $\mathrm{~N}$ \\
\hline dro58c-1 & 0.001 & 14.6 & 1.44 & 38 & 0.1 & 107 & 0.0989 & 3.2 & 0.2828 & 1.2 & 3.858 & 3.4 & 0.36 & 1604 & 119 & 1605 & 44 & 1605 & 238 & -0.1 & $\mathrm{~N}$ \\
\hline dro58a-1 & 0.000 & 7.9 & 0.47 & 59 & 0.0 & 168 & 0.0588 & 3.4 & 0.0944 & 1.2 & 0.765 & 3.6 & 0.34 & 559 & 146 & 581 & 15 & 577 & 54 & -4.0 & $\mathrm{~N}$ \\
\hline dro57-1 & -0.003 & 2.3 & 0.24 & 7 & -1.9 & 21 & 0.0883 & 4.7 & 0.2125 & 1.3 & 2.587 & 4.8 & 0.26 & 1388 & 179 & 1242 & 34 & 1297 & 226 & 10.5 & $\mathrm{~N}$ \\
\hline dro56c-1 & 0.001 & 22.7 & 4.54 & 33 & 0.1 & 93 & 0.2002 & 3.2 & 0.5045 & 1.3 & 13.926 & 3.4 & 0.38 & 2828 & 104 & 2633 & 84 & 2745 & 682 & 6.9 & $\mathrm{~N}$ \\
\hline dro56a-1 & 0.033 & 2.4 & 0.20 & 9 & 18.4 & 25 & 0.0843 & 13.2 & 0.1952 & 1.5 & 2.270 & 13.2 & 0.12 & 1300 & 511 & 1150 & 39 & 1203 & 478 & 11.6 & Y \\
\hline dro55a-1 & 0.000 & 57.2 & 6.07 & 148 & 0.0 & 420 & 0.1057 & 3.2 & 0.2850 & 1.3 & 4.152 & 3.4 & 0.38 & 1726 & 117 & 1616 & 47 & 1665 & 254 & 6.3 & $\mathrm{~N}$ \\
\hline dro55b-1 & 0.000 & 5.8 & 0.36 & 43 & -0.1 & 122 & 0.0609 & 3.5 & 0.0979 & 1.2 & 0.823 & $\begin{array}{l}3.7 \\
3.7\end{array}$ & 0.32 & 637 & 150 & 602 & 15 & 610 & 60 & 5.4 & $\mathrm{~N}$ \\
\hline dro54-1 & 0.003 & 12.5 & 0.70 & 133 & 0.4 & 377 & 0.0590 & 3.3 & 0.0685 & 1.2 & 0.557 & 3.5 & 0.35 & 568 & 142 & 427 & 11 & 450 & 39 & 24.9 & $\mathrm{~N}$ \\
\hline dro51a-1 & 0.004 & 3.7 & 0.33 & 15 & 1.8 & 42 & 0.1049 & 4.1 & 0.1868 & 1.3 & 2.702 & 4.3 & 0.29 & 1712 & 153 & 1104 & 31 & 1329 & 214 & 35.5 & $\mathrm{~N}$ \\
\hline
\end{tabular}




\begin{tabular}{|c|c|c|c|c|c|c|c|c|c|c|c|c|c|c|c|c|c|c|c|c|c|}
\hline dro52d-1 & -0.001 & 5.3 & 0.42 & 26 & -0.2 & 74 & 0.0773 & 3.3 & 0.1518 & 1.6 & 1.619 & 3.6 & 0.43 & 1129 & 131 & 911 & 31 & 977 & 113 & 19.3 & $\mathrm{~N}$ \\
\hline сус1a-1 & 0.003 & 28.9 & $\begin{array}{l}6.59 \\
\end{array}$ & 32 & 0.2 & 89 & 0.2277 & 3.2 & 0.5528 & 1.2 & 17.351 & 3.4 & 0.36 & 3036 & 102 & 2837 & 85 & 2954 & 791 & 6.6 & $\mathrm{~N}$ \\
\hline сусз-1 & 0.002 & 22.0 & 2.08 & 48 & 0.2 & 137 & 0.0948 & 3.2 & 0.2684 & 1.4 & 3.508 & 3.5 & 0.40 & 1524 & 120 & 1533 & 48 & 1529 & 222 & -0.6 & $\mathrm{~N}$ \\
\hline сус5-1 & 0.003 & 29.9 & 3.01 & 59 & 0.1 & 168 & 0.1015 & 3.2 & 0.2942 & 1.2 & 4.118 & 3.4 & 0.35 & 1652 & 118 & 1662 & 45 & 1658 & 250 & -0.6 & $\mathrm{~N}$ \\
\hline сус7а-1 & -0.001 & 52.4 & 5.66 & 101 & 0.0 & 285 & 0.1073 & 3.2 & 0.3098 & 1.2 & 4.583 & 3.4 & 0.35 & 1754 & 116 & 1740 & 47 & 1746 & 275 & 0.8 & $\mathrm{~N}$ \\
\hline сус9-1 & 0.000 & $\begin{array}{l}29.4 \\
29.6\end{array}$ & 3.26 & 55 & 0.0 & 155 & 0.1095 & $\begin{array}{l}3.2 \\
3.2\end{array}$ & 0.3274 & 1.2 & 4.942 & $\begin{array}{l}3.4 \\
3.4\end{array}$ & 0.35 & 1791 & 116 & 1826 & 50 & 1809 & 294 & $\begin{array}{l}0.0 \\
-1.9\end{array}$ & $\mathrm{~N}$ \\
\hline сус10b-1 & 0.002 & 30.3 & 2.40 & 98 & 0.1 & 277 & 0.0792 & 3.2 & 0.1929 & 1.2 & 2.107 & 3.4 & 0.35 & 1177 & 126 & 1137 & 30 & 1151 & 136 & 3.4 & $\mathrm{~N}$ \\
\hline cyc11b-1 & 0.001 & 24.2 & 2.58 & 48 & 0.0 & 136 & 0.1061 & 3.2 & 0.3074 & 1.2 & 4.496 & 3.4 & 0.35 & 1733 & 117 & 1728 & 47 & 1730 & 271 & 0.3 & $\mathrm{~N}$ \\
\hline сус14b-1 & 0.012 & 145.2 & 22.53 & 208 & 0.1 & 589 & 0.1535 & 0.4 & 0.4182 & 1.1 & 8.849 & 1.2 & 0.93 & 2385 & 15 & 2252 & 61 & 2323 & 199 & 5.6 & $Y$ \\
\hline сус $15 \mathrm{a}-1$ & -0.001 & 15.3 & 1.23 & 46 & -0.1 & 131 & 0.0796 & 3.2 & 0.2002 & 1.2 & 2.199 & 3.4 & 0.35 & 1188 & 126 & 1177 & 31 & 1181 & 142 & 1.0 & $\mathrm{~N}$ \\
\hline сус 30 a- & 0.002 & 51.6 & 10.42 & 60 & 0.0 & 171 & 0.2014 & $\begin{array}{l}3.2 \\
3.2\end{array}$ & $\begin{array}{l}0.5250 \\
0.02\end{array}$ & 1.2 & 14.576 & $\begin{array}{l}3.4 \\
3.4\end{array}$ & 0.36 & 2837 & 104 & 2720 & 82 & 2788 & 699 & 4.1 & $\mathrm{~N}$ \\
\hline сус $17-1$ & -0.002 & 6.6 & 0.56 & 20 & -0.6 & 57 & 0.0795 & 3.4 & 0.1990 & 1.2 & 2.183 & 3.6 & 0.33 & 1186 & 133 & 1170 & 31 & 1176 & 147 & 1.3 & $\mathrm{~N}$ \\
\hline cyc20a-1 & -0.004 & 17.6 & 1.95 & 35 & -0.3 & 100 & 0.1065 & 3.2 & 0.3136 & 1.2 & 4.606 & 3.4 & 0.35 & 1741 & 117 & 1758 & 49 & 1750 & 278 & -1.0 & $\mathrm{~N}$ \\
\hline сус21-1 & 0.005 & 3.7 & 0.29 & 12 & 2.1 & 33 & 0.0935 & 3.8 & 0.2028 & 1.2 & 2.614 & 3.9 & 0.31 & 1498 & 142 & 1190 & 32 & 1305 & 191 & 20.5 & $\mathrm{~N}$ \\
\hline сус33с-1 & -0.004 & 23.6 & 2.63 & 45 & -0.3 & 127 & 0.1087 & 3.2 & 0.3209 & 1.2 & 4.811 & 3.4 & 0.35 & 1778 & 116 & 1794 & 50 & 1787 & 288 & -0.9 & $\mathrm{~N}$ \\
\hline сус34-1 & -0.002 & 87.9 & 9.38 & 183 & 0.0 & 519 & 0.1045 & 3.3 & 0.2913 & 1.4 & 4.200 & 3.6 & 0.39 & 1706 & 123 & 1648 & 52 & 1674 & 269 & 3.4 & $\mathrm{~N}$ \\
\hline сус34b-1 & 0.000 & 10.5 & 0.66 & 70 & -0.1 & 198 & 0.0614 & 3.3 & 0.0949 & 1.2 & 0.803 & 3.5 & 0.34 & 653 & 141 & 585 & 15 & 599 & 55 & 10.5 & $\mathrm{~N}$ \\
\hline сус57b-1 & 0.000 & 40.2 & 4.61 & 79 & 0.0 & 224 & 0.1141 & $\begin{array}{l}3.0 \\
3.2\end{array}$ & $\begin{array}{l}0.03182 \\
\end{array}$ & 1.2 & 5.005 & 3.4 & 0.36 & 1865 & 115 & 1781 & 49 & 1820 & 297 & 4.5 & $\mathrm{~N}$ \\
\hline cyc58b-1 & -0.001 & 8.6 & 0.50 & 70 & -0.2 & 198 & 0.0563 & 3.4 & 0.0770 & 1.2 & 0.598 & 3.6 & 0.33 & 463 & 151 & 478 & 12 & 476 & 43 & -3.3 & $\mathrm{~N}$ \\
\hline cyc91b-1 & -0.002 & 4.2 & 0.45 & 9 & -1.0 & 27 & 0.0986 & 3.4 & 0.2721 & 1.2 & 3.697 & 3.6 & 0.34 & 1597 & 127 & 1551 & 43 & 1571 & 241 & 2.9 & $\mathrm{~N}$ \\
\hline сус91c-1 & -0.002 & 38.6 & 10.87 & 38 & -0.1 & 107 & 0.2794 & 3.2 & 0.6146 & 1.2 & 23.674 & 3.4 & 0.36 & 3359 & 99 & 3088 & 97 & 3255 & 975 & 8.1 & $\mathrm{~N}$ \\
\hline сус93-1 & -0.005 & 12.0 & 0.72 & 127 & -0.8 & 361 & 0.0543 & 3.3 & 0.0563 & 1.2 & 0.421 & 3.5 & 0.35 & 383 & 146 & 353 & 9 & 357 & 29 & 7.9 & $\mathrm{~N}$ \\
\hline cyc90b-1 & 0.000 & 4.3 & 0.34 & 15 & 0.0 & 41 & 0.0764 & 3.5 & 0.1890 & 1.2 & 1.992 & 3.7 & 0.33 & 1107 & 140 & 1116 & 30 & 1113 & 140 & -0.8 & $\mathrm{~N}$ \\
\hline сус85-1 & -0.001 & 15.2 & 1.74 & 42 & -0.1 & 119 & 0.1134 & 3.2 & 0.2340 & 1.2 & 3.658 & 3.4 & 0.36 & 1854 & 115 & 1355 & 38 & 1562 & 227 & 26.9 & $\mathrm{~N}$ \\
\hline сус84a- 1 & 0.005 & 9.9 & 0.50 & 135 & 0.9 & 382 & 0.0580 & 3.3 & 0.0490 & 1.2 & 0.391 & $\begin{array}{l}3.4 \\
3.5\end{array}$ & 0.35 & 529 & 144 & 308 & 8 & 335 & 28 & 41.8 & $\mathrm{~N}$ \\
\hline сус84c-1 & 0.003 & 52.9 & 4.20 & 176 & 0.1 & 498 & 0.0797 & 3.2 & 0.1990 & 1.2 & 2.187 & 3.4 & 0.35 & 1190 & 125 & 1170 & 31 & 1177 & 141 & 1.7 & $\mathrm{~N}$ \\
\hline сус82a-1 & -0.002 & 12.9 & 1.31 & 30 & -0.2 & 85 & 0.0982 & 3.2 & 0.2830 & 1.2 & 3.834 & 3.4 & 0.36 & 1591 & 119 & 1607 & 44 & 1600 & 237 & -1.0 & $\mathrm{~N}$ \\
\hline сус50-1 & $\begin{array}{l}-0.002 \\
-0.003\end{array}$ & 10.8 & 0.67 & 122 & -0.5 & 346 & $\begin{array}{l}0.0567 \\
\end{array}$ & $\begin{array}{l}3.2 \\
3.3\end{array}$ & 0.0594 & 1.2 & 0.465 & $\begin{array}{l}3.4 \\
3.5\end{array}$ & 0.34 & 481 & 146 & 372 & 9 & 388 & 33 & 22.5 & $\mathrm{~N}$ \\
\hline сус49c-1 & 0.000 & 2.6 & 0.23 & 10 & 0.2 & 30 & 0.0863 & 4.0 & 0.1767 & 1.4 & 2.103 & 4.2 & 0.32 & 1344 & 153 & 1049 & 31 & 1150 & 165 & 22.0 & $\mathrm{~N}$ \\
\hline cyc49b-1 & 0.001 & 1.4 & 0.06 & 11 & $\begin{array}{l}0.6 \\
1.6\end{array}$ & 31 & 0.0603 & 6.7 & 0.0869 & $\begin{array}{l}1.4 \\
1.2\end{array}$ & 0.723 & $\begin{array}{l}6.2 \\
6.8\end{array}$ & 0.18 & 615 & 291 & 537 & 14 & 552 & 96 & 12.7 & $\mathrm{~N}$ \\
\hline сус49a-1 & 0.002 & 58.2 & 8.55 & 109 & 0.0 & 309 & 0.1463 & 3.2 & 0.3728 & 1.2 & 7.521 & 3.4 & 0.35 & 2304 & 109 & 2042 & 57 & 2176 & 418 & 11.3 & $\mathrm{~N}$ \\
\hline сус48a-1 & -0.001 & 24.0 & 2.81 & 55 & -0.1 & 157 & 0.1156 & 3.2 & 0.2988 & 1.4 & 4.765 & 3.5 & 0.40 & 1890 & 114 & 1686 & 54 & 1779 & 290 & 10.8 & $\mathrm{~N}$ \\
\hline cyc47-1 & 0.002 & $\begin{array}{c}24.0 \\
5.6\end{array}$ & 0.42 & 19 & 0.7 & 55 & 0.0790 & $\begin{array}{l}3.2 \\
3.4\end{array}$ & $\begin{array}{l}0.2500 \\
0.1996\end{array}$ & $\begin{array}{l}1.4 \\
1.2\end{array}$ & 2.173 & $\begin{array}{l}3.5 \\
3.6\end{array}$ & $\begin{array}{l}0.40 \\
0.33\end{array}$ & 1172 & 134 & 1173 & 31 & 1173 & 147 & $\begin{array}{l}1.0 \\
-0.1\end{array}$ & $\mathrm{~N}$ \\
\hline сус45a- 1 & 0.004 & 27.4 & 2.58 & 75 & 0.2 & 213 & 0.0963 & 3.2 & 0.2601 & 1.2 & 3.454 & 3.4 & 0.35 & 1554 & 119 & 1490 & 40 & 1517 & 214 & 4.1 & $\mathrm{~N}$ \\
\hline cyc45b-1 & 0.013 & 13.6 & 0.91 & 84 & 1.6 & 239 & 0.0678 & 3.9 & 0.1168 & 1.3 & 1.091 & 4.1 & 0.31 & 861 & 162 & 712 & 19 & 749 & 87 & 17.3 & Y \\
\hline сус46c-1 & 0.002 & 21.5 & 2.13 & 55 & 0.2 & 155 & 0.1000 & 3.2 & 0.2840 & 1.2 & 3.916 & 3.4 & 0.36 & 1624 & 118 & 1612 & 45 & 1617 & 240 & 0.8 & $\mathrm{~N}$ \\
\hline cyc44a-1 & -0.004 & 19.3 & 1.76 & 60 & -0.3 & 169 & 0.0876 & 3.2 & 0.2305 & 1.4 & 2.786 & 3.5 & 0.40 & 1374 & 123 & 1337 & 42 & 1352 & 180 & 2.7 & $\mathrm{~N}$ \\
\hline cyc441-1 & 0.004 & 5.9 & 0.28 & 90 & $\begin{array}{l}-0.3 \\
1.3\end{array}$ & 255 & 0.0567 & $\begin{array}{l}.2 \\
3.6\end{array}$ & $\begin{array}{l}0.20500 \\
0.0500\end{array}$ & $\begin{array}{l}1.4 \\
1.2\end{array}$ & 0.391 & $\begin{array}{l}3.5 \\
3.8\end{array}$ & $\begin{array}{l}0.40 \\
0.31\end{array}$ & 480 & $\begin{array}{l}159 \\
159\end{array}$ & 315 & $\begin{array}{c}42 \\
8\end{array}$ & 335 & 30 & $\begin{array}{l}2.1 \\
34.5\end{array}$ & $\mathrm{~N}$ \\
\hline сус40-1 & 0.000 & 4.0 & 0.36 & 17 & -0.1 & 47 & $\begin{array}{l}0.0873 \\
0.087\end{array}$ & $\begin{array}{l}3.0 \\
3.6\end{array}$ & $\begin{array}{l}0.0340 \\
0.1842\end{array}$ & $\begin{array}{l}1.2 \\
1.3\end{array}$ & $\begin{array}{l}0.3917 \\
2.217\end{array}$ & $\begin{array}{l}3.0 \\
3.9\end{array}$ & 0.33 & 1367 & 141 & 1090 & 30 & $\begin{array}{l}303 \\
1186\end{array}$ & 160 & $\begin{array}{l}3.5 \\
20.2\end{array}$ & $\mathrm{~N}$ \\
\hline сус25a-1 & 0.015 & 10.6 & 0.59 & 137 & 2.5 & 388 & 0.0544 & 5.5 & 0.0564 & 1.2 & 0.423 & 5.7 & 0.21 & 386 & 249 & 354 & 9 & 358 & 47 & 8.4 & Y \\
\hline cyc25b-1 & -0.002 & 19.3 & 1.96 & 49 & -0.1 & 139 & 0.0993 & 3.2 & 0.2943 & 1.2 & 4.031 & 3.4 & 0.35 & 1611 & 119 & 1663 & 45 & 1640 & 246 & -3.2 & $\mathrm{~N}$ \\
\hline сус $38 \mathrm{c}-1$ & 0.000 & 7.9 & 0.60 & 37 & 0.0 & 106 & 0.0767 & $\begin{array}{l}3.2 \\
3.3\end{array}$ & $\begin{array}{l}0.2597 \\
\end{array}$ & 1.2 & 1.688 & $\begin{array}{l}3.4 \\
3.5\end{array}$ & 0.34 & 1112 & 131 & 955 & 25 & 1004 & 113 & 14.1 & $\mathrm{~N}$ \\
\hline сус38b-1 & 0.003 & 3.3 & 0.15 & 49 & 1.4 & 138 & 0.0561 & 4.4 & 0.0521 & 1.2 & 0.403 & 4.6 & 0.26 & 458 & 196 & 327 & 8 & 344 & 37 & 28.5 & $\mathrm{~N}$ \\
\hline сус38a- -1 & 0.004 & 19.5 & 1.48 & 74 & 0.3 & 210 & 0.0776 & 3.2 & 0.1949 & 1.2 & 2.086 & 3.4 & 0.35 & 1138 & 129 & 1148 & 30 & 1144 & 136 & -0.9 & $\mathrm{~N}$ \\
\hline сус 39-1 & -0.001 & 4.5 & 0.30 & 36 & -0.5 & 101 & 0.0633 & 3.7 & 0.0953 & 1.2 & 0.832 & 3.9 & 0.31 & 718 & 157 & 587 & 15 & 615 & 64 & 18.2 & $\mathrm{~N}$ \\
\hline сус37b-1 & -0.002 & 15.7 & 1.56 & 43 & -0.2 & 122 & 0.0976 & 3.2 & 0.2776 & 1.2 & 3.736 & 3.4 & 0.35 & 1579 & 120 & 1579 & 43 & 1579 & 231 & 0.0 & $\mathrm{~N}$ \\
\hline сус $37 \mathrm{c}$ & -0.001 & 14.3 & 1.13 & 60 & -0.1 & 169 & 0.0774 & $\begin{array}{l}3.2 \\
3.2\end{array}$ & 0.1841 & 1.2 & 1.965 & $\begin{array}{l}3.4 \\
3.4\end{array}$ & 0.35 & 1131 & 128 & 1089 & 28 & 1103 & 128 & 3.7 & $\mathrm{~N}$ \\
\hline сус60с-1 & 0.003 & 13.8 & 0.95 & 69 & 0.3 & 197 & 0.0706 & 3.2 & 0.1559 & 1.3 & 1.518 & 3.5 & 0.37 & 946 & 132 & 934 & 25 & 938 & 102 & 1.3 & $\mathrm{~N}$ \\
\hline сус59a-1 & 0.011 & 42.6 & 4.63 & 100 & 0.4 & 282 & 0.1079 & $\begin{array}{l}0.2 \\
1.0\end{array}$ & 0.3207 & 1.2 & 4.770 & 1.6 & 0.76 & 1764 & 37 & $\begin{array}{l}304 \\
1793\end{array}$ & 49 & 1780 & 140 & -1.7 & Y \\
\hline сус97a-1 & 0.001 & 7.7 & 0.80 & 19 & 0.2 & 55 & 0.1050 & 3.2 & 0.3114 & 1.2 & 4.508 & 3.4 & 0.35 & 1714 & 119 & 1748 & 48 & 1732 & 274 & -2.0 & $\mathrm{~N}$ \\
\hline сус67-1 & 0.000 & 3.8 & 0.35 & 11 & 0.0 & 31 & 0.0922 & 3.5 & 0.2704 & 1.2 & 3.440 & 3.7 & 0.32 & 1472 & 133 & 1543 & 41 & 1514 & 230 & -4.8 & $\mathrm{~N}$ \\
\hline сус $71 \mathrm{~b}-1$ & $\begin{array}{l}0.0002 \\
-0.002\end{array}$ & $\begin{array}{c}5.0 \\
18.0\end{array}$ & 1.36 & 74 & $\begin{array}{l}0.2 \\
-0.2\end{array}$ & 211 & $\begin{array}{l}0.0522 \\
0.0738\end{array}$ & $\begin{array}{l}.5 \\
3.2\end{array}$ & $\begin{array}{l}0.21844 \\
0.1842\end{array}$ & $\begin{array}{l}1.2 \\
1.2\end{array}$ & $\begin{array}{l}0.440 \\
1.876\end{array}$ & $\begin{array}{l}3.1 \\
3.4\end{array}$ & $\begin{array}{l}0.32 \\
0.35\end{array}$ & 1037 & $\begin{array}{l}129 \\
129\end{array}$ & 1090 & 28 & 1072 & 123 & $\begin{array}{l}-4.0 \\
-5.1\end{array}$ & $\mathrm{~N}$ \\
\hline суст2-1 & 0.032 & 9.1 & 0.89 & 18 & 5.4 & 52 & 0.0987 & 3.4 & 0.2770 & 1.3 & 3.770 & 3.6 & 0.35 & 1600 & 125 & 1576 & 45 & 1586 & 243 & 1.5 & $\mathrm{Y}$ \\
\hline сус77a-1 & 0.030 & 92.9 & 9.97 & 247 & 0.5 & 700 & 0.1068 & $\begin{array}{l}.4 .6 \\
0.6\end{array}$ & 0.2133 & 1.9 & 3.141 & 2.0 & 0.95 & 1746 & 23 & 1246 & 51 & 1443 & 119 & 28.6 & Y \\
\hline сус78a-1 & -0.001 & 26.8 & 1.77 & 141 & -0.1 & 399 & 0.0648 & 3.2 & 0.1077 & 1.2 & 0.962 & 3.4 & 0.35 & 767 & 134 & 659 & 17 & 684 & 64 & 14.1 & $\mathrm{~N}$ \\
\hline сус $78 b-1$ & -0.003 & 3.4 & 0.22 & 41 & -1.6 & 116 & 0.0530 & 3.8 & 0.0471 & 1.2 & 0.344 & 4.0 & 0.30 & 327 & 174 & 297 & 7 & 300 & 28 & 9.4 & $\mathrm{~N}$ \\
\hline сус $79-1$ & 0.000 & 8.8 & 0.70 & 24 & -0.1 & 69 & 0.0792 & 3.3 & 0.2047 & 1.2 & 2.237 & 3.5 & 0.35 & 1178 & 129 & 1201 & 32 & 1193 & 147 & -1.9 & $\mathrm{~N}$ \\
\hline cy $109 \mathrm{e}-1$ & -0.001 & 61.3 & 7.07 & 102 & 0.0 & 288 & 0.1141 & 3.2 & 0.3280 & 1.2 & 5.160 & 3.4 & 0.36 & 1866 & 115 & 1829 & 51 & 1846 & 305 & 2.0 & $\mathrm{~N}$ \\
\hline сус $110-1$ & 0.002 & 24.6 & 1.94 & 73 & 0.1 & 208 & 0.0791 & 3.2 & 0.1937 & 1.2 & 2.112 & 3.4 & 0.36 & 1175 & 126 & 1141 & 30 & $\begin{array}{l}1153 \\
1153\end{array}$ & 137 & 2.8 & $\mathrm{~N}$ \\
\hline cyc118a-1 & 0.004 & 111.3 & 11.84 & 292 & 0.1 & 827 & 0.1061 & 3.2 & 0.2216 & 1.4 & 3.240 & 3.5 & 0.40 & 1733 & 116 & 1290 & 40 & 1467 & 206 & 25.6 & $\mathrm{~N}$ \\
\hline cyc118b-1 & 0.001 & 1.6 & 0.08 & 14 & 1.3 & 40 & 0.0610 & 6.3 & 0.0656 & 1.2 & 0.552 & 6.4 & 0.19 & 640 & 269 & 409 & 10 & 446 & 69 & 36.1 & $\mathrm{~N}$ \\
\hline
\end{tabular}

** uncertainty on U concentration c. $25 \%$ 
*** discordance is percentage difference between ${ }^{207} \mathrm{~Pb}{ }^{206} \mathrm{~Pb}$ and ${ }^{206} \mathrm{~Pb} b^{238} \mathrm{U}$ ages $\mathrm{Cm}-\mathrm{Pb}$ corr'd? = common lead corrected data Yes or No 
Table 3 - Multiple analyses of two youngest grains from sample CAP.

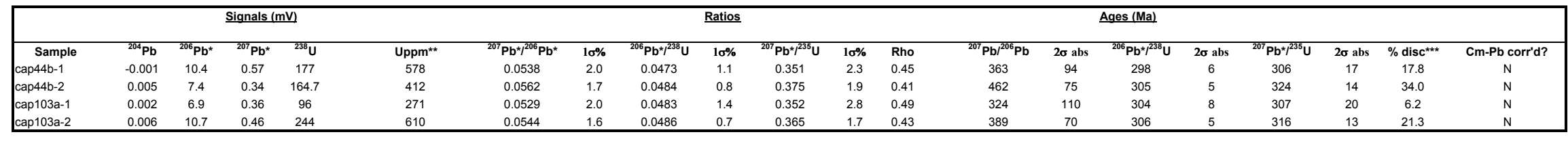

\section{${ }^{*}=$ radiogenic}

** uncertainty on U concentration c. $25 \%$

*** discordance is percentage difference between $207 \mathrm{~Pb} / 206 \mathrm{~Pb}$ and $206 \mathrm{~Pb} / 238 \mathrm{U}$ ages

$\mathrm{Cm}-\mathrm{Pb}$ corr'd? = common lead corrected data Yes or No 


\section{Table 4 - Hf analyses from two 305Ma grains from sample CAP}

\begin{tabular}{|c|c|c|c|c|c|c|c|c|c|c|c|c|c|c|c|}
\hline Sample & Total Hf (V) & ${ }^{77} \mathrm{Hf} /{ }^{17} \mathrm{Hf}$ & $1 \sigma \%$ & ${ }^{77} \mathrm{Hf} /{ }^{17} \mathrm{Hf}$ & $1 \sigma \%$ & ${ }^{176} \mathrm{Yb} /{ }^{17} \mathrm{Hf}$ & $1 \sigma \%$ & ${ }^{7 / 0} \mathrm{Lu} /{ }^{17} \mathrm{Hf}$ & $1 \sigma \%$ & Age & $1 \mathrm{~s}$ & EHf & $2 s$ & TDM & $2 s$ \\
\hline cap44b & 3.68 & 1.46727 & 0.0055 & 0.282264 & 0.0157 & 0.281 & 8.2 & 0.00129 & 7.7 & 305 & 3 & -11.3 & 1.7 & 1352 & 63 \\
\hline cap103a & 3.48 & 1.46731 & 0.0051 & 0.282257 & 0.0151 & 0.179 & 5.3 & 0.000861 & 4.8 & 305 & 4 & -11.5 & 1.6 & 1346 & 59 \\
\hline
\end{tabular}


Table 5 - All Hf analyses

\begin{tabular}{|c|c|c|c|c|c|c|c|c|c|c|c|c|c|c|c|}
\hline Sample & Total Hf (V) & ${ }^{7}{ }^{\circ} \mathrm{Hf} /{ }^{17} \mathrm{Hf}$ & $1 \sigma \%$ & ${ }^{70} \mathrm{Hf} /{ }^{17} \mathrm{Hf}$ & $1 \sigma \%$ & ${ }^{70} \mathrm{Yb} /{ }^{17} \mathrm{Hf}$ & $1 \sigma \%$ & ${ }^{70} \mathrm{Lu} /{ }^{17} \mathrm{Hf}$ & $1 \sigma \%$ & Age & $1 \mathrm{~s}$ & EHf & $2 s$ & TDM & $2 s$ \\
\hline dro2b & 1.02 & 1.46718 & 0.0074 & 0.282196 & 0.0274 & 0.113 & 61.0 & 0.00081 & 6.4 & 1234 & 18 & 7.4 & 3.2 & 1425 & 105 \\
\hline dro2d & 0.86 & 1.46715 & 0.0071 & 0.281974 & 0.0273 & 0.019 & 60.9 & 0.00014 & 6.3 & 559 & 8 & -15.5 & 2.9 & 1691 & 101 \\
\hline dro3a & 1.12 & 1.46737 & 0.0068 & 0.282036 & 0.0267 & 0.049 & 61.1 & 0.00036 & 7.2 & 508 & 7 & -14.5 & 2.8 & 1619 & 100 \\
\hline dro3b & 1.24 & 1.46721 & 0.0066 & 0.282029 & 0.0263 & 0.112 & 61.1 & 0.00080 & 7.3 & 743 & 11 & -9.7 & 2.9 & 1647 & 101 \\
\hline dro8 & 1.11 & 1.46719 & 0.0071 & 0.282058 & 0.0270 & 0.095 & 61.0 & 0.00067 & 6.7 & 1133 & 17 & 0.3 & 3.1 & 1603 & 103 \\
\hline dro10a & 1.11 & 1.46728 & 0.0071 & 0.282167 & 0.0276 & 0.151 & 60.9 & 0.00110 & 6.3 & 1152 & 17 & 4.3 & 3.2 & 1476 & 107 \\
\hline dro10b & 0.99 & 1.4673 & 0.0074 & 0.282319 & 0.0276 & 0.082 & 60.9 & 0.00069 & 6.7 & 887 & 13 & 3.9 & 3.1 & 1257 & 105 \\
\hline dro11b & 0.95 & 1.4673 & 0.0070 & 0.281897 & 0.0279 & 0.091 & 60.9 & 0.00072 & 6.2 & 1558 & 24 & 4.3 & 3.4 & 1818 & 106 \\
\hline dro12a & 1.17 & 1.46723 & 0.0072 & 0.281791 & 0.0270 & 0.016 & 60.9 & 0.00016 & 6.1 & 552 & 8 & -22.2 & 2.9 & 1930 & 99 \\
\hline dro14b & 1.14 & 1.46726 & 0.0075 & 0.281450 & 0.0284 & 0.083 & 61.0 & 0.00060 & 7.3 & 1255 & 20 & -18.4 & 3.3 & 2398 & 107 \\
\hline dro17b & 1.08 & 1.46722 & 0.0069 & 0.282077 & 0.0287 & 0.216 & 61.1 & 0.00145 & 7.9 & 1263 & 21 & 3.3 & 3.4 & 1611 & 115 \\
\hline dro17c & 2.27 & 1.46728 & 0.0051 & 0.281994 & 0.0149 & 0.100 & 7.4 & 0.00062 & 5.3 & 1203 & 18 & -1.6 & 2.0 & 1739 & 61 \\
\hline dro16c & 3.17 & 1.46734 & 0.0058 & 0.282099 & 0.0149 & 0.105 & 8.2 & 0.00072 & 5.2 & 966 & 16 & -2.1 & 1.9 & 1551 & 57 \\
\hline dro21b & 2.24 & 1.46727 & 0.0050 & 0.282162 & 0.0151 & 0.129 & 7.1 & 0.00086 & 4.6 & 316 & 4 & -14.5 & 1.6 & 1473 & 58 \\
\hline dro22 & 2.60 & 1.46726 & 0.0050 & 0.281943 & 0.0158 & 0.064 & 7.0 & 0.00044 & 4.6 & 1176 & 18 & -2.6 & 2.0 & 1745 & 60 \\
\hline dro24b & 3.29 & 1.46721 & 0.0050 & 0.281979 & 0.0160 & 0.129 & 7.3 & 0.00085 & 5.4 & 1330 & 22 & 1.9 & 2.2 & 1716 & 62 \\
\hline dro31a & 2.33 & 1.46727 & 0.0052 & 0.282327 & 0.0167 & 0.052 & 7.4 & 0.00035 & 4.9 & 566 & 8 & -2.9 & 1.9 & 1236 & 63 \\
\hline dro32a & 1.93 & 1.46729 & 0.0052 & 0.282095 & 0.0155 & 0.067 & 7.1 & 0.00045 & 4.6 & 1082 & 16 & 0.6 & 1.9 & 1546 & 59 \\
\hline dro34a & 2.07 & 1.46714 & 0.0052 & 0.282171 & 0.0155 & 0.099 & 7.3 & 0.00074 & 4.6 & 523 & 8 & -9.6 & 1.8 & 1456 & 60 \\
\hline dro34b & 2.57 & 1.4672 & 0.0050 & 0.281628 & 0.0145 & 0.070 & 7.2 & 0.00052 & 4.6 & 1711 & 26 & -1.5 & 2.1 & 2161 & 55 \\
\hline dro36 & 2.46 & 1.46719 & 0.0051 & 0.281984 & 0.0157 & 0.069 & 7.1 & 0.00047 & 4.4 & 797 & 11 & -9.9 & 1.8 & 1692 & 59 \\
\hline dro35b & 2.55 & 1.46722 & 0.0056 & 0.282086 & 0.0154 & 0.083 & 7.7 & 0.00061 & 4.7 & 1137 & 17 & 1.5 & 2.0 & 1564 & 59 \\
\hline dro37b & 2.61 & 1.46723 & 0.0053 & 0.282108 & 0.0147 & 0.108 & 10.5 & 0.00075 & 9.4 & 869 & 12 & -4.0 & 1.8 & 1540 & 58 \\
\hline dro37c & 2.96 & 1.4672 & 0.0056 & 0.282061 & 0.0149 & 0.069 & 7.2 & 0.00048 & 5.4 & 1138 & 15 & 0.7 & 1.9 & 1592 & 56 \\
\hline dro65b & 2.32 & 1.46722 & 0.0053 & 0.281868 & 0.0157 & 0.129 & 7.8 & 0.00092 & 6.2 & 1560 & 21 & 3.1 & 2.1 & 1867 & 61 \\
\hline dro66c & 2.53 & 1.46721 & 0.0052 & 0.282557 & 0.0151 & 0.130 & 7.1 & 0.00088 & 4.4 & 306 & 4 & -0.8 & 1.6 & 943 & 59 \\
\hline dro64c & 2.59 & 1.46724 & 0.0054 & 0.281588 & 0.0151 & 0.091 & 7.0 & 0.00064 & 5.1 & 1707 & 24 & -3.1 & 2.1 & 2220 & 58 \\
\hline dro64e & 2.58 & 1.46731 & 0.0057 & 0.281900 & 0.0155 & 0.067 & 15.8 & 0.00044 & 10.7 & 587 & 7 & -17.6 & 1.7 & 1801 & 60 \\
\hline dro63e & 2.67 & 1.46716 & 0.0053 & 0.281950 & 0.0145 & 0.096 & 7.6 & 0.00067 & 5.6 & 1548 & 22 & 6.0 & 2.0 & 1746 & 56 \\
\hline dro61b & 2.51 & 1.46723 & 0.0051 & 0.282250 & 0.0158 & 0.042 & 7.5 & 0.00028 & 4.9 & 585 & 8 & -5.2 & 1.8 & 1335 & 59 \\
\hline dro61a & 2.74 & 1.4673 & 0.0042 & 0.282735 & 0.0129 & 0.208 & 12.0 & 0.00159 & 8.8 & 311 & 4 & 5.5 & 1.4 & 716 & 53 \\
\hline dro60b & 4.30 & 1.46722 & 0.0036 & 0.281870 & 0.0085 & 0.108 & 12.1 & 0.00073 & 8.5 & 1516 & 21 & 2.4 & 1.4 & 1854 & 35 \\
\hline dro59b & 3.71 & 1.46725 & 0.0036 & 0.281636 & 0.0097 & 0.163 & 12.0 & 0.00108 & 8.6 & 1620 & 22 & -3.9 & 1.6 & 2182 & 42 \\
\hline dro58a & 3.98 & 1.4672 & 0.0033 & 0.282427 & 0.0088 & 0.088 & 12.5 & 0.00057 & 8.7 & 581 & 7 & 0.9 & 1.1 & 1109 & 34 \\
\hline dro57 & 3.14 & 1.46726 & 0.0038 & 0.282118 & 0.0099 & 0.182 & 12.2 & 0.00118 & 9.0 & 1242 & 17 & 4.5 & 1.5 & 1544 & 42 \\
\hline dro56c & 2.76 & 1.46723 & 0.0034 & 0.280962 & 0.0113 & 0.092 & 13.1 & 0.00074 & 9.6 & 2633 & 42 & -3.9 & 2.3 & 3040 & 47 \\
\hline dro55a & 3.30 & 1.46715 & 0.0037 & 0.281684 & 0.0093 & 0.104 & 11.9 & 0.00077 & 8.3 & 1616 & 24 & -1.9 & 1.5 & 2101 & 38 \\
\hline dro55b & 2.27 & 1.46722 & 0.0046 & 0.281956 & 0.0108 & 0.094 & 11.9 & 0.00072 & 8.4 & 602 & 7 & -15.4 & 1.3 & 1740 & 43 \\
\hline
\end{tabular}




\begin{tabular}{|c|c|c|c|c|c|c|c|c|c|c|c|c|c|c|c|}
\hline dro54 & 3.44 & 1.4671 & 0.0034 & 0.282227 & 0.0108 & 0.194 & 11.9 & 0.00141 & 8.4 & 427 & 5 & -9.9 & 1.2 & 1406 & 46 \\
\hline dro52d & 2.06 & 1.46725 & 0.0053 & 0.282219 & 0.0165 & 0.112 & 15.9 & 0.00074 & 14.1 & 911 & 15 & 0.9 & 2.1 & 1392 & 66 \\
\hline dro51a & 2.39 & 1.46728 & 0.0045 & 0.282082 & 0.0111 & 0.089 & 12.0 & 0.00073 & 9.3 & 1104 & 15 & 0.5 & 1.5 & 1574 & 44 \\
\hline cap5 & 4.02 & 1.46728 & 0.0044 & 0.281720 & 0.0092 & 0.078 & 4.4 & 0.00034 & 3.3 & 1172 & 13 & -10.5 & 1.2 & 2031 & 34 \\
\hline cap6 & 3.61 & 1.46724 & 0.0061 & 0.282486 & 0.0092 & 0.311 & 3.0 & 0.00137 & 2.8 & 929 & 10 & 10.4 & 1.2 & 1052 & 36 \\
\hline cap7a & 2.92 & 1.46733 & 0.0030 & 0.281597 & 0.0104 & 0.127 & 4.6 & 0.00059 & 3.6 & 1808 & 22 & -0.4 & 1.6 & 2205 & 40 \\
\hline cap7b & 4.57 & 1.46718 & 0.0072 & 0.281636 & 0.0151 & 0.179 & 4.1 & 0.00081 & 3.9 & 1686 & 22 & -2.1 & 2.1 & 2168 & 58 \\
\hline cap9 & 4.75 & 1.46721 & 0.0054 & 0.282389 & 0.0147 & 0.131 & 4.7 & 0.00061 & 4.2 & 492 & 5 & -2.5 & 1.6 & 1162 & 56 \\
\hline cap11c & 4.64 & 1.46723 & 0.0053 & 0.281900 & 0.0145 & 0.111 & 4.1 & 0.00056 & 3.9 & 1153 & 13 & -4.7 & 1.8 & 1808 & 55 \\
\hline cap12 & 4.21 & 1.46725 & 0.0057 & 0.281970 & 0.0153 & 0.107 & 4.7 & 0.00051 & 4.2 & 1132 & 13 & -2.7 & 1.8 & 1713 & 58 \\
\hline cap23 & 3.63 & 1.46722 & 0.0075 & 0.282054 & 0.0160 & 0.082 & 4.1 & 0.00040 & 3.9 & 1166 & 13 & 1.1 & 1.9 & 1598 & 60 \\
\hline cap28 & 5.29 & 1.46729 & 0.0074 & 0.282124 & 0.0153 & 0.098 & 4.1 & 0.00050 & 3.9 & 1163 & 13 & 3.5 & 1.8 & 1509 & 58 \\
\hline cap30a & 4.92 & 1.4673 & 0.0065 & 0.281775 & 0.0161 & 0.108 & 4.4 & 0.00049 & 3.9 & 1660 & 39 & 2.7 & 2.5 & 1968 & 60 \\
\hline cap35 & 3.90 & 1.46722 & 0.0055 & 0.281643 & 0.0147 & 0.244 & 4.9 & 0.00116 & 4.5 & 1559 & 23 & -5.2 & 2.0 & 2178 & 58 \\
\hline cap37a & 3.90 & 1.46726 & 0.0060 & 0.282121 & 0.0159 & 0.124 & 4.2 & 0.00059 & 3.9 & 1146 & 13 & 2.9 & 1.9 & 1517 & 60 \\
\hline cap37b & 3.21 & 1.46721 & 0.0054 & 0.282123 & 0.0139 & 0.082 & 4.1 & 0.00039 & 3.9 & 755 & 13 & -5.9 & 1.7 & 1506 & 52 \\
\hline cap40a & 4.29 & 1.46723 & 0.0062 & 0.281816 & 0.0148 & 0.083 & 4.2 & 0.00040 & 3.9 & 556 & 6 & -21.3 & 1.6 & 1910 & 55 \\
\hline cap40b & 4.97 & 1.46724 & 0.0057 & 0.281574 & 0.0140 & 0.154 & 10.6 & 0.00069 & 9.6 & 1294 & 40 & -13.2 & 2.4 & 2242 & 56 \\
\hline cap41 & 3.38 & 1.46721 & 0.0059 & 0.281820 & 0.0142 & 0.175 & 4.6 & 0.00084 & 4.4 & 1653 & 19 & 3.6 & 1.9 & 1926 & 55 \\
\hline cap44b & 3.68 & 1.46727 & 0.0055 & 0.282264 & 0.0157 & 0.281 & 8.2 & 0.00129 & 7.7 & 304 & 3 & -11.3 & 1.7 & 1352 & 63 \\
\hline cap44e & 3.28 & 1.46724 & 0.0055 & 0.281581 & 0.0145 & 0.136 & 5.4 & 0.00063 & 5.2 & 1741 & 20 & -2.6 & 2.0 & 2230 & 55 \\
\hline cap44f & 3.09 & 1.46724 & 0.0054 & 0.281993 & 0.0150 & 0.088 & 5.2 & 0.00042 & 4.8 & 1165 & 13 & -1.1 & 1.8 & 1679 & 56 \\
\hline cap44h & 3.98 & 1.46721 & 0.0067 & 0.281217 & 0.0153 & 0.205 & 4.7 & 0.00095 & 4.8 & 1919 & 24 & -11.8 & 2.1 & 2726 & 60 \\
\hline cap48c & 3.67 & 1.46729 & 0.0063 & 0.282163 & 0.0143 & 0.109 & 4.1 & 0.00054 & 3.9 & 1156 & 13 & 4.7 & 1.7 & 1459 & 54 \\
\hline cap49 & 4.09 & 1.46731 & 0.0054 & 0.282365 & 0.0151 & 0.105 & 5.4 & 0.00050 & 4.9 & 588 & 6 & -1.1 & 1.7 & 1190 & 58 \\
\hline cap59a & 3.45 & 1.46728 & 0.0064 & 0.280767 & 0.0153 & 0.053 & 4.8 & 0.00028 & 4.3 & 2722 & 44 & -7.9 & 2.4 & 3253 & 56 \\
\hline cap59b & 4.20 & 1.46725 & 0.0053 & 0.281744 & 0.0155 & 0.150 & 4.5 & 0.00071 & 4.4 & 1768 & 21 & 3.8 & 2.1 & 2020 & 59 \\
\hline cap60c & 3.31 & 1.46727 & 0.0057 & 0.282214 & 0.0145 & 0.212 & 4.6 & 0.00098 & 4.3 & 1080 & 12 & 4.4 & 1.8 & 1408 & 57 \\
\hline cap62 & 3.12 & 1.46732 & 0.0056 & 0.282023 & 0.0162 & 0.113 & 4.2 & 0.00050 & 4.1 & 537 & 13 & -14.4 & 1.9 & 1643 & 61 \\
\hline cap64c & 2.45 & 1.46727 & 0.0070 & 0.282332 & 0.0144 & 0.199 & 5.6 & 0.00081 & 4.7 & 899 & 10 & 4.6 & 1.7 & 1244 & 56 \\
\hline cap65a & 3.06 & 1.46732 & 0.0056 & 0.282234 & 0.0147 & 0.053 & 4.2 & 0.00025 & 3.9 & 561 & 6 & -6.3 & 1.6 & 1355 & 55 \\
\hline cap67d & 3.72 & 1.46732 & 0.0069 & 0.281800 & 0.0163 & 0.080 & 7.3 & 0.00037 & 7.2 & 604 & 7 & -20.7 & 1.8 & 1929 & 61 \\
\hline cap69a & 2.48 & 1.46723 & 0.0064 & 0.282223 & 0.0159 & 0.081 & 4.1 & 0.00040 & 3.9 & 1114 & 13 & 5.9 & 1.9 & 1375 & 60 \\
\hline cap70b & 3.15 & 1.46725 & 0.0064 & 0.282284 & 0.0151 & 0.160 & 5.9 & 0.00077 & 5.8 & 811 & 9 & 0.9 & 1.7 & 1307 & 59 \\
\hline cap72 & 2.45 & 1.46728 & 0.0071 & 0.282116 & 0.0169 & 0.143 & 4.1 & 0.00068 & 3.9 & 1093 & 17 & 1.4 & 2.1 & 1527 & 64 \\
\hline cap73c & 2.53 & 1.46732 & 0.0061 & 0.282104 & 0.0159 & 0.087 & 4.1 & 0.00041 & 3.9 & 1201 & 24 & 4.2 & 2.1 & 1533 & 60 \\
\hline cap75b & 3.17 & 1.4673 & 0.0066 & 0.281559 & 0.0171 & 0.089 & 4.8 & 0.00043 & 4.7 & 1786 & 28 & -2.1 & 2.4 & 2246 & 64 \\
\hline cap84a & 2.95 & 1.46729 & 0.0057 & 0.281761 & 0.0147 & 0.167 & 4.4 & 0.00080 & 4.2 & 1657 & 26 & 1.7 & 2.1 & 2003 & 56 \\
\hline cap81a & 3.13 & 1.46721 & 0.0064 & 0.282067 & 0.0150 & 0.109 & 4.2 & 0.00049 & 3.9 & 1189 & 18 & 2.1 & 1.9 & 1585 & 57 \\
\hline cap83b & 3.31 & 1.46716 & 0.0064 & 0.281927 & 0.0151 & 0.115 & 4.2 & 0.00055 & 3.9 & 1155 & 17 & -3.7 & 1.9 & 1772 & 57 \\
\hline cap82b & 3.00 & 1.46718 & 0.0060 & 0.282101 & 0.0150 & 0.081 & 4.1 & 0.00040 & 3.9 & 1191 & 18 & 3.4 & 1.9 & 1536 & 56 \\
\hline cap104 & 3.24 & 1.46728 & 0.0057 & 0.282161 & 0.0151 & 0.098 & 6.4 & 0.00051 & 6.9 & 474 & 7 & -11.0 & 1.7 & 1461 & 58 \\
\hline
\end{tabular}




\begin{tabular}{|c|c|c|c|c|c|c|c|c|c|c|c|c|c|c|c|}
\hline cap103a & 3.03 & 1.46731 & 0.0051 & 0.282257 & 0.0151 & 0.179 & 5.3 & 0.00086 & 4.8 & 304 & 4 & -11.5 & 1.6 & 1346 & 59 \\
\hline cap54a & 3.48 & 1.46725 & 0.0063 & 0.282075 & 0.0144 & 0.102 & 4.5 & 0.00049 & 4.1 & 1052 & 371 & -0.8 & 9.9 & 1574 & 54 \\
\hline сус3 & 4.38 & 1.46736 & 0.0046 & 0.28194 & 0.0090 & 0.154 & 3.5 & 0.00093 & 3.2 & 1533 & 24 & 5.1 & 1.5 & 1768 & 35 \\
\hline сус5 & 4.40 & 1.46728 & 0.0052 & 0.28172 & 0.0081 & 0.129 & 2.6 & 0.00072 & 1.9 & 1662 & 22 & 0.6 & 1.3 & 2046 & 31 \\
\hline cyc7a & 4.67 & 1.46727 & 0.0052 & 0.28172 & 0.0084 & 0.119 & 3.6 & 0.00069 & 3.4 & 1740 & 24 & 2.2 & 1.4 & 2052 & 32 \\
\hline сус9 & 4.41 & 1.46725 & 0.0066 & 0.28163 & 0.0095 & 0.131 & 3.8 & 0.00068 & 3.1 & 1826 & 25 & 1.0 & 1.6 & 2171 & 36 \\
\hline cyc10b & 4.07 & 1.46718 & 0.0054 & 0.28219 & 0.0110 & 0.342 & 2.8 & 0.00195 & 2.5 & 1137 & 15 & 4.3 & 1.5 & 1471 & 45 \\
\hline cyc14b & 3.94 & 1.46726 & 0.0052 & 0.28106 & 0.0100 & 0.164 & 2.5 & 0.00090 & 2.3 & 2252 & 31 & -9.7 & 1.7 & 2931 & 38 \\
\hline сус15a & 3.95 & 1.46733 & 0.0059 & 0.28214 & 0.0100 & 0.100 & 2.4 & 0.00055 & 2.1 & 1177 & 15 & 4.3 & 1.4 & 1492 & 38 \\
\hline сус20a & 3.49 & 1.46725 & 0.0069 & 0.28166 & 0.0093 & 0.099 & 3.9 & 0.00055 & 3.6 & 1758 & 24 & 0.9 & 1.5 & 2116 & 35 \\
\hline сус21 & 3.40 & 1.46724 & 0.0067 & 0.28212 & 0.0088 & 0.100 & 2.4 & 0.00055 & 1.9 & 1190 & 16 & 4.0 & 1.3 & 1513 & 33 \\
\hline cyc34b & 4.20 & 1.46721 & 0.0055 & 0.28230 & 0.0081 & 0.108 & 3.4 & 0.00056 & 2.3 & 585 & 7 & -3.5 & 1.0 & 1278 & 31 \\
\hline сус57b & 4.41 & 1.46734 & 0.0052 & 0.28149 & 0.0095 & 0.208 & 2.7 & 0.00115 & 2.3 & 1781 & 25 & -5.5 & 1.5 & 2379 & 37 \\
\hline сус58b & 3.24 & 1.46722 & 0.0059 & 0.28168 & 0.0088 & 0.059 & 2.5 & 0.00030 & 1.9 & 478 & 6 & -27.7 & 1.0 & 2079 & 33 \\
\hline сус91b & 3.71 & 1.46730 & 0.0057 & 0.28193 & 0.0086 & 0.182 & 2.6 & 0.00100 & 2.0 & 1551 & 21 & 4.9 & 1.4 & 1794 & 33 \\
\hline сус93 & 3.71 & 1.46730 & 0.0051 & 0.28249 & 0.0095 & 0.298 & 2.7 & 0.00166 & 2.6 & 353 & 4 & -2.3 & 1.1 & 1054 & 38 \\
\hline сус85 & 3.02 & 1.46725 & 0.0054 & 0.28133 & 0.0098 & 0.110 & 2.4 & 0.00060 & 1.9 & 1355 & 19 & -20.2 & 1.4 & 2551 & 36 \\
\hline сус84a & 2.25 & 1.46721 & 0.0069 & 0.28210 & 0.0113 & 0.235 & 2.9 & 0.00132 & 2.9 & 308 & 4 & -17.1 & 1.2 & 1576 & 45 \\
\hline сус82a & 2.98 & 1.46725 & 0.0058 & 0.28187 & 0.0105 & 0.213 & 2.4 & 0.00121 & 2.3 & 1607 & 22 & 3.8 & 1.6 & 1883 & 41 \\
\hline cyc49c & 3.64 & 1.46716 & 0.0056 & 0.28218 & 0.0095 & 0.101 & 2.8 & 0.00066 & 2.8 & 1049 & 15 & 2.7 & 1.3 & 1443 & 36 \\
\hline cyc49b & 3.24 & 1.46722 & 0.0048 & 0.28176 & 0.0093 & 0.111 & 3.8 & 0.00063 & 2.7 & 537 & 7 & -23.7 & 1.1 & 1992 & 35 \\
\hline cyc47 & 3.86 & 1.46718 & 0.0047 & 0.28212 & 0.0079 & 0.070 & 2.5 & 0.00040 & 1.9 & 1173 & 15 & 3.6 & 1.2 & 1512 & 30 \\
\hline cyc45b & 3.59 & 1.46718 & 0.0040 & 0.28229 & 0.0078 & 0.117 & 2.7 & 0.00065 & 2.1 & 712 & 9 & -1.2 & 1.0 & 1300 & 30 \\
\hline сус44a & 3.96 & 1.46725 & 0.0047 & 0.28170 & 0.0081 & 0.094 & 2.6 & 0.00049 & 1.9 & 1337 & 21 & -7.6 & 1.3 & 2070 & 30 \\
\hline сус41 & 3.11 & 1.46728 & 0.0050 & 0.28227 & 0.0108 & 0.287 & 3.8 & 0.00160 & 3.6 & 315 & 4 & -10.8 & 1.2 & 1350 & 44 \\
\hline сус $25 a$ & 3.34 & 1.46733 & 0.0055 & 0.28225 & 0.0100 & 0.188 & 2.4 & 0.00114 & 2.2 & 354 & 4 & -10.7 & 1.1 & 1370 & 39 \\
\hline cyc25b & 3.49 & 1.46730 & 0.0043 & 0.28172 & 0.0082 & 0.106 & 4.3 & 0.00062 & 4.2 & 1663 & 23 & 0.4 & 1.4 & 2052 & 32 \\
\hline сус38b & 3.33 & 1.46721 & 0.0045 & 0.28271 & 0.0095 & 0.210 & 2.7 & 0.00123 & 2.3 & 327 & 4 & 4.9 & 1.0 & 749 & 37 \\
\hline сус39 & 3.33 & 1.46725 & 0.0048 & 0.28173 & 0.0093 & 0.010 & 2.9 & 0.00004 & 2.2 & 587 & 7 & -23.5 & 1.1 & 2005 & 34 \\
\hline cyc37b & 3.49 & 1.46729 & 0.0048 & 0.28189 & 0.0103 & 0.184 & 2.6 & 0.00110 & 2.0 & 1579 & 22 & 4.2 & 1.5 & 1842 & 40 \\
\hline сус60с & 2.87 & 1.46728 & 0.0051 & 0.28235 & 0.0097 & 0.177 & 7.2 & 0.00104 & 5.4 & 934 & 13 & 5.8 & 1.3 & 1230 & 39 \\
\hline сус59a & 3.42 & 1.46727 & 0.0055 & 0.28171 & 0.0098 & 0.128 & 2.3 & 0.00074 & 2.0 & 1793 & 24 & 3.1 & 1.6 & 2066 & 37 \\
\hline сус97а & 3.41 & 1.46726 & 0.0044 & 0.28159 & 0.0091 & 0.101 & 2.8 & 0.00053 & 2.0 & 1748 & 24 & -1.8 & 1.5 & 2207 & 34 \\
\hline сус71b & 2.83 & 1.46724 & 0.0056 & 0.28212 & 0.0090 & 0.224 & 2.9 & 0.00128 & 2.1 & 1090 & 14 & 1.2 & 1.2 & 1539 & 36 \\
\hline сус72 & 3.74 & 1.46737 & 0.0063 & 0.28196 & 0.0100 & 0.134 & 2.5 & 0.00079 & 1.9 & 1576 & 22 & 7.1 & 1.5 & 1732 & 38 \\
\hline сус $109 \mathrm{e}$ & 3.89 & 1.46726 & 0.0048 & 0.28151 & 0.0084 & 0.198 & 3.1 & 0.00106 & 2.4 & 1829 & 26 & -3.5 & 1.5 & 2345 & 33 \\
\hline сус118a & 4.47 & 1.46727 & 0.0047 & 0.28179 & 0.0086 & 0.463 & 2.5 & 0.00217 & 2.0 & 1290 & 20 & -6.9 & 1.3 & 2037 & 36 \\
\hline cyc118b & 3.02 & 1.46726 & 0.0044 & 0.28231 & 0.0100 & 0.176 & 2.6 & 0.00096 & 2.5 & 409 & 5 & -7.2 & 1.1 & 1276 & 39 \\
\hline cyc1a & 3.64 & 1.46727 & 0.0067 & 0.28099 & 0.0103 & 0.255 & 2.6 & 0.00135 & 2.6 & 2837 & 43 & 0.8 & 2.1 & 3047 & 41 \\
\hline
\end{tabular}

All data are normalised to JMC475 $176 \mathrm{Hf} / 177 \mathrm{Hf}=0.282160$ and $91500176 \mathrm{Lu} / 177 \mathrm{Hf}=0.000311$ run at the time of analysis. 
2

3

4

5

6

8

Laser ablation of 91500 gave $176 \mathrm{Hf} / 177 \mathrm{Hf}=0.282296-0.282325$ for the various sessions over the period of analysis. Uncertainties for reproducibility of $91500178 \mathrm{Hf} / 177 \mathrm{Hf}, 176 \mathrm{Hf} / 177 \mathrm{Hf}$ and $176 \mathrm{Lu} / 177 \mathrm{Hf}$ are propagated into the sample data uncertainties. Epsilon $\mathrm{Hf}$ is calculated after correction for decay of $176 \mathrm{Lu}$

Epsilon $\mathrm{Hf}$ and Model age uncertainties are calculated by calculating through the outer error limits. 